\title{
Gemma
}

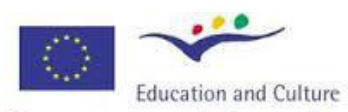

Erasmus Mundus

\section{Transmigración centroamericana.}

Motivaciones, riesgos y estrategias en el trayecto hacia un sueño.

\author{
Margarita Trejo Velasco
}

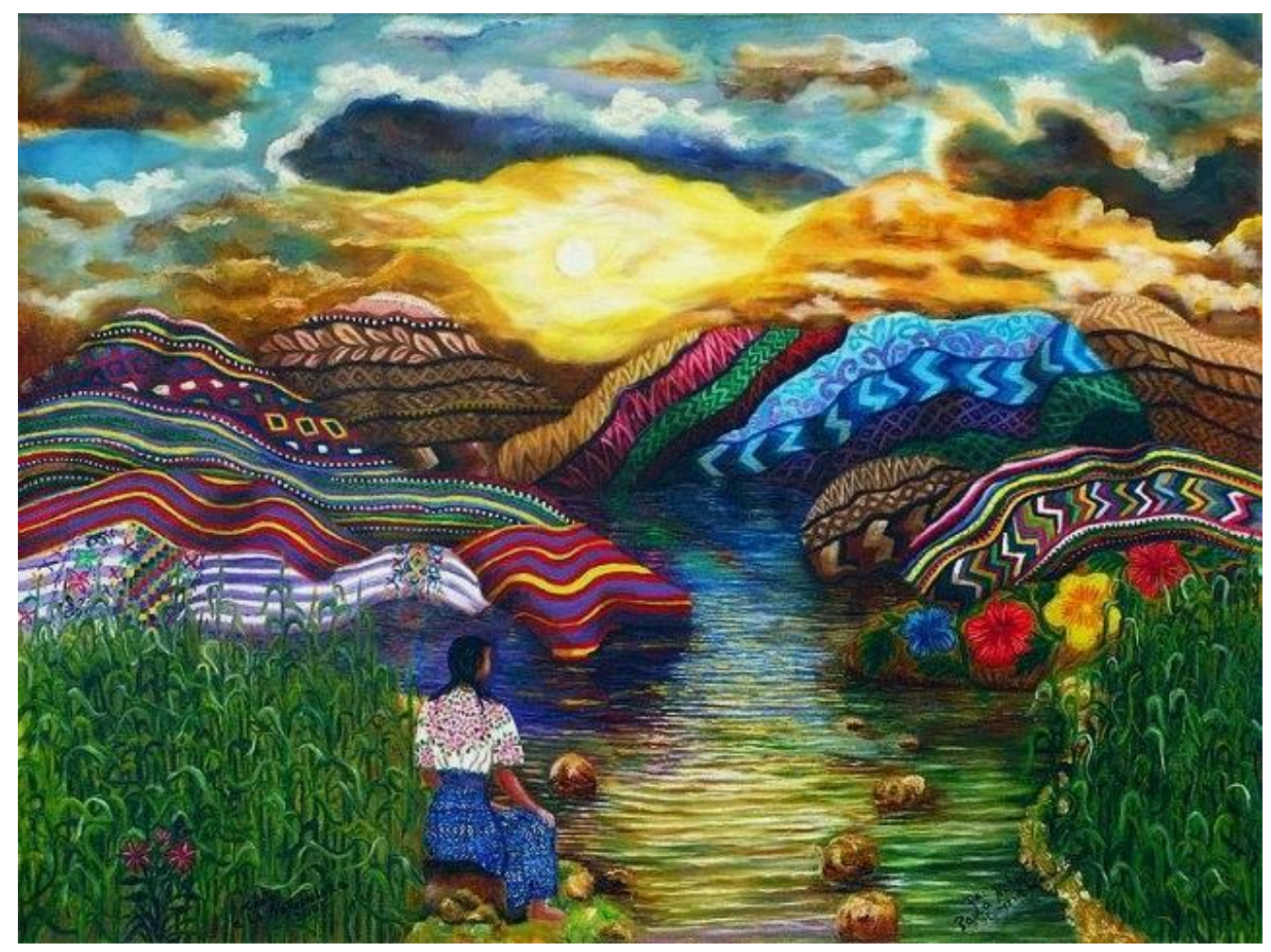

Granada, España. 2015

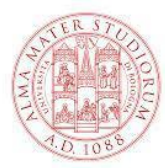



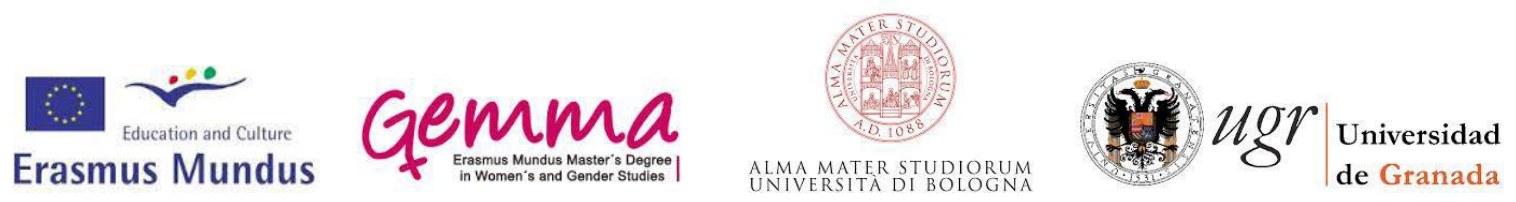

\title{
Transmigración centroamericana
}

\section{Motivaciones, riesgos y estrategias en el trayecto hacia un sueño}

\author{
Margarita Trejo Velasco
}

\author{
Directora \\ Carmen Gregorio Gil \\ Profesora Titular de Antropología social \\ Directora del Departamento de Antropología Social \\ Universidad de Granada
}

Directora de apoyo

Elena Musiani

Tutor didattico

Assegnista di ricerca

Scuola di Lingue e Letterature, Traduzione e Interpretazione

Universitá di Bologna

Firma de aprobación

Granada, España. 2015

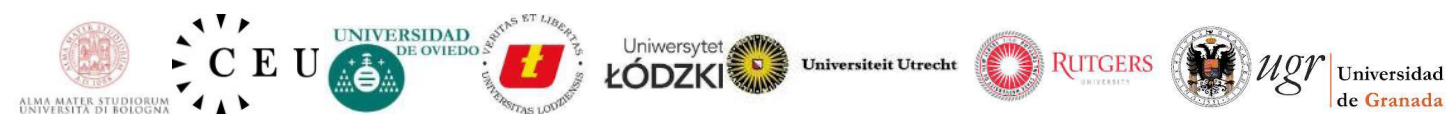




\section{Resumen}

La falta de acceso a oportunidades, el inequitativo ambiente social, político y cultural en distintas regiones del mundo aunado a difíciles circunstancias climáticas, son algunas de las causas de la movilidad humana hacia la búsqueda de mejoras en su calidad de vida en otros espacios. Así como también la curiosidad por experimentar algo diferente, el acercamiento a culturas diversas, el deseo por conocer distintas maneras de vivir, son otras razones por las cuales se plantea la posibilidad de moverse de lugar.

Así como las causas de la movilidad son diversas, los impactos, significados, riesgos y retos también son distintos para cada persona o colectivo.

Tomando al género como herramienta de análisis, entendiéndolo como una categoría de diferenciación social, una construcción cultural, dinámica y contextualizada que da cuenta de múltiples y simultáneos factores de discriminación que estructuran espacios y relaciones de poder, pretendo dar cuenta de cómo estos principios se articulan en el trayecto migratorio de personas transmigrantes de Centroamérica, que deciden moverse de lugar atravesando el territorio mexicano, en exploración y demanda de una vida mejor vivible. Mediante una aproximación a sus subjetividades, abordando las razones que se plantean para hacerlo, los riesgos que vivencian o consideran posibles durante el trayecto, así como las estrategias que ocupan para llevar a cabo el viaje y enfrentar dichos riesgos, mostrando su capacidad de acción y decisión.

\section{Riassunto}

La mancanza di accesso alle opportunità, l'ambiente sociale, politico e culturale iniquo in diverse regioni del mondo, insieme con le condizioni climatiche difficili, sono alcune delle cause della mobilità umana in cerca di una migliore qualità di vita in altri regioni. Inoltre, la curiosità di sperimentare qualcosa di diverso, l'approccio alle diverse culture, il desiderio di conoscere diversi modi di vivere, sono altri motivi per cui si pensa alla possibilità di trasferirsi.

Poiché le cause sono diverse, anche le reazioni, i significati, i rischi e le sfide sono diversi per ogni persona o gruppo.

Considerando il genere come strumento analitico, inteso come categoria di differenziazione sociale, una costruzione culturale, dinamica e contestualizzata che mostra molteplici e simultanei fattori discriminanti, che strutturano spazi e relazioni di potere. Ho intenzione di spiegare come questi principi si articolano nel percorso migratorio di persone trasmigranti da Centroamerica, che decidono di emigrare attraverso il territorio messicano alla ricerca e richiesta di una vita migliore. Tutto ciò verrà analizzato prendendo in considerazione la soggettività delle persone, cercando le motivazioni che li portano a tale decisione, i rischi che possono affrontare e le strategie utilizzate per affrontare il viaggio e tali rischi, mostrando la sua capacitá d'azione e di decisione. 


\section{Agradecimientos}

Este trabajo es producto de la colaboración de muchas personas, libros, imágenes, sueños, recuerdos, viajes, feminismos que van transformando mi visión y estancia en el mundo.

Agradezco a mi mamá, quien con amor, paciencia, confianza, palabras de aliento y oraciones va siempre conmigo, en cada lugar y en cada proyecto que emprendo; el pensar en ti me inspira serenidad y ganas de seguir luchando.

A Sandri, mi hermana, con tu amor y ejemplo de esmero y dedicación me motivas a ser firme, gracias por acompañarme. Las tres unidas, este logro $i$ Va por ustedes!!

A las personas transmigrantes INFINITAS GRACIAS por compartir su valentía, historias, silencios, sonrisas, tiempo y vivencias conmigo. A Flor María, el personal del albergue “Belén” y “El Buen Pastor” ¡Su labor es grandiosa! Gracias por su generosidad.

Agradezco infinitamente a Carmen, mi directora de tesis, porque tu valiosa colaboración me brinda confianza en este trabajo y tus aportes me motivan a ver en la academia un espacio de grandes transformaciones. Gracias por acompañarme en este viaje.

A Elena, corelatrice di questa tesi, grazie mille per la tua saggezza e solidarietá in questo lavoro, per essere stata un’altra compagna costante di questo viaggio.

Así como a todo el profesorado y alumnado que he conocido en este recorrido, con su sabiduría han ido nutriendo mi experiencia. Al consorcio GEMMA gracias por su confianza y aceptación en este máster, representa para mí uno de los mayores logros en mi vida.

A Lupita por estar conmigo siempre, con tus palabras, sonrisas y luz me transmites calma y confianza en mí misma y en lo que me rodea.

A Samantha por tu cariño, tiempo y recomendaciones, cada uno de mis logros tiene una parte tuya.

A mi familia y amistades en México y en diversas partes del mundo, que con sus pensamientos, buenos deseos y cariño me acompañan en la distancia.

A Ilaria sei la mia hermana del cuore, a tutta la famiglia Emiliani perché grazie a voi, Bologna é per me la mia seconda casa.

A mis colegas, Diana, Rut, Ivona, Isabel, Michele, Joanne, Judith, Julia, Claudia, Dresda, Meli, Chabelita, Andrea, Silvi, Paula y a todas las GEMMAS que se han cruzado en mí camino, gracias por compartir momentos especiales. A Tatiana y Paola, gracias por mostrarme el camino hacia los feminismos.

A mi papá, mi compañero ¡iVa también por ti!! 


\section{Índice}

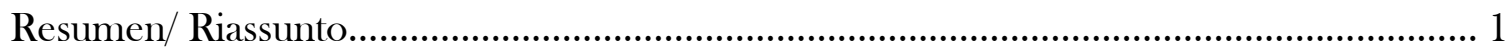

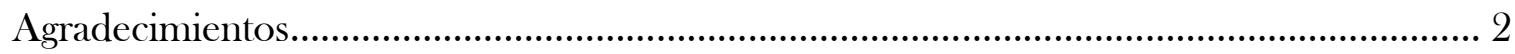

Introducción............................................................................................................ 5

CAPÍTULO 1. PUNTO DE PARTIDA.............................................................. 7

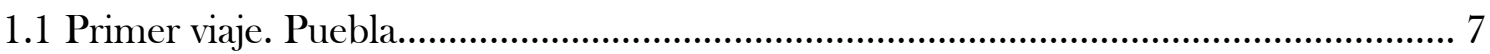

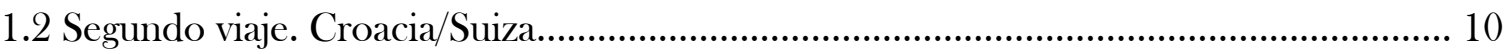

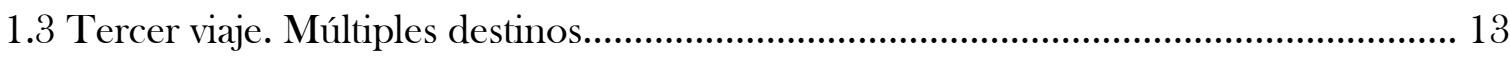

1.4 Cuarto viaje. Bologna/ Granada.......................................................................... 15

1.5 Invitación a un nuevo viaje por medio de los feminismos................................................ 16

CAPÍTULO 2. PLANEACIÓN DEL VIAJE.......................................................... 22

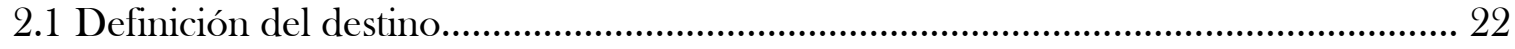

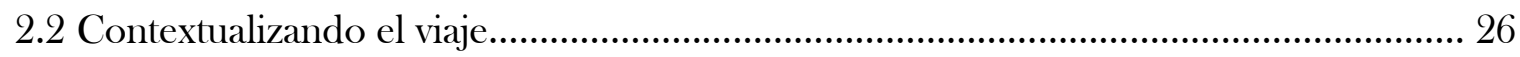

2.2.1 Breve acercamiento histórico a la transmigración centroamericana............................ 26

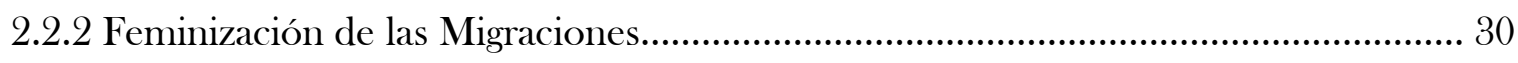

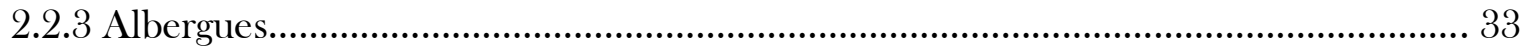

a) Albergue "El Buen Pastor"..................................................................................... 34

b) Casa del Migrante “Sin Fronteras (Mi’n Npon B’aj)”. Tecún Umán........................ 35

c) Albergue "Belén"..................................................................................................... 36

CAPÍTULO 3. HABITANDO EL VIAJE.......................................................... 40

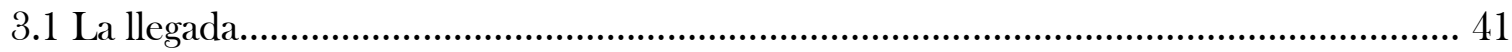

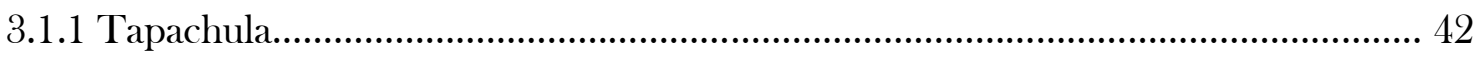

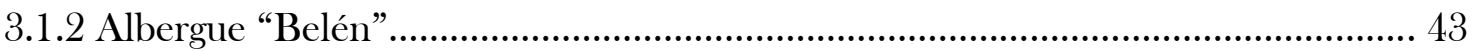

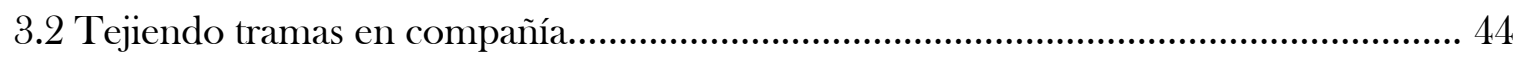

3.2.1 Historia de Armando.................................................................................. 44

3.2.2 Trama de Daylin........................................................................................... 49

3.2.3 Historia de Karla.......................................................................................... 55

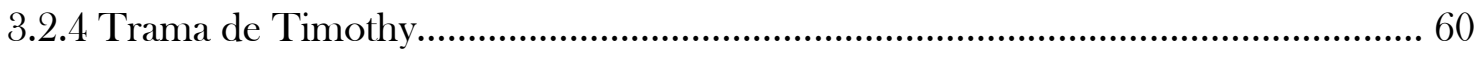

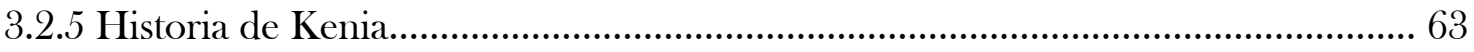

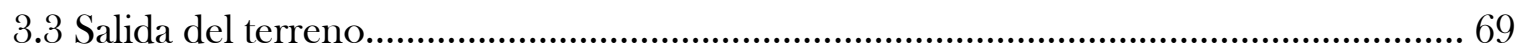




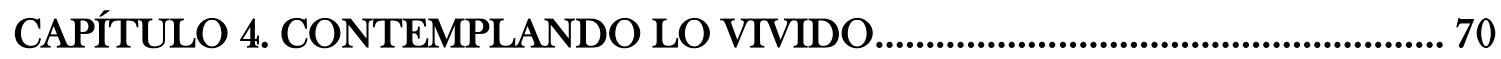

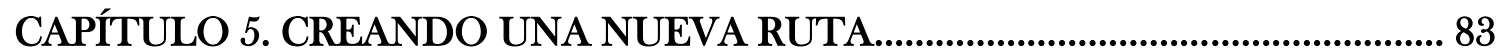

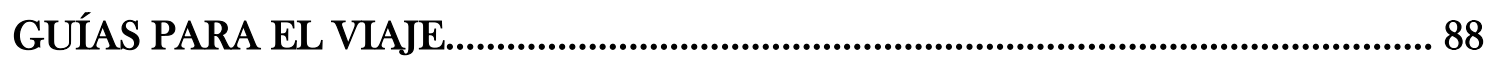

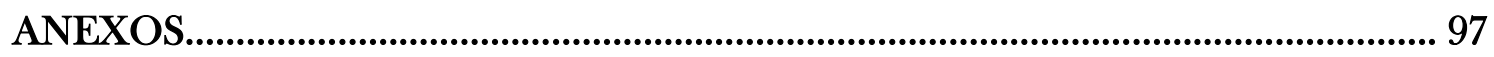

Anexo I. Guías para la recopilación de información.............................................................. 97

Anexo II. Mis propias estrategias para habitar el viaje.......................................................... 103

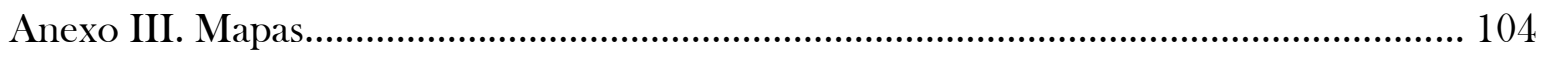

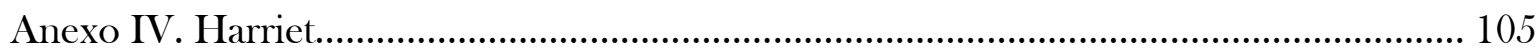




\section{Introducción}

"El río se llena por arroyos pequeños" (Proverbio africano)

Para comenzar, quiero explicar los títulos que he elegido para cada capítulo, ya que me parece importante compartir tanto los resultados de este trabajo como algunos de los elementos en el proceso de elaboración del mismo.

Cuando inicié a escribir esta tesis, lo hice pensando ¿Cuando viajo qué pasos sigo? La respuesta a esta pregunta me ayudó a crear la estructura de este trabajo, además con esto propongo una lectura en la que el viaje sea el punto de referencia; es por ello que utilizo "títulos viajeros" haciendo uso de categorías EMIC", sin embargo, explicaré el tema a abordar al inicio de cada capítulo.

Tomando en cuenta las propuestas de feministas como Adrienne Rich ${ }^{2}$, Carmen Gregorio Gil $^{3}$, Donna Haraway ${ }^{4}$, Sandra Harding ${ }^{5}$ y Susan Stanford Friedman ${ }^{6}$, entre otras, quienes hablan del conocimiento situado y de la política de localización de quien investiga como puntos de partida para realizar cualquier tipo de colaboración, considerando la propia subjetividad como elemento ineludible en todo el proceso y, haciendo hincapié en la

\footnotetext{
${ }^{1}$ Las categorías EMIC desde el enfoque etnográfico de Matilde Fernández se utilizan dentro de los trabajos en su interpretación de los fenómenos estudiados como categorías conscientes o inconscientes que son significativas para la persona o colectividad que proporciona los datos.

Matilde Fernández Montes, "Sujetos como objeto de estudio," en Dilemas éticos en antropología: Las entretelas del trabajo de campo etnográfico, editado por Margarita del Olmo (Madrid: Trotta, 2010), 303314.

${ }^{2}$ Adrienne Rich, "Notes toward a Politics of Location". En Feminist Postcolonial Theory: A Reader, editado por Reina Lewis and Sara Mills (NY: Edinburgh University Press, 2003), 29-42.

${ }^{3}$ Carmen Gregorio Gil, “Tensiones conceptuales entre la relación género y migraciones”. Papers, 97/3, (2012): 569-590.

${ }^{4}$ Donna Haraway, "Situated Knowledges: The Science Question in Feminism and the Privilege of Partial Perspective". Feminist Studies 14, no. 3. (Autumn, 1988): 575-599.

${ }^{5}$ Sandra Harding, "Is There a Feminist Method?" en Feminism and Science, editado por Nancy Tuana (Bloomington/ Indianapolis: Indiana University Press, 1987), 18-32.

${ }^{6}$ Susan Stanford Friedman, "Locational Feminism: Gender, Cultural Geographies, and Geopolitical Literacy". En Feminist Locations: Local and Global, Theory and Practice, ed. Marianne Dekoven (USA: Rutgers University Press, 2001), 13-36.
} 
importancia de la motivación hacia el tema a trabajar con el cual estaremos en constante diálogo, he decidido abordar el tema de la diversidad en la transmigración centroamericana, indagando en las subjetividades de algunas personas que deciden realizar este viaje a sabiendas de los posibles riesgos que se pueden presentar, desarrollando y apropiándose de estrategias para llevar a cabo dicho viaje hacia diversas metas, hacia diversos sueños.

Múltiples circunstancias hacen que el acto de migrar sea uno de los fenómenos globales de mayor relevancia en estos últimos años. En lo personal, el hecho de migrar tiene un significado muy importante, me ha ido construyendo, es una de las razones por las cuales me encuentro en el espacio europeo estudiando este máster y, a su vez el motivo que me ha llevado a elegir tanto el tema como la metodología para llevar a cabo este trabajo.

'Viajar -como las migraciones, que muchas/os de nosotras/os, de maneras muy diferentes, hemos experimentado- nos une con lo que Homi Bhabha llama "reuniones de exiliadas/os, emigradas/os y refugiadas/os, reuniones en el borde de las culturas 'extranjeras'... la recolección en el medio de vida, media luz de lenguas extranjeras... reuniendo el pasado con el ritual del renacimiento"

Mediante una breve autobiografía tensionada entre la conciencia del presente y el recogimiento del pasado, buscaré plasmar mi interés por este tema de estudio, la posición desde la cual hablo y el compromiso que este trabajo de tesis tiene para mí, esto desde algunos de los viajes más significativos que he realizado.

Haciendo uso del proverbio africano como metáfora, quiero mostrar los arroyos que han desembocado en este río, en este nuevo viaje.

\footnotetext{
${ }^{7}$ Citando el texto original 'Travel - like the migrations which so many of us, in very different ways, have experienced- join us with what Homi Bhabha calls "gatherings of exiles and émigrès and refugees, gatherings on the edge of 'foreign' cultures...gathering in the half life, half light of foreign tongues...gathering the past in ritual of revival'.

Laurent Dubois, “Man's Darkest Hours: Maleness, Travel and Anthropology', En Women Writing Culture, Coords. Ruth Behar y Deborah Gordon (Berkeley y London: University of California Press, 1995), 247 [Traducción mía].
} 


\section{Capítulo I. Punto de Partida}

"La lectura hace a la persona completa; ; la conversación, ágil, y el escribir, preciso" (Francis Bacon)

\subsection{Primer viaje. Puebla, México}

El interés que se ha despertado en mí por el fenómeno de la migración lleva varios años presente, surge de mi propia situación como mujer en movilidad en diversas etapas de mi vida, cruzando fronteras ${ }^{9}$ continuamente, percibida como la "otra” en diversos espacios, como "la mexicana" en algunos lugares. Indiscutiblemente mi mirada se ha enfocado en las personas que como yo, han decidido moverse de lugar enfrentándose a retos, algunos contemplados y otros completamente desconocidos.

Mi primer viaje, siendo una mujer de 17 años, heterosexual, sin diversidad funcional, soltera, de clase media, perteneciente a una familia fuertemente católica, la mayor de dos hermanas y originaria de San Cristóbal de las Casas, una ciudad pequeña y pintoresca en lo alto de las montañas del estado de Chiapas, al sur de México; lo realicé motivada por mi padre para ir en busca de la universidad y el lugar, en los cuales emprendería una nueva etapa como estudiante.

Esto representó para mí el inicio de la “independencia”, puesto que el viaje de dos semanas lo realizaría sola en diversos puntos del país y, aunque en varios de esos lugares encontré a familiares que me acompañaron, yo marcaba la ruta.

Decidí quedarme en Puebla, ciudad ubicada en el centro del país, debido a que la ciudad me encantó, la universidad tiene gran reconocimiento académico y además vivían familiares con quienes mantenía una buena relación y podía compartir el espacio para vivir.

\footnotetext{
${ }^{8}$ [énfasis mío] Modificado de la frase original que dice "la lectura hace al 'hombre completo'...”.

${ }^{9}$ Uso el término Fronteras desde mi entendimiento de las aportaciones de la chicana Gloria Anzaldúa, quien estudia las barreras o fronteras sociales, culturales, naturales, simbólicas/semióticas que separan y construyen la identidad desde los márgenes.

Gloria Anzaldúa, Borderlands/La Frontera: The New Mestiza (San Francisco: Aunt Lute, 1987).

A su vez tomo en cuenta las dimensiones establecidas por Carmen Gregorio, siendo éstas: las procreativas, étnico-culturales, sexuales y reproductivas, como demarcación entre las representaciones y las lógicas de inclusión y exclusión de un "nosotras/os" frente a "otras/os".

Carmen Gregorio Gil, "Mujeres inmigrantes: Colonizando sus cuerpos mediante fronteras procreativas, étnico-culturales, sexuales y reproductivas”, Viento sur: por una izquierda alternativa, no. 104 (2009): $42-54$.
} 
Por medio de una beca y el apoyo económico-moral de mi mamá, presenté el examen de admisión, el cual aprobé; mi papá por su parte se rehúso a apoyarme, parecía muy irónico que siendo él quien me motivara previamente a descubrir otros lugares me negará su ayuda, ahora entiendo que su reacción se debió a problemas económicos, hecho por el cual mantener una carrera universitaria en una ciudad más costosa, le parecía un disparate.

Mi mamá decidió apoyarme en todo, aún con su gran pesar por separarnos y enfrentando a mi papá. Demostró una fuerza enorme e inspiradora, la cual evoco con el ensayo de Alice Walker $^{10}$, en el cual menciona la importancia de crear una genealogía de quienes han sido nuestras madres en sentido no solo biológico sino simbólico, es decir, de quienes han sido nuestras inspiraciones y portadoras de avances y transformaciones.

Viví 5 años en Puebla. Estudiando la carrera de psicología junto a estudiantes de diversos estados de la república, me sentía como "la chiapaneca ${ }^{11}$ y chiquita”, ya que era de las más pequeñas de edad y estatura, quien usaba un "cantadito" ${ }^{12}$ y palabras distintas al hablar; otra cosa que me extrañaba mucho era que me llamaran "blanquita”, ya que en casa he sido considerada de las más morenas de la familia, "negrita” para mi mamá, por eso era raro escuchar nombrarme de la manera opuesta. Comencé a darme cuenta como las clasificaciones corporales te colocan en fluctuaciones de privilegios-desventajas en los contextos por los que te muevas, como el poder se ejerce en función de la corporalidad; comencé a jugar con el mismo, remarcando esas características diferenciales cuando me convenía, tratando de ocultarlas cuando creía que debía. En línea con algunas ideas de Foucault $^{13}$ y Mohanty $^{14}$ lo entiendo ahora como una multiplicidad de poderes que se ejercen en el sistema social considerando al cuerpo como artificio, el cual se construye y funciona a partir de los efectos de dichos poderes.

\footnotetext{
10 Alice Walker, “In Search of Our Mothers' Gardens,” en Within the circle: an anthology of African American literary criticism from the Harlem Renaissance to the present, Angelyn Mitchell (Durham and London: Duke University Press, 1994), 401-409.

11 “chiapaneca/o" es el gentilicio para nombrar a las personas originarias del estado de Chiapas.

12 "cantadito" es la forma de describir la manera de hablar marcando entonaciones distintas.

${ }^{13}$ Michael Foucault, Vigilar y castigar (Argentina: Siglo veintiuno editores, 2002).

${ }^{14}$ Chandra Mohanty, “Under Western Eyes,” Signs 28, no. 2 (2003): 499-535.
} 
El grupo de amistades con quien convivía me ayudo a que la sensación de sentirme ajena a la “cultura poblana"15 se disipara rápidamente. Al finalizar la carrera, tenía muchas dudas de dónde desarrollarme como psicóloga, incertidumbre compartida con varias personas, entre ellas mi amiga Diana, quien buscaba los medios para ir a Europa. Decidí unirme a esa búsqueda e inscribirme al programa au pair ${ }^{16}$. Tuve la oferta de ir a Zagreb, Croacia, con una familia conformada por Susana de Guatemala, Francesco de Suiza, Diego de 3 años y Valeria de 9 meses.

En medio de largas discusiones familiares por la absoluta desconfianza de algunos de ellos a dicho programa, al país y a esa familia (puesto que solo la conocía por medio de internet), decidí salir de mi país, esta vez sin el apoyo económico de mi mamá, con su miedo total, pero aun así con su respaldo. Conté con el apoyo de algunas personas que veían este viaje como una oportunidad y no como un riesgo.

Lo que me motivó a enfrentarme con rebeldía a ese escándalo familiar era la curiosidad por conocer Europa, ver la nieve, mejorar mi escaso inglés, conocer otras culturas y viajar. En palabras de Gloria Anzaldúa, lo que me motivó fueron 'esos movimientos de rebeldía que tenemos en la sangre nosotras las mexicanas ${ }^{17}$ que surgen como ríos desbocanados en mis venas. Y como mi raza que cada cuando deja caer esa esclavitud de obedecer, de callarse y aceptar, en mí está la rebeldía encimita de mi carne” ${ }^{\text {18 }}$.

\footnotetext{
${ }^{15}$ Definiría el término cultura considerando la propuesta de Susie Jolly, en la cual menciona que la cultura debe ser entendida como: Diversa y dinámica, formada por influencias internas y externas y, estructurada bajo representaciones de poder o normas que impactan de manera diferente a las personas; por lo tanto, es un producto histórico y político en transformación continua, que puede ser percibido de manera distinta por las personas que habitan un mismo país o una misma comunidad.

Susie Jolly, Gender and Cultural Change. Overview Report (Bridge: Institute of Development Studies, 2002), $5-6$.

${ }^{16}$ Au pair se denomina a la persona acogida temporalmente por una familia a cambio de un trabajo auxiliar, normalmente como niñera; suele convivir con la familia receptora como un miembro más, recibiendo una pequeña remuneración económica. Diccionario de la lengua española, s.v. "Au pair", consultado el 01 de julio de 2015, http://lema.rae.es/drae/?val=Aupair/ https://es.wikipedia.org/wiki/Au_pair.

${ }^{17}$ [énfasis mío] en el cual modifico del texto original 'nosotros los mexicanos'.

18 Gloria Anzaldúa, "Movimientos de rebeldía y las culturas que traicionan" en Otras Inapropiables: Feminismos desde las fronteras, Coords. bell hooks, et. al. (Madrid: Traficantes de sueños, 2004), 71.
} 


\subsection{Segundo viaje. Croacia/Suiza}

Esta experiencia duró un año, en el cual viví todas las emociones en su máximo esplendor, tanto la alegría y el asombro como la tristeza y la soledad, entre muchas más. Me arrepentí docenas de veces por haberme alejado tanto de mi familia, amistades, de México, pero también me sentí orgullosa de mi decisión, de mi fortaleza y capacidad de adaptación. Estando allá me enteré de muchos fraudes que se realizaban por medio del programa Au pair y fue cuando me di cuenta de lo arriesgada que había sido, pero sin arrepentirme. Extraigo palabras de Judith Butler que hacen eco en relación a esto, de la conferencia "Vulnerabilidad y resistencia revisitadas en México" enunciada en la Universidad Autónoma de México en 2015, 'Somos vulnerables y después superamos esa vulnerabilidad a través de actos de resistencia; pero no hay que ser resistentes a la vulnerabilidad, sino a los regímenes que vulnerabilizan la vulnerabilidad, pues no podemos seguir pensando que la vulnerabilidad nos hace víctimas, hay que pensar que es nuestra vía a la resistencia'.

Conocí a muchas personas tanto de Croacia como de América Latina, que habían optado por vivir en Zagreb por múltiples razones. Durante una corta temporada, en aquel entonces (2008), la ciudad atravesaba por la xenofobia de un pequeño grupo de jóvenes pronunciada principalmente en contra de personas de piel obscura o que no hablaran el croata. Una tarde de invierno miembros de ese grupo pasaron caminando desafiantes, con logotipos neonazis y uniforme negro, frente a la cafetería en la cual me encontraba; sentí por primera vez en mi vida, miedo por mi color de piel, que en ese espacio adquiría la cualidad de "muy moreno”, recuerdo sentirme como invasora en un lugar que no me correspondía, no hablaba el idioma y había sido una decisión consciente el no aprenderlo, lo que me colocaba en situación de "presa-culpable”. Los consejos que algunos habitantes del lugar nos dieron a varias de mis amigas latinoamericanas y a mí, fueron no visitar algunos sitios en la periferia de la ciudad, no salir mucho y sobretodo no hablar, era cuestión de poco tiempo para que esos jóvenes se calmaran. Considero ahora estos "consejos" como una vía para perpetuar la violencia, era como pasar de la condición de víctimas a culpables. 
Puedo nombrarlo como el efecto del capitalismo heteropatriarcal racialmente estructurado, siguiendo el postulado de Bhavnani y Coulson $^{19}$ mediante el cual abordan un racismo de Estado que se plasma en diferencias de trato a distintos grupos de mujeres, aunque yo agregaría que también de otros grupos "fuera de la norma”, en el contexto de un capitalismo internacional, incorporando intersecciones como el nacionalismo y la inmigración.

Pero también noté el lado positivo de esa otredad, ya que mucha gente se acercaba a mí con curiosidad y amabilidad. México es un país famoso en ese territorio por su comida y telenovelas, así que me trataban muy bien con el deseo de aprender acerca de mi país, de mi idioma, compartiendo parte de su cultura y mostrándome a Croacia con hospitalidad.

Durante dicho tiempo, pase algunas temporadas en Ticino, la parte italiana de Suiza. Aquel lugar era fascinante para mí ya que sus paisajes me transmitían mucha paz, la cual se quebrantaba cuando mi carga laboral aumentaba, lo cual fue muy frecuente el último mes de mi estancia.

En ese lugar hice algunas amistades con adultos mayores, señores que paseaban con sus nietas/os, con quienes mantuve largas discusiones acerca de estereotipos, por ejemplo, el que las latinas que llegaban a Suiza lo hacían solo para “cazar maridos” o para ejercer la prostitución. Por su parte, trataban de convencerme de la pobreza de algunos de ellos, debilitando mi idea de que toda la gente en ese pequeño país contaba con unas condiciones de vida sumamente cómodas; me sorprendía también el hecho de que fueran más hombres en esa localidad los que salían a pasear más con las y los pequeños. Constantemente tratábamos de borrar etiquetas impuestas invisiblemente, que reducían en mucho las riquezas culturales.

No acepté la propuesta de quedarme un año más trabajando con esa familia, hecho que molestó bastante a Susana, lo cual manifestó pidiéndome continuamente el "favor" de quedarme más tiempo con Valeria (la pequeña a quien cuidaba) y apoyar con la limpieza del hogar. Así lo asumí al inicio, como "favores”, pero éstos se repetían con tanta frecuencia que

\footnotetext{
${ }^{19}$ Bhavnani y Coulson, "Transformar el feminismo socialista. El reto del racismo," en Otras Inapropiables, 51-62.
} 
me llevaron a percibir la diferencia en el trato que me daban Susana y Francesco, la primera me transmitió al final de mi estancia que yo era simplemente una empleada, para Francesco había sido parte de su familia.

La idea del apoyo incondicional por ser parte de la misma "raza" se destruyó, a pesar de que Susana continuamente hacía referencia a la importancia de ser paisanas, trayendo a colación frecuentemente que Chiapas había formado parte de Guatemala.

Mi primera experiencia viviendo en el extranjero fue sin duda algo que disfruté mucho, algo que hizo replantearme muchas cosas, entre ellas el fenómeno migratorio a nivel internacional, porque noté que como yo, habían muchas personas de tantas nacionalidades esparcidas por el globo terráqueo por diversas circunstancias y, por primera vez compartí lo escrito por Gloria Anzaldúa 'Cuando dejé mi casa no perdí el contacto con mis orígenes, porque lo mexicano forma parte de mí. Soy una tortuga, allá donde voy llevo mi «hogar» en mi espalda ${ }^{20}$.

\footnotetext{
${ }^{20}$ Anzaldúa, "Movimientos de rebeldía y las culturas que traicionan,” 78.
} 


\subsection{Tercer viaje. Múltiples destinos}

A mi regreso a México decidí volver a San Cristóbal, colaboré en varios proyectos relacionados con la psicología social para los cuales viajé dentro y fuera de Chiapas y México, aunado a ello, mi relación de pareja con un joven que habitaba en Alemania me mantenía en constante movilidad.

Uno de esos viajes fue a la India (finales de 2009- principios de 2010) donde el acercamiento al sistema de castas me conmocionó mucho, a pesar de que la marcada diferencia de clases sociales no era ajena a mi contexto. En una visita a un museo de textiles, vi una breve descripción de Vandana Shiva ${ }^{21}$, que llamó mucho mi atención por ser nombrada "ecofeminista", al leer brevemente algunas de sus campañas activistas relacionadas al fomento de saberes indios con la fuerte participación de las mujeres en la agricultura, me quedé intrigada, notaba una fuerte relación con mi entorno chiapaneco ya que en varias conversaciones con mi mamá, me compartía sus observaciones acerca de las prácticas de mujeres indígenas, las cuales coincidían con los escritos de Shiva. El resto del viaje las mujeres se convirtieron en mi foco de atención y el feminismo en ese zumbido en los oídos que te acompaña.

Posteriormente tuve un encuentro con feministas, Tatiana, Paola y Elsa, mediante un proyecto enfocado al fortalecimiento de capacidades para la implementación de la legislación nacional sobre la igualdad de género en Chiapas, lo cual ha representado un cambio muy importante en mi vida a nivel personal y profesional, ya que le dio nombre a muchas de las ideas, interrogantes, acciones emprendidas o deseadas en proyectos y vivencias previas; comencé a estudiar acerca de género, a leer a feministas, a colaborar en consultorías relacionadas al tema y gracias a todo esto, comencé mi camino hacia los Feminismos.

Conocí también a personas que trabajan el tema de la migración y trata de personas en Chiapas, aunado a ello, el bombardeo por los medios de comunicación acerca del tema, la aparición de películas y documentales que hablaban sobre las problemáticas que viven las y

\footnotetext{
${ }^{21}$ Shiva, es una filósofa hindú, activista y feminista, considerada como una de las principales exponentes del Ecofeminismo. Para mayores referencias, consultar: Vandana Shiva, Abrazar la vida, mujer, ecología y desarrollo (Madrid: Horas, 1995).
} 
los migrantes en su trayecto por México y mi encuentro con dos mujeres hondureñas que estaban de paso en San Cristóbal, orientaron mi interés hacia esta situación. Sin embargo, este tema lo percibía como algo infinito, desbordante. Por un lado me atraía mucho, por otro, me parecía que para tratarlo se necesitaba mucha preparación académica, psicológica y emocional que toma tiempo adquirir; pero son elementos necesarios en el abordaje de cualquier tema. 


\subsection{Cuarto viaje. Bologna/ Granada}

Después de una agotadora y constante búsqueda, surgió la posibilidad de situarme una vez más en el espacio europeo, esta vez como estudiante con el privilegio de estar becada, siendo así como entré de lleno a los estudios de género por medio del máster GEMMA ${ }^{22}$.

En mi estancia en Bolonia pude conocer algo de la migración en el contexto italiano, por los medios de comunicación, conferencias y clases que bajo la crítica literaria feminista ampliaron mi visión. A su vez, el abordaje de los feminismos desde esa perspectiva literaria ha influido en la manera de presentar este trabajo.

Por otro lado, en Granada me he acercado al activismo social relacionado a los movimientos

migratorios de personas de origen africano que intentan cruzar la "Fortaleza Europa" ${ }^{23}$. Tuve la oportunidad de viajar a Marruecos y observar a algunas personas en su intento por alcanzar "el sueño europeo" ${ }^{24}$, esto aunado a las clases tomadas durante el curso de movilidad en Granada, me han llevado a considerar las aportaciones de Carmen Gregorio como la base de mi preparación académica en el abordaje del tema migratorio bajo la perspectiva de género y la etnográfica feminista.

Tomando en cuenta estas experiencias, mi deseo por mostrar parte de la diversidad en la migración frente a los discursos homogeneizadores y mi interés por mostrar la agencia, entendida como la capacidad de acción y decisión de las personas que deciden moverse de lugar, es como he llegado a definir este tema de investigación.

\footnotetext{
${ }^{22}$ GEMMA son las siglas del título del máster en inglés: Erasmus Mundus Master’s Degree in Gender Studies.

${ }^{23}$ Retomo en este texto la categoría de Fortaleza Europa, dicho en palabras de Carmen Gregorio 'para evidenciar a modo de denuncia el régimen de fronteras erigido frente a la ciudadanía no europea en contraste con la libre circulación de bienes, capitales y ciudadanía nacional de países comunitarios'. Carmen Gregorio Gil, "La categoría género a la luz del parentesco en el análisis de las migraciones transnacionales," Anuario americanista europeo, no. 11 (2013): 11-29.

${ }^{24}$ Nombro "sueño europeo", al intento por llegar a tierras europeas, en este caso España, mediante la reutilización de la frase "sueño americano", la cual posteriormente ocuparé como "sueño mexicano", para definir al intento de personas centroamericanas por permanecer en territorio mexicano.
} 


\subsection{Invitación a un nuevo viaje por medio de los feminismos.}

“Hacia el sueño americano el viaje solo tiene una dirección, el norte...es largo y peligroso” (Somos

Migrantes)

Hay múltiples maneras de abordar el tema de la transmigración centroamericana ${ }^{25}$, vasta información y un gran arcoíris de herramientas teóricas y metodológicas que dan matices diversos al estudio de tal fenómeno. Por lo que no ha sido fácil ir definiendo las categorías, líneas teóricas y argumentos a ocupar en esta tesis. Sin embargo, ya que este máster es interdisciplinar y por mi intención de contribuir al dar a conocer y abordar este fenómeno desde una óptica feminista, tomaré como base la categoría de género, entendida como una categoría de diferenciación social, una construcción cultural, dinámica y contextualizada que acompañada de la interseccionalidad, comprendida a su vez como el medio para entender diversas formas de opresión simultáneas, que involucran a la raza, clase social, sexualidad, funcionalidad, entre otras, pueden generar subordinaciones, discriminaciones, invisibilizaciones que estructuran espacios y relaciones de poder. Esto bajo la guía de aportaciones feministas que desde diversas maneras de focalizar dichas relaciones, dan alternativas de respuesta, resistencia y transformación.

Muchas veces he escuchado decir 'lo importante no es el fin sino el trayecto' por ello el visibilizar lo que se vive atravesando fronteras, se convierte en una acción importante y en este caso hacerlo por medio de la academia, también en una apuesta política; es por ello que mi planteamiento se centra en el trayecto de personas centroamericanas por territorio mexicano, específicamente en el inicio de su estancia en este último país, acercándome a los significados que las y los transmigrantes dan a sus prácticas sociales en este viaje, para ver cómo opera la diferenciación de género en ese recorrido, como se va creando y/o transformando; esto mediante el abordaje de sus motivaciones, riesgos percibidos y estrategias contempladas en un viaje considerado uno de los más peligrosos del mundo.

\footnotetext{
${ }^{25}$ La transmigración en este trabajo es entendida como el fenómeno que indica el movimiento individual y/o colectivo de la población centroamericana que en su ruta hacia Estados Unidos o a otros lugares de la república mexicana tiene que pasar por territorio mexicano, haciéndolo en muchos casos de manera indocumentada.
} 
Parto de la idea de que moverse de sitio no debería ser considerado delito, la migración es un fenómeno que se ha dado desde el inicio de la vida, gracias a ella las sociedades se construyen y se enriquecen continuamente. Si bien, es importante contar con instancias que organicen este movimiento social y fluido, la manera de hacerlo debería atender las demandas y necesidades tanto de la población en tránsito como de quienes habitan los lugares transitados, para que esta movilidad no sea contemplada y vivenciada como problema y no perpetúe discriminaciones. Este argumento es muy complejo, sin embargo, una de las aportaciones que espero de este trabajo va en línea con la aproximación a algunas de estas demandas, por medio de voces transmigrantes que participan en este viaje.

El acercamiento a las subjetividades de las personas en tránsito da cuenta de las percepciones e interpretaciones que hacen de lo que las rodea, de las motivaciones que las llevan a emprender este viaje, a sabiendas de los posibles riesgos que se pueden presentar. Dichas motivaciones serán analizadas tomando en cuenta la óptica transnacional desde el enfoque de Diana Palmerín ${ }^{26}$ quien presta especial atención a los aspectos subjetivos vinculados con experiencias migratorias, ya que revelan los imaginarios que se tienen tanto del recorrido como de la meta.

En este trabajo además estas percepciones, interpretaciones y emociones, serán abordadas desde lo compartido con las personas transmigrantes y desde mi posición como investigadora y como mujer en movilidad, siguiendo las líneas de investigación aprendidas de Carmen Gregorio y Ana Alcázar, así como de las compañeras GEMMA. Retomando mi propia apreciación de la psicología, que va en contracorriente con la visión de la total objetividad de quien practique dicha ciencia, considerando la relevancia de las subjetividades contextualizadas en el entendimiento de los fenómenos sociales, en la interpretación del mundo y de quien lo habita, por lo tanto la subjetividad de quien investiga no puede quedar excluida.

\footnotetext{
${ }^{26}$ Diana Palmerín Velasco, "Entre el aquí y el allá: subjetividades transnacionales de género en el circuito migratorio Axochiapan-Minneapolis” (tesis doctoral, FLACSO México, 2011). http://repositorio.flacsoandes.edu.ec/bitstream/10469/3338/1/TFLACSO-2011DGPV.pdf.
} 
Por sí misma la transmigración centroamericana no había sido tan visibilizada pública y políticamente como un problema para México, ésta comenzó a cobrar esa dimensión cuando Estados Unidos modificó su política migratoria hacia la nación mexicana y Centroamérica, solicitando mayor control en la frontera sur, convirtiéndose en un espacio de privilegios y opresión en su máxima expresión.

El moverse de lugar y adentrarse a dicha frontera representa muchos retos, riesgos y aprendizajes, conocidos o desconocidos pero que pueden darse a conocer; citando a Nancy Tuana quien a su vez hace referencia a Donna Haraway, 'necesitamos tener la habilidad parcial de traducir las prácticas que mantienen la ignorancia entre comunidades muy diferentes y diferenciadas a través del poder. La ignorancia, al igual que el conocimiento, hay que situarla ${ }^{97}$, agregando que no es pasiva sino que es el resultado de muchos actos y muchas negligencias.

La decisión de qué conocimientos son válidos, quienes deben tener acceso a ellos, que experiencias deben mostrarse o no para la producción o evitación de las mismas, está intrínsecamente vinculada con las relaciones de privilegios y opresiones, lo cual ha sido demostrado y tensionado por teóricas feministas, tales como Peggy McIntosh ${ }^{28}$ y Katherine $\mathrm{O}^{\prime}$ Donnell $^{29}$ quienes definen al privilegio como una ventaja inmerecida que puede conceder dominación, en cambio la opresión es una exclusión sistemática de personas que no pueden participar como las demás en la sociedad. Son conceptos dinámicos, que van de la mano, no tienen carácter individual y, así como podemos beneficiarnos de ciertos privilegios también podemos experimentar ciertas opresiones. Es bajo estas premisas que ambos términos serán utilizados en este trabajo.

\footnotetext{
${ }^{27}$ Citando el texto original 'To this I would add that we need the ability partially to translate practices of ignorance among very different- and power-differentiated- communities. Ignorance, like knowledge, is situated'. Nancy Tuana, “The Speculum of Ignorance," Hypatia 21, no. 3(2006):3 [traducción mía].

${ }^{28}$ Peggy McIntosh, “Unpacking the knapsack of white privilege," Independent School 49, no. 2 (1990): 3136.

${ }^{29}$ Katherine O' Donnell, profesora invitada dentro del curso 2015 en Granada, de esa visita extraigo las ideas que acompañan a las de la autora anterior.
} 
Estos privilegios-opresiones van marcando la pauta para vivenciar vulnerabilidades y riesgos, entendidos como construcciones sociales desde la filosofía de Judith Butler y Zigmunt Bauman quienes con planteamientos diversos muestran cómo estos conceptos se entrelazan.

Bauman $^{30}$ por su parte hace énfasis en la importancia de la identidad, la cual es maleable y tiene que inventarse máscaras de sobrevivencia, puesto que permea la búsqueda de lo suficiente para sobrevivir y no lo suficiente para vivir, pero claro está, este principio no aplica para todas las personas; el proceso por el cual algunas de ellas tienen que enfrentar ciertos riesgos para integrarse a una sociedad cada vez más global, las puede llevar a ser simplemente percibidas como "residuos humanos" como consecuencia de la modernidad, de la fluidez de la sociedad, yo agregaría, del patriarcado. Las luchas reivindicativas, como el feminismo ha vislumbrado de manera vertiginosa esta situación.

Las aportaciones de Butler, sugieren que la vulnerabilidad es un tipo de receptividad y capacidad de respuesta que moviliza, lo cual implica que resistencia y vulnerabilidad operan juntas y no son contrarias, pues la vulnerabilidad no es lo contrario al poder de actuar. 'Si entendiéramos que somos vulnerables y permeables, podríamos pensar de modo distinto sobre la inmigración, y ver las fronteras no como barreras para mantener a los extranjeros al otro lado, sino como lugares de paso, modos de transacción y espacios en los que se produce la interpenetración cultural ${ }^{31}$.

Para enfrentar los posibles riesgos, las personas transmigrantes y algunas personas en favor de este encuentro desarrollan estrategias o destrezas para hacer este viaje mejor habitable. Cabe mencionar que el objetivo de abordarlas estaba relacionado en primera instancia con mostrar las estrategias que las mujeres transmigrantes desarrollan para hacer este viaje, con cierto resentimiento $^{32}$ quería romper de alguna manera con el estigma que he escuchado

\footnotetext{
${ }^{30}$ Zygmunt Bauman, Vidas desperdiciadas. La modernidad y sus parias (Buenos Aires: Ediciones Paidós, 2006).

31 Judith Butler, Violencia de Estado, guerra, resistencia. Trad. Patrícia Soley-Beltran (Madrid: Katz Editores, 2011), 62-63.

${ }^{32}$ Retomo la idea de Mari Luz Esteban quien después de leer un artículo de Juan José Millás reflexionó acerca de que 'probablemente el trabajo de investigación y, concretamente una buena autoetnografía pueda tener también en el resentimiento un buen punto de partida'.
} 
desde discursos políticos, diversos medios de comunicación o conversaciones con algunas personas, el estigma de la mujer centroamericana, pobre (no solo en el sentido económico) e ignorante, que no sabe a qué se enfrentará en un viaje como éste, vinculado al dominio masculino. Estando en terreno este objetivo se amplió.

Trataré a las e-mociones como estrategias propias, “contagiosas” y dinámicas, ya que pueden ser apropiadas, situadas, replicadas y productoras de poder, pero a su vez son producto del mismo. Tal como lo menciona Besserer 'Nos interesa definir a las emociones en relación con el movimiento de los sujetos. Por eso proponemos una ortografía que enfatice que se trata de movilización, en este sentido son e-mociones ${ }^{33}$.

Otra de las estrategias que contemplo está relacionada con la cultura material, desde la perspectiva arqueológica feminista, la cual encuentro muy útil para la deconstrucción de mitos y estereotipos. El análisis que Jason de León ${ }^{34}$ y Judith Boruchoff ${ }^{35}$ hacen con relación a los artefactos y sus usos, por parte de las y los transmigrantes en su trayecto hacia Estados Unidos me parece muy pertinente para este trabajo. Además el compartir lo aprendido en esta experiencia en relación a este tema se ha convertido en un compromiso personal, aunque lo personal es político y también teórico ${ }^{36}$.

\section{'Hay que darle armas al pueblo, puesto que el Estado está armado' Toni Negri.}

Atravesar fronteras en sus múltiples sentidos, enfrenta a otredades, el cómo hacerlo lleva a generar diversas estrategias para las cuales encuentro al decolonialismo como la teoría iluminadora para entender mejor estos argumentos. Sin duda, son muchas las autoras e ideas que me gustaría nombrar, sin embargo, he decidido acompanarme de Gloria Anzaldúa,

Mari Luz Esteban, “Antropología encarnada. Antropología desde una misma”, Papeles del CEIC. International Journal on Collective Identity Research, no.12 (junio, 2004): 9.

${ }^{33}$ Federico Besserer Alatorre, "Regímenes de sentimientos y la subversión del orden sentimental," Nueva Antropología XXVII, no. 81 (julio-diciembre 2014): 62.

${ }^{34}$ Jason de León, “Better to Be Hot than Caught,” American Anthropologist 114, no. 3 (2012): 477-495.

${ }^{35}$ Judith Boruchoff, "Equipaje cultural," Fronteras fragmentadas (1999): 499-518.

36 Carmen Gregorio Gil, "Traspasando las fronteras dentro-fuera: Reflexiones desde una etnografía feminista," AIBR, Revista de Antropología Iberoamericana 9, no. 3 (2014): 299, citando a Judith Okely, "The Self and Scientism" en Journal of the Anthropology Society of Oxford, (UK: University of Oxford, 1975). 
Chandra Mohanty, Gayatri Spivak y Yuderkys Espinosa Miñoso ${ }^{37}$, ya que sus legados relacionados a la otredad, subalternidad y agencia de las personas que van cruzando fronteras y creando puentes, hacen eco con algunos imaginarios y percepciones que llevo conmigo de las personas en movilidad, que en su búsqueda hacia una vida diferente se/nos enfrentamos a espacios y circunstancias diversas, a la noción de un "nosotras/os" frente a "otras/os" que parece una constante en esta fase del trayecto migratorio.

Esto demuestra, al menos así lo espero, las riquezas que las teorías feministas ofrecen para hacer frente a situaciones sociales, en este caso transmigratorias. En este documento interactúan simultáneamente en alianza con otras que, aunque no sean nombradas influyen en mis ideas y percepciones, fortaleciendo mi entendimiento de dicho fenómeno en el contexto sureño-centroamericano.

Desde mi apuesta por la parcialidad, te invito a acompañarme en este nuevo viaje, esta vez recorriendo algunas historias de vida entretejidas.

\footnotetext{
${ }^{37}$ Ya que son varias obras de dichas autoras las que han sido ocupadas, las señalaré cuando haga referencia directa a las mismas.
} 


\section{Capítulo 2. Planeación del viaje}

"Write with your eyes like painters, with your ears like musicians, with your feet like dancers. You are the truthsayer with quill and torch. Write with your tongues of fire..." (Gloria Anzaldúa) ${ }^{38}$

\subsection{Definición del destino}

Como mencioné previamente la frontera sur, entre México y Guatemala, era como un enigma para mí; la oportunidad de escribir una tesis con plena libertad en la elección del tema me ha permitido comenzar a adentrarme en él. Es por ello que en este capítulo describiré el proceso metodológico que decidí llevar a cabo para definir el destino y el cómo hacer este viaje.

Durante la carrera universitaria tuve un breve acercamiento a la antropología, pero fue más bien dentro de mi desarrollo profesional que conceptos tales como, trabajo de campo, in situ y etnografía comenzaron a tener sentido para mí. Al leer algunos de los trabajos de Carmen Gregorio me sentí identificada porque explicaba de manera muy clara mi visión de las mujeres migrantes y la importancia del trabajo de campo en las investigaciones; esto me llevo a acercarme tanto a la antropología como a la etnografía feminista.

Y a pesar de mi casi nula experiencia relacionada a tales ciencias, lo que tenía claro era que quería estar en el lugar donde pudiera hablar y convivir con las personas transmigrantes, acercarme tanto a sus prácticas como a los significados que le daban a las mismas, lo cual me llevaría a conocer la construcción de género en un contexto vinculado a la violencia y al ejercicio de poder en constante cambio.

Recupero aquí algunas de las ideas de Carmen Gregorio que desde mi punto de vista dan claridad a la pertinencia de ocupar las líneas mencionadas previamente.

'La antropología feminista al mostrar las múltiples formas de expresión de las diferencias de género en su imbricación con otras diferenciaciones: de parentesco, sexualidad, extranjería, etnicidad, ha contribuido a la deconstrucción del sujeto mujer como categoría homogénea y

\footnotetext{
38 "Escribe con tus ojos como si fueran pintores, con tus oídos como músicos, con tus pies como bailarines. Tú eres la oradora con pluma y antorcha. Escribe con tus lenguas de fuego...”.

Cherry Moraga y Gloria Anzaldúa, This bridge called my back: Writings by radical women of color (NY: Kitchen Table, Women of Color Press, 1983), 173 [traducción mía].
} 
esto en ocasiones se ve confrontado con la necesidad del feminismo de construir un sujeto político $^{39}$.

En ese mismo texto la autora apunta lo siguiente: 'Las perspectivas feministas, al interpretar el propio acto de categorizar como una expresión de poder, se inscriben en una nueva etnografía que propone la deconstrucción de categorías fijas e inmutables asignadas a los sujetos. Sus planteamientos deconstruyen la noción de identidad de género como entidad fija que actúa en el campo, para proponer la noción de persona que experimenta y se transforma, en las relaciones con los otros ${ }^{90}$.

Desde los postulados de Behar y Gordon" ${ }^{41}$, se espera a la nueva etnografía como un medio para reflejar una profunda autoconciencia del funcionamiento del poder y la parcialidad de toda la verdad, tanto en el texto como en el mundo. La nueva etnografía desde esta perspectiva feminista no resolverá los problemas profundamente preocupantes de desigualdad en un mundo impulsado por el capitalismo global, pero al menos es una herramienta para tratar de descolonizar las relaciones de poder inherentes a la representación de la Otredad.

Entiendo entonces a la investigación etnográfica feminista como un método que consiste en observar y tratar de conocer los significados que se les otorga a ciertas prácticas sociales desde las voces de quienes las practican, con la participación directa de quien investiga, es decir que toma en cuenta las subjetividades de ambas partes, tanto el cuerpo, la mente, las emociones y los espacios en las cuales fluctúan. Esto permite acercarse y entender en cierta medida un fenómeno social donde las relaciones de poder se suscitan de manera contextualizada. Este acercamiento requiere de un ejercicio de reflexividad constante con el apoyo de la mirada, la cual considero en palabras de Teresa del Valle como 'un conjunto de dispositivos, habilidades y recursos que ponemos en práctica para conocer a través de la

39 Carmen Gregorio Gil, "Contribuciones feministas a problemas epistemológicos de la disciplina antropológica," AIBR, Revista de Antropología Iberoamericana 1, no. 1 (2006): 39.

${ }^{40}$ Marilyn Strathern, "Fuera de contexto. Las ficciones persuasivas de la antropología," en El surgimiento de la antropología posmoderna. Coord. Carlos Reynoso (Barcelona: Gedisa, 1998), citada por Gregorio Gil, "Contribuciones feministas a problemas epistemológicos de la disciplina antropológica," 30.

${ }^{41}$ Ruth Behar y Deborah Gordon, Women Writing Culture (Berkely y London: University of California Press, 1995). 
experiencia y mediante una actitud de apertura, la diversidad de datos, interpretaciones, emociones, contradicciones, extrañezas e interrogantes como parte de lo que ofrece la inmersión en la situación elegidat' ${ }^{92}$.

Con base a estas ideas y a mi acercamiento previo al fenómeno migratorio en el contexto sureño mexicano, decidí realizar el trabajo de campo en la ciudad de Tapachula, la cual se encuentra en una zona fronteriza con Guatemala (Mapa 1). La mayor parte de la población en esta ciudad es mestiza, forjada en más de una centuria por las migraciones que tanto la riqueza natural de la zona como el negocio del café motivaron a personas de origen europeo y asiático a ocuparla. Es considerada la puerta de entrada a México, el adentrarse al país por medio de ésta representa un reto, sin embargo, el mayor desafío consiste en superar esta ciudad para continuar el viaje, por lo tanto es un espacio para el tránsito breve o prolongado de transmigrantes.

Debido a que la población con la cual me interesa trabajar está en constante movilidad, decidí instalarme en uno de los albergues que ofrecen apoyo a la población migrante en dicha ciudad, ya que podría ser un espacio donde vivenciar las prácticas sociales de forma más segura.

En este sentido, elegí la Red Scalabrini, puesto que son albergues que están presentes en puntos importantes del recorrido migratorio desde Guatemala hasta la frontera con Estados Unidos y que, fueron creados por los Misioneros de San Carlos- Scalabrinianos fungiendo como punto de acogida generalmente durante tres días. En Tapachula, así como en otras ciudades mexicanas, este albergue fue fundado por el sacerdote italiano Flor María Rigoni, quien tiene una vasta experiencia relacionada con el fenómeno migratorio en diversos países. Sus iniciativas sociales enfocadas a formular soluciones en favor de las personas en movilidad me parecen muy interesantes, es por ello que solicité realizar mi estancia de cinco semanas en el también llamado “Albergue Belén”.

Esta investigación fue multisituada, si bien el albergue "Belén" fue el espacio en el cual pase la mayor parte del tiempo, también me acerqué a esa realidad social visitando otros espacios,

42 Teresa del Valle, "Un ensayo metodológico sobre la mirada en la antropología social," Gazeta de Antropología 8, no.3 (2012): 2. 
además durante mi estancia se dio la oportunidad de hacer algunas de las retribuciones por la participación de la gente en este proyecto mediante actos que me llevaron a conocer otras instancias. Los lugares visitados fueron: El albergue "Buen Pastor" situado en Tapachula, el albergue Casa del Migrante "Sin Fronteras (Mi’n Npon B’aj)” ubicado en Tecún Umán, Guatemala. La Comisión Mexicana de Ayuda a Refugiados (COMAR), el Instituto Nacional de Migración (INM), los consulados de Honduras y Guatemala, agencias de Naciones Unidas tales como el Organismo Internacional de Migraciones (OIM) y el Alto Comisionado de las Naciones Unidas para los Refugiados (ACNUR), así como espacios en el centro de la ciudad, como comedores económicos, casetas telefónicas y el zócalo de la ciudad.

Como parte del proceso realicé entrevistas semi-estructuradas diferenciadas, a partir de guías diseñadas para tal fin (anexo I). Dichas entrevistas se diferenciaron de la siguiente manera: una para acercarme a las personas transmigrantes tomando en cuenta como temas a abordar las motivaciones para realizar el viaje, la percepción del país de destino y del país de tránsito, los riesgos que contemplan podrían aparecer durante el trayecto y las estrategias a ocupar para evitarlos o disminuirlos; la otra guía estaba dirigida al personal de las instancias que conviven frecuentemente con las personas transmigrantes para conocer su percepción acerca de las mismas. Aunque si bien, este instrumento de entrevista fue una buena orientación, la improvisación en este tipo de trabajo es ineludible y necesaria, por lo cual fue mi gran compañera. 


\subsection{Contextualizando el Viaje}

"No es el centro lo que determina la periferia, sino la periferia lo que, en su cualidad limitadora, determina el centro". (Chandra Mohanty) ${ }^{13}$

Planteo ahora, antes de adentrarnos de lleno en esas tramas de vida, dar cuenta del contexto en el cual se llevó a cabo este viaje.

\subsubsection{Breve acercamiento histórico a la transmigración centroamericana}

América Central también llamada Centroamérica, está rodeada por el océano Pacífico y el océano Atlántico. Políticamente se divide en siete países independientes: Guatemala, Belice, Costa Rica, El Salvador, Honduras, Nicaragua y Panamá (Mapa 2).

La situación sociopolítica y económica centroamericana desde la década de los años setenta se ha caracterizado por sufrir crisis relacionadas a conflictos armados, golpes de Estado y desastres causados por fenómenos naturales como el Huracán Mitch en 1998 y la Tormenta Stan en 2005. Hechos que han agudizado las condiciones de pobreza y desempleo principalmente en las zonas rurales, aunado a los ajustes estructurales que los diversos gobiernos han implementado mediante la aplicación de políticas neoliberales, dando entrada a empresas transnacionales y a tecnologías que han acabado con muchos de los pequeños negocios familiares o han reducido la mano de obra.

Además, está región se encuentra ubicada en la principal zona productora y consumidora de drogas en este continente, dando un fuerte despunte al narcotráfico, pandillerismo, contratación de sicarios, lavado de dinero, trata de personas, entre otros delitos. Convirtiéndose en un problema de seguridad y gobernabilidad, puesto que algunas/os servidores públicos participan en este entramado delictivo.

Hasta mediados del siglo veinte, los patrones migratorios imperantes eran rural-rural y ruralurbano, en función de un modelo agroexportador que requería mano de obra para la cosecha de cultivos como el café, algodón y caña de azúcar. En los años setenta y ochenta, la migración estuvo determinada además, por conflictos armados internos que afectaron a toda

\footnotetext{
${ }^{43}$ Chandra Mohanty, Bajo los ojos de occidente. Trad. María Vinós (Madrid: Cátedra, 2008), 19.
} 
la región, ya fuera como expulsores de desplazadas/os forzosos (Guatemala, El Salvador, Nicaragua) o como receptores de refugiadas/os (Honduras, Costa Rica, Sur de México).

La antropóloga Elana Zilberg ${ }^{41}$ menciona otros factores relacionados con el aumento de la migración internacional en las últimas dos décadas, los cuales tienen carácter cultural y están estrechamente relacionados con los avances tecnológicos, ya que la creciente difusión de modelos de consumo en otros lugares hacen atractiva y prometedora la búsqueda de nuevas oportunidades en esos espacios.

Otro elemento importante a considerar es la migración de personal calificado que no encuentra oportunidad para su realización profesional en estos países, lo que se denomina "Fuga de cerebros o Brain Drain".5.

Se fortalece la imagen de Estados Unidos como nación llena de oportunidades, convirtiéndose así en el "sueño americano", esto en gran medida para población de Guatemala, El Salvador, Belice, Honduras y México. Para el caso de Nicaragua y Panamá, debido a la cercanía, a la oportunidad de acceder con mayor facilidad y por la solvencia económica de Costa Rica, en muchos casos optan por ir a este último destino.

La diversidad de la migración centroamericana que cruza el territorio mexicano podría sintetizarse en los siguientes flujos ${ }^{46}$ : a) Visitantes locales (con residencia fronteriza); b) Trabajadores agrícolas temporales (principalmente para personas guatemaltecas); c) Refugiadas/os de Guatemala; d) Residentes fronterizos; y, e) Transmigrantes (documentadas/os e indocumentadas/os).

México ocupa un lugar importante en ese trayecto migratorio. Cada año, miles de personas atraviesan este país sin permiso legal, ya que obtener visas para cruzar la nación es un trámite

\footnotetext{
44 Elana Zilberg, "La relocalización de la cultura en la migración internacional," en Migración Internacional y Desarollo, Editado por Mario Lungo (San Salvador: FUNDE, 1995), citada por Ana Silvia Monzón, "Las viajeras invisibles," PCS-CAMEX, (2006): 9.

45 Diccionario de la lengua española, s.v. "fuga de cerebros", consultado el 6 de abril de 2015, http://lema.rae.es/drae/?val=fuga+de+cerebros.

${ }^{46}$ Monzón, Las viajeras invisibles, 42.
} 
largo y costoso. El viaje es considerado como uno de los más peligrosos del mundo debido a la presencia del crimen organizado, animales y corrupción en este trayecto.

'México es un enorme filtro vertical, un gigantesco embudo que va frenando el avance de migrantes, diezmando su volumen, seleccionando a los más resistentes y perseverantes, a quienes más recursos tienen. Pero es un embudo que sólo consigue aumentar la presión sin disminuir significativamente el flujo, ${ }^{9}{ }^{47}$

A partir de los atentados terroristas sufridos en Estados Unidos en el 2001 y debido al incremento de personas indocumentadas en este país, se reforzaron los controles migratorios. Aunado a ello en el 2014 el gobierno federal mexicano impulsó el Programa Integral Frontera Sur, gracias a una subvención de Estados Unidos que, tras una grave crisis migratoria que llevó a dar cuenta de las numerosas personas centroamericanas menores de edad que cruzan las fronteras sin compañía de adultas/os; es por ello que los controles migratorios se han multiplicado vertiginosamente. Según el comunicado oficial ${ }^{18}$, este programa plantea brindar mayor protección y seguridad a las personas migrantes en su paso por México, velando por sus derechos humanos y fomentando la convivencia armónica, sobretodo en su recorrido por las vías férreas, controlando el tren "La Bestia" ". Sin embargo, la percepción de algunas investigadoras, algunas personas transmigrantes y la mía, es que Estados Unidos se ha involucrado más activamente por medio de este programa ya que el interrumpir el trayecto migratorio desde la frontera sur representa una gran reducción de costos y tiempo en las deportaciones para dicho país.

\footnotetext{
${ }^{47}$ Artza Larraitz Lexartza, Ana Carcedo Cabañas y María J. Chaves Groh, "Mujeres centroamericanas en las migraciones," PCS, CEFEMINA (2012):54.

48 Para mayor información consultar: DOF 08/07/2014. Consultado por última vez: 04/07/2015. http://observatoriocolef.org/admin/documentos/DRECRETO\%20FROTERA\%20SUR.pdf.

${ }^{49}$ Es también conocido como "tren de la muerte", Flor María lo nombra "tren de la Esperanza", el cual es una red de trenes de carga de mercancías que son utilizados por transmigrantes como vehículo hacia Estados Unidos o bien para llegar a alguna ciudad mexicana cerca de las vías ferroviarias. Este modo de viajar es ilegal y peligroso.
} 
Este fenómeno migratorio, retomando las aportaciones de Saskia Sassen ${ }^{50}$, llega a ser benéfico para los Estados centroamericanos de mayor expulsión migratoria, puesto que la salida de contingentes de la población más excluida o insatisfecha, disminuye la denuncia sobre la actuación estatal, en demanda de servicios públicos y en la defensa de los derechos humanos. Además la entrada y manejo de las remesas representa un beneficio para los Estados, tanto del país emisor como del receptor.

${ }^{50}$ Saskia Sassen, Contrageografías de la globalización Género y ciudadanía en los circuitos transfronterizos (Madrid: Traficantes de sueños, 2003). 


\subsubsection{Feminización de las Migraciones}

"Son numerosas las huellas de estas viajeras silenciosas que están resignificando derechos, vinculando personas y culturas, superando incertidumbres, legando saberes” (Ana Monzón)

A pesar de la alta presencia femenina que ha llegado a ser mayoritaria en particular en América Latina, el fenómeno migratorio ha sido visto y analizado en clave masculina, lo que explica, la escasa información (no solo estadística), que se ha desarrollado sobre las mujeres vinculadas a la migración pero gracias al feminismo esto está cambiando.

Se habla de feminización no solo por este aumento de la presencia de mujeres en los contingentes de migrantes, también porque se empieza a notar que las mujeres están migrando en primera persona y por decisión propia, no solo como acompañantes de hombres que migran o para reunirse con ellos.

Como señala Rojas ${ }^{51}$, en México como en otros países, esta participación femenina en la migración no había sido objeto de estudio puesto que los enfoques teóricos prevalecientes hasta la década de 1960 y 1970 no permitían desentrañar diferencias en esta participación. Fue necesaria la influencia de todo un desarrollo en las ciencias sociales, incluyendo la estadística social, para empezar a reconocer tales diferencias, deconstruir categorías, desagregar datos y descubrir las múltiples relaciones que se establecen o pueden establecer entre variables.

El fuerte impulso que se ha dado en la feminización de las migraciones en esta región geográfica (como en otras), parte también de la lógica de la globalización del mercado laboral, puesto que el incremento en la demanda de mano de obra femenina "poco calificada" se concreta en los servicios de cuidados vitales, dando pie a la "cadena global de

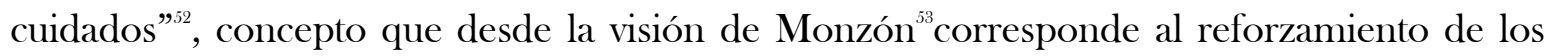
roles inequitativos de género y a la continuidad en la separación entre las esferas pública y

\footnotetext{
${ }^{51}$ Martha Luz Rojas Wiesner, "Mujeres y migración en la frontera sur de México," Amérique Latine Histoire et Mémoire. Les Cahiers ALHIM 14 (agosto, 2008), consultado 8 de febrero de 2015. https://alhim.revues.org/2252?lang=fr

52 Arlie Hochschild, “The nanny chain,” American Prospect 11, (January 2000): 32-36.

${ }^{53}$ Monzón, Las viajeras invisibles, 9.
} 
privada en detrimento de las mujeres, afectando tanto a las inmigrantes en los lugares de llegada, como a las mujeres que se quedan en el lugar de origen, ya que muchas ocasiones las primeras dejan a sus hijas/os al cuidado de otras mujeres, creando redes de cuidados desde diferentes posiciones. Ahora bien, contribuyen a su vez a la construcción de nuevas identidades y relaciones, que van fusionando elementos culturales de los diversos países.

Las condiciones de trabajo de estas mujeres, ocupadas en su mayoría en actividades productivas precarias e inseguras, sin duda deben ser parte central de las consideraciones en las políticas públicas. A su vez, 'el reconocer la violencia contra las mujeres, entre las causas de la migración forzada femenina es fundamental para orientar políticas públicas e iniciativas para la defensa de los derechos de éstas tanto en los países de origen como en los de destino ${ }^{54}$ y yo agregaría también a los países de tránsito.

En muchos casos, la migración constituye una estrategia para mejorar su situación económica, para encontrar una forma de vida más agradable y enriquecedora. Aunque también se registran casos de mujeres migrantes que intentan cruzar el territorio mexicano para buscar refugio y apoyo ante situaciones de conflictos políticos, religiosos, discriminatorios, entre otros.

Las desapariciones de personas migrantes en territorio mexicano es una realidad que está siendo más visible por la falta de respuesta. Las mujeres están actuando de manera muy amplia en demanda de dichas respuestas. 'No está de más señalar que las mujeres hasta el momento son, además, quienes constituyen el grueso de quienes buscan a sus familiares migrantes que desparecen en territorio mexicano, así como la mayoría de quienes defienden en Mesoamérica los derechos de las personas migrantes. Se trata de otras formas de vinculación de las mujeres con las migraciones que usualmente pasa desapercibida ${ }^{95}$.

Otro de los argumentos que forman parte del debate en relación a la migración de mujeres, está vinculado con el trabajo sexual y la trata de personas; si bien, son actividades que están presentes en el fenómeno migratorio, no son generalizables, no todas las mujeres al migrar tienen que desarrollar el trabajo sexual, ni todas son o pueden ser víctimas de trata, esta

\footnotetext{
${ }^{54}$ Lexartza, Carcedo y Chaves, "Mujeres centroamericanas en las migraciones”, 30.

${ }^{55}$ Ibid, 8.
} 
problemática va más allá de estas consideraciones reducidas. Autoras como Dolores Juliano $^{56}$, Carmen Gregorio ${ }^{57}$, entre otras, ya han abierto el tema en este sentido, a partir de la introducción de la perspectiva de género en los estudios sobre inmigración, donde se ponen en evidencia numerosos estereotipos sobre la imagen de las mujeres migrantes, por lo cual dichas autoras han tratado de superar esas consideraciones limitadas.

Reconocer la migración desde la perspectiva y el lugar que ocupan las mujeres nos obliga a incorporar nuevos elementos al análisis del fenómeno, teniendo muy en cuenta que tanto el lugar de origen, la ruta migratoria y el lugar de destino están marcados por construcciones de género, así como la manera de experimentar tanto la decisión de viajar como el viaje mismo.

\footnotetext{
56 Dolores Juliano, "Mujeres estructuralmente viajeras: Estereotipos y estrategias," Papers, revista de sociología 60, (2000): 381-389.

${ }^{57}$ Gregorio Gil, “Mujeres inmigrantes,” 42-54.
} 


\subsubsection{Albergues}

"Hay tantísimas fronteras que dividen a la gente, pero por cada frontera existe también un puente" (Gina Valdés) $^{58}$

En este trayecto migratorio hay múltiples riesgos que se pueden vivenciar así como también múltiples y diversificados apoyos que pueden recibir las personas transmigrantes. En el marco de las redes de apoyo, los procesos de intervención comunitaria, grupal o individual, de organizaciones sociales, no gubernamentales y centros de investigación tienen una alta presencia, colaborando de variadas formas en pos de la solidaridad sin fronteras. Los albergues son una muestra de ello y dado que ocuparon un lugar especial en este trabajo, haré una descripción de los mismos para situar a mis lectoras/es en el espacio habitado.

Estos albergues han sido constituidos para la recepción, atención y apoyo para transmigrantes, en donde además de la posibilidad de encontrar un techo temporal, comida, regaderas, atención médica, ropa, zapatos, medicina, diversos insumos e información, encuentran un espacio donde se dignifica su experiencia migratoria.

Los servicios proporcionados varían de acuerdo al albergue, los cuales se cubren bajo apoyos diversos provenientes de la iglesia católica, instancias sociales o donativos de la población en general, pero en ningún caso con financiamiento gubernamental.

${ }^{58}$ Claira Joysmith, "Ya se me quitó la vergüenza y la cobardía," En Fronteras y cruces: Cartografía de escenarios culturales latinoamericanos, Coords. Maria Belausteguigoitia y Martha Leñero (México: UNAM, 2006), 215. 


\section{a) Albergue "El Buen Pastor"}

Este albergue fue fundado en Tapachula por Olga Sánchez Martínez (Fotografía 1), después de vivenciar el encuentro continuo con personas migrantes que habían sufrido algún tipo de accidente en "La Bestia”.

Es por ello que la función principal del albergue además de ofrecer alojamiento y alimentación, es atender a las personas que por experimentar alguna caída o evento desafortunado en la ruta ferroviaria no pueden continuar el viaje, requiriendo apoyo médico desde curaciones sencillas hasta prótesis (Fotografía 2). A su vez, brindan alojamiento a mexicanas/os que vienen a esta ciudad a recibir quimioterapias y no cuentan con un refugio o familiares que puedan apoyarles (Fotografía 3).

Cuenta con una panadería, siendo la principal vía para la obtención de recursos económicos.
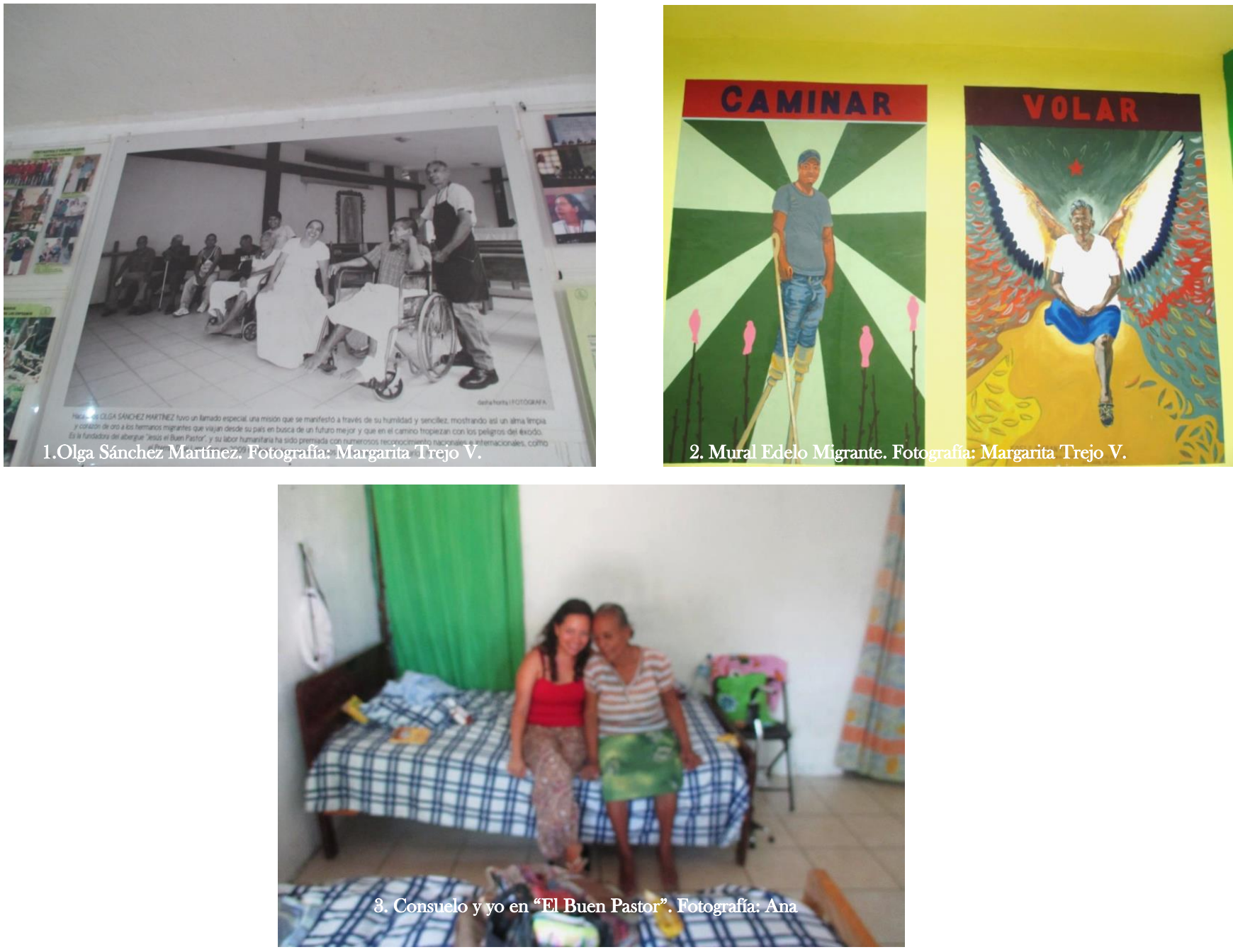


\section{b) Casa del Migrante “Sin Fronteras (Mi’n Npon B’aj)”. Tecún Umán}

Este albergue se encuentra en el paso fronterizo del río Suchiate entre México y Guatemala. Es parte de la red Scalabrini, fue fundado en 1996 y cuenta con una oficina de derechos humanos abarcando tres áreas: Trabajo social, donde mediante entrevistas detectan violaciones a los derechos humanos y/o la necesidad de recibir atención médica para lo cual se transfieren a otras instituciones. El área de asesoría jurídica, se encarga de informar del proceso legal en caso de ser detenidas/os o deportadas/os facilitando contactos de apoyo en México y Centroamérica para evitar o denunciar violaciones a los derechos humanos y, en la medida de lo posible, apoya en la búsqueda de familiares de migrantes desaparecidas/os. Por último, el área de educación, proporciona asesoría psicológica y espiritual, llevando a cabo eventos culturales para la sensibilización a la población sobre el fenómeno migratorio (Fotografía 4).

Decidí visitar este lugar, puesto que mucha gente lo mencionaba como referente importante antes de iniciar su trayecto migratorio en México.

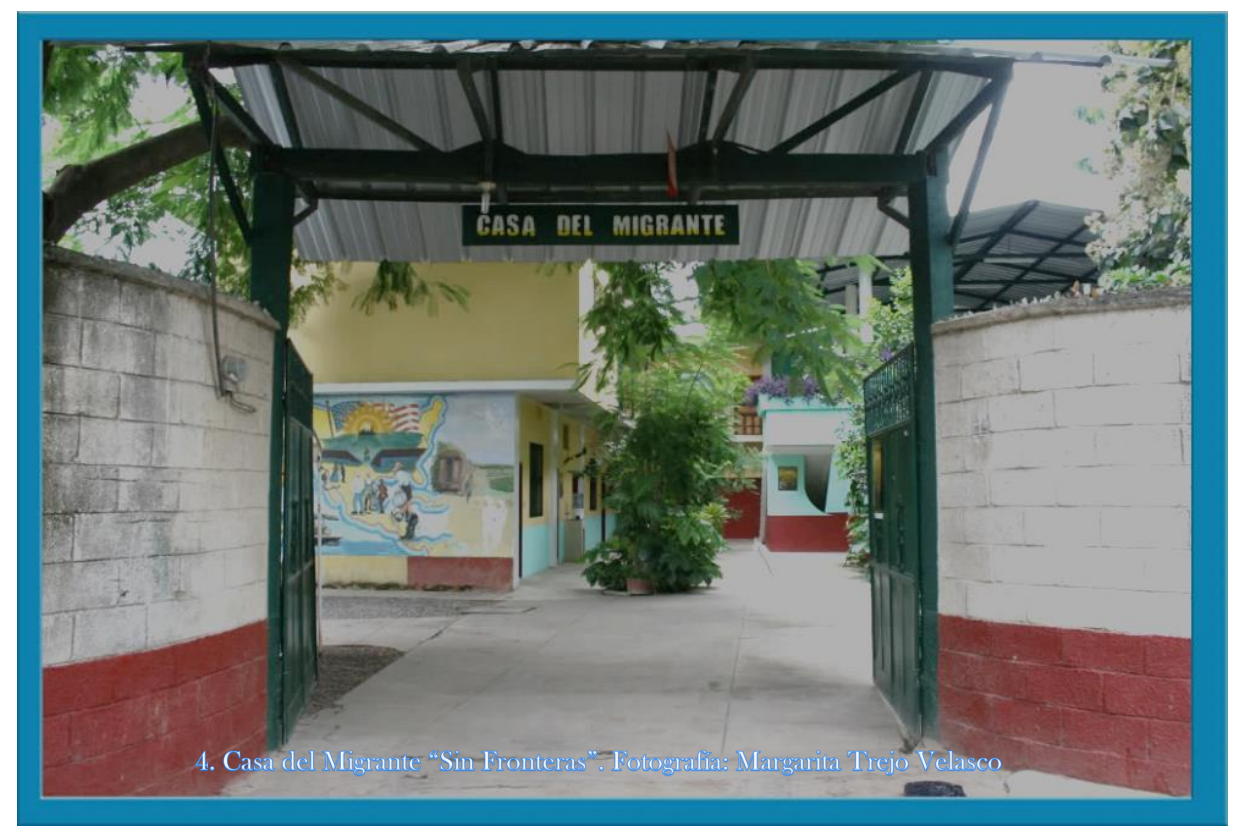




\section{c) Albergue "Belén"}

También parte de la red Scalabrini, fundado en 1997. Tiene un cupo de 45 personas y además de alojamiento, se trabaja por la defensa y promoción de los derechos humanos.

El dar cuenta de este albergue es importante, puesto que de acuerdo con Paula Soto ${ }^{59}$ al hablar de espacio, tenemos una referencia identitaria que permite a las personas construir relaciones sociales y a través de la multiplicidad de éstas, conformar la trama social donde se juega su ubicación y movilidad en el mapa social imaginario (Fotografías 5,6).
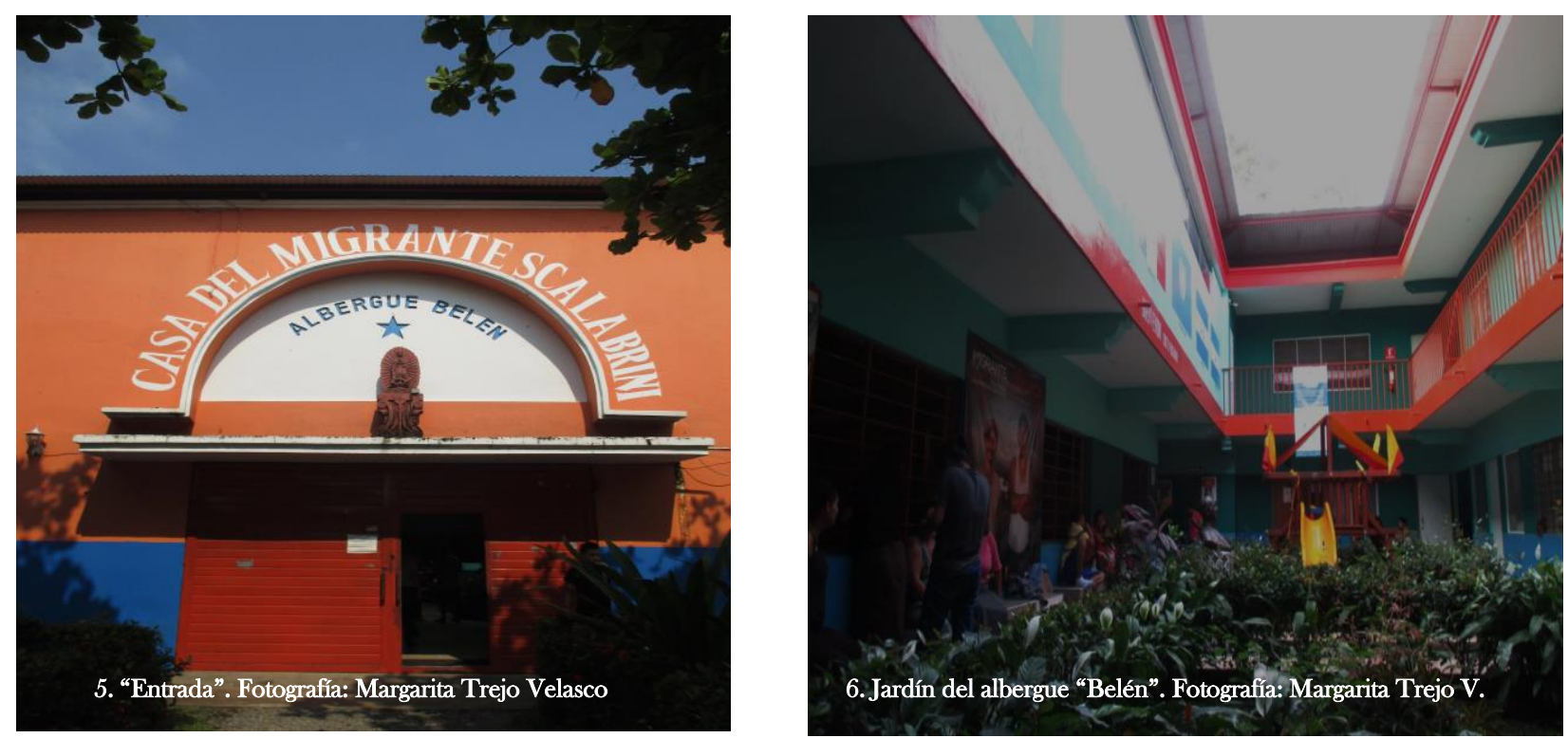

Este albergue está ubicado en una casa grande, cuenta con cámaras de seguridad al interior y al exterior, las cuales son monitoreadas constantemente. Frente a la puerta principal se encuentra la oficina de registro y enfrente de dicha oficina la que fue mi habitación.

Justo en la entrada hay una pizarra con fotografías de enganchadores (Fotografía 7) y números de denuncia en caso de encontrarlos. Se encuentran también la bodega donde se almacenan los donativos, el consultorio médico y el dental, frente a los cuales se encuentran

\footnotetext{
${ }^{59}$ Paula Soto Villagrán, "Espacio, lugar e identidad," en Mujeres y hombres en el mundo global. Antropología feminista en América Latina y España, Coords. Carmen Gregorio Gil y Martha Patricia Castañeda Salgado (México: Siglo xxi editores, 2012), 294.
} 
el comedor, la cocina y una habitación para guardar las mochilas o bolsas durante la noche, ya que está prohibido llevar cosas personales a los dormitorios.

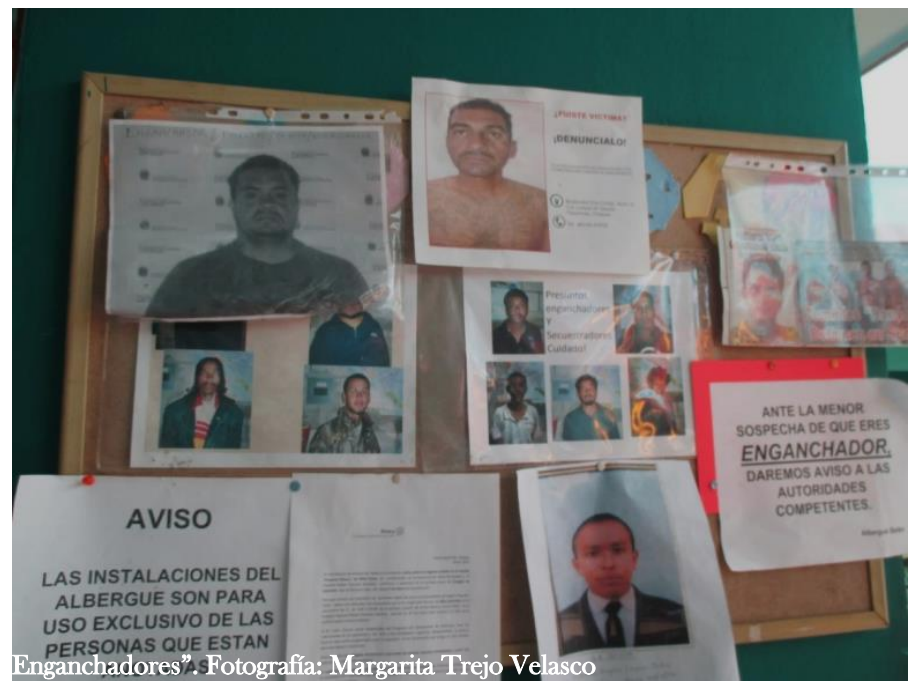

En esa planta están las habitaciones para mujeres, transexuales y familias con bebés, baños exclusivos para ellas, así como el dormitorio de la persona encargada del albergue por las noches. En el patio se encuentran los lavaderos y baños mixtos. La segunda planta está asignada para los hombres, con tres habitaciones muy amplias equipadas con literas, baños con regaderas y una cámara de vigilancia.

Ahora bien, el personal que colabora en el albergue consta de la coordinación por parte de Irmi y Flor María, tres encargados de la recepción: Julber, Ricardo y Carlos, quienes se turnan horarios; Mónica es la cocinera, José el médico general, Ángel el dentista y Jesús el encargado del mantenimiento del lugar. Tuve la oportunidad de convivir con cada una de ellas/os, con quienes me siento muy agradecida por el trato y apoyo brindado.

La dinámica del albergue la definiría de la siguiente manera:

El horario para levantarse es a las 6:00 am, misma hora en la cual se abre el albergue. Las y los transmigrantes limpian el lugar por dentro y por fuera. A las 8:30 se sirve el desayuno y el almuerzo-cena a las 17:30. Siempre se piden voluntarias/os para diversas funciones como, la preparación del desayuno y almuerzo, hacer la oración antes de comer y para la limpieza del comedor. 
A lo largo del día Mónica entrega productos para lavar ropa y sirve fruta. Las consultas médicas se llevan a cabo de lunes a sábado por las tardes y las consultas con el dentista se dan tres veces por semana. Durante mi estancia pude percibir que la gente ocupa en gran medida ambos servicios.

Entre 19:30 y 20:00 se debe pasar a la ducha que es obligatoria, a las 21:00 se cierra el albergue y a las 22:00 se apagan todas luces.

El médico brinda pláticas informativas acerca del VIH una vez por semana, mismo día en el cual realiza pruebas para detectarlo de manera voluntaria. Flor María da pláticas de trata de personas una o dos veces por semana. Los viernes por la tarde ofrece una misa en un espacio dedicado a ella dentro la casa de Flor María que está junto al albergue, igualmente la asistencia es voluntaria.

Ocasionalmente llegan personas a brindar diversas pláticas bajo previa autorización de la coordinación; tuve oportunidad de escuchar una por parte de la Asociación de Alcohólicos Anónimos y otras más de estudiantes universitarias quienes les explicaban los derechos y obligaciones que como migrantes tienen en territorio mexicano.

Algunas personas se acercaban ofreciendo trabajo a migrantes, acercándose a ellos de manera privada o llamando en grupo a cierta cantidad de hombres para apoyar en trabajos relacionados a albañilería, mecánica, construcción, pintura o recolección de fierro viejo. Solamente una ocasión vi a una mujer que buscaba a mujeres para trabajar en la limpieza de una casa y para cuidar de un enfermo.

Otras visitas que llegan con frecuencia son de periodistas e investigadoras/es. Durante mi estancia se presentaron personas de Human Rights Watch para hacer un estudio de las condiciones del albergue; y Benji, una joven de Serbia, presentándose como periodista mexicana pero en realidad era una estafadora, puesto que ofrecía credenciales de gente mexicana muerta por un precio difícil de pagar y por anticipado, no fue denunciada. 
Alrededor hay dos sitios de internet y un pequeño comedor económico, en el cual almorzaba, manteniendo buena relación con Hilda la propietaria; este espacio se convirtió en mi lugar de lectura y de descanso, aunque algunas de esas pausas iban acompañadas de conversaciones con transmigrantes.

También se pueden encontrar tiendas donde adquirir cosas básicas tales como, papel, jabón, alimentos enlatados y el servicio de llamadas telefónicas a Centroamérica.

Este fue mi hogar, mi espacio de trabajo, mi refugio como el de muchas personas con quienes además de una constelación de experiencias, como lo menciona Jone Hernández ${ }^{60}$, compartimos la mirada que incluye el ser mirada/o, la escucha que incluye a quien habla y la narración como ejercicio cooperativo, como acto colectivo, recopilatorio de diferentes voces, muchas de ellas plasmadas a continuación.

60 Jone Hernández García, "La autoetnografía como habitáculo," (seminario en el marco del proyecto Etnografiando prácticas de resistencia, 2012), 19. 


\title{
Capítulo 3. Habitando el viaje
}

\author{
"Because I, a Mestiza, \\ Continually walk out of one culture. \\ And into another, \\ because I am in all cultures at the same time, \\ alma en dos mundos, tres o cuatro, \\ me zumba la cabeza con lo contradictorio. \\ Estoy norteada por todas las voces que me hablan simultáneamente”
}

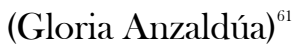

Debo confesar que al regresar del viaje, la tarea de transcribir el diario de campo me causó una gran impotencia, una sensación de extrañeza por no sentirme lista para enfrentarme a releer mi propio diario. Después de varios días, lo leí con lágrimas y risas que danzaban a lo largo de la lectura. Me preguntaba constantemente como pude estar tan tranquila al escuchar algunas historias tan duras, al experimentar tantas e-mociones compartidas. No me explicaba como en esos momentos la serenidad estuvo tan presente y en éstos no podía estar sosegada. Era desgarrador el solo imaginar que algunas de las personas con quienes conviví podían haber sido deportadas, podían haber vuelto a lo que no deseaban, podían haber perdido algo en el camino, una pierna, un brazo...podían estar sin vida.

Pero a la vez me sentía acompañada, era como si al leer sus historias esas personas estuvieran conmigo. Al leer la frase de José, transmigrante hondureño quién dijo 'por unos pagamos todos, por eso es bueno contar diversas historias para que la gente nos reconozca como seres dignos, que lo único que buscamos es una vida mejor', encontré el impulso para la transcripción.

Hanna Arendt lo afirmó 'No es el actor sino el narrador quien acepta y "hace” la historia ${ }^{{ }^{62}}$. Es a través de las historias contadas cómo el protagonista de las acciones se identifica, se reconoce y recibe lo que se denomina una identidad narrativa. Hay diversas maneras para dar cuenta de dichas identidades, para "hacer historia” en conjunto, en este trabajo he decidido plasmar lo vivenciado con cinco personas, no sin tensión, tomando en cuenta el tiempo compartido y el compromiso de contar sus tramas de vida específicamente en este

\footnotetext{
61 'Porque yo, una mestiza, continuamente pasando de una cultura a otra, porque soy parte de todas las culturas al mismo tiempo...' Anzaldúa, Borderlands/La Frontera, 77 [traducción mía].

${ }^{62}$ Hanna Arendt, La condición humana, Trad. Ramón Gil Novales (Barcelona: Paidós, 2005), 18.
} 
trabajo. Describiendo y construyendo lo sucedido, ya que como lo dice Butler, siempre estamos en proceso de construcción de discursos. 'Descripción y construcción suceden en el mismo momento ${ }^{93}$.

\subsection{La llegada}

El acuerdo con Flor María era que le llamaría por teléfono al llegar a Chiapas, para juntos organizar mi estancia. Para mi sorpresa, no recordaba mi proyecto y solicitaba que lo enviara nuevamente, lo cual me desilusionó, así que decidí ir a Tapachula y presentarlo personalmente.

Antes de viajar me enteré de la presencia del virus Chikungunya ${ }^{64}$, lo cual me causó mucho asombro ya que la presencia de ciertos animales era algo que no había contemplado como posibles riesgos o limitaciones en mi trabajo, sin embargo, tuvieron un papel dentro del mismo.

El viaje en autobús de San Cristóbal a Tapachula duró nueve horas (normalmente son siete). Pasamos por continuas revisiones de instancias migratorias (siete en total), las cuales consistían en inspeccionar identificaciones y algunas veces los equipajes, sin embargo, no lo hacían con todas las pasajeras/os, en tres ocasiones se las pidieron solamente a dos hombres y una mujer que no viajaban juntos, de los cuales los puntos que percibí en común fueron, el color de piel (más obscuro que el de las demás personas), la forma de los ojos (más rasgados), tenis y mochilas negras; este suceso me recordó el estudio de Jason de León ${ }^{65}$ donde refleja la importancia de las cosas que llevan consigo las y los transmigrantes, ya que pueden ser muy útiles, convirtiéndose en una tecnología, pero a su vez, pueden ser un factor de señalamiento como migrante.

\footnotetext{
${ }^{63}$ Butler, Violencia de Estado, guerra, resistencia, 71.

${ }^{64}$ Este virus es muy similar al dengue y se transmite mediante las picaduras de mosquitos que están presentes en las zonas más calurosas de la región, siendo Tapachula el primer lugar.

${ }^{65}$ De León, "Better to Be Hot than Caught", 477-495.
} 
La manera de revisar, la elección de a quien hacerlo o no, mostraba un fuerte aspectismo ${ }^{66}$, el nombre, apellido y las cosas que llevan consigo, pueden exponer a las y los transmigrantes que cuentan con los medios para viajar por autobús, a la arbitrariedad de las múltiples revisiones, algunas veces violentas y cada vez más recurrentes y especializadas.

\subsubsection{Tapachula}

Como llegué tarde decidí quedarme en un hotel. Al llegar, encontré a una pareja con un bebé esperando para registrarse y mientras bajaba mis cosas del taxi escuché el precio de la habitación; cuando fue mi turno el precio que me ofertaron fue el doble, cuando pregunté la razón, la respuesta fue: 'A ellos les di una habitación muy sencilla, sin tele ni baño adentro, a ti te daré una más bonita con tele y baño, porque para una mujercita, jpeor si viene sola!, el salir al baño en la noche pues como que no civerdad?, aunque aquí no pasa nada, pero así estarás más cómoda y segura güerita ${ }^{67}$. Le manifesté mi desacuerdo no solo en relación al precio, sino a la idea de que efectivamente una mujer viajando sola no está exenta de correr peligros, pero esos riesgos se deben a varios factores que no deberían ser exclusivos para las mujeres. El recepcionista me dijo inmediatamente 'ya bueno, pagarás lo mismo que ellos' con una expresión de fastidio.

Esta fue la primera impresión de llevar a cabo el trabajo de campo en un espacio de riesgo bajo la corporalidad femenina, viajando sola y con una diferencia en cuanto al color de piel. Al instalarme, revisé nuevamente el material para la intervención en crisis, el cual contrariamente a lo que había imaginado solo lo utilicé una vez en una entrevista con un joven, rompiendo uno de mis estereotipos, puesto que pensaba que al contar parte de sus historias de vida muchas personas necesitarían apoyo para recobrar serenidad, sin embargo, las personas con quienes conviví me demostraron una fortaleza muy potencial.

\footnotetext{
${ }^{66}$ Este término alude a la discriminación y el trato diferenciado con base en el aspecto de las personas, es decir, 'la imagen que para la mirada fugaz presenta simultáneamente elementos de la edad, género, clase, etnia, entre otros elementos'.

Tania Cruz Salazar, "Racismo cultural y representaciones de inmigrantes centroamericanas en Chiapas," Migraciones Internacionales 6, no. 2 (julio-diciembre, 2011): 141.

${ }^{67}$ Güerita/o, es la expresión que se usa para nombrar a personas con cabello rubio o de piel más clara.
} 


\subsubsection{Albergue "Belén"}

Sentí una gran alegría cuando vi la entrada del albergue. Gaby, una persona transexual hondureña fue quien me recibió con una gran sonrisa. Irmi llegó y posteriormente Flor María apareció, dándome la bienvenida en italiano me dijo que era una sorpresa verme así, porque esperaba ver a una mujer más madura y avanzada en años; después me preguntó acerca del viaje, solicitando a su vez apoyo a Irmi para buscar un espacio que fungiera como mi oficina. Le comenté brevemente del viaje y que en realidad no necesitaba una oficina, al menos no de momento, puesto que tenía que ver como se desarrollarían los encuentros con las personas, sin embargo, lo que me parecía fundamental era definir la logística de mi estancia. Flor María me dijo que podía quedarme en el albergue.

Me instalé sintiendo mucha confianza en la habitación asignada, aun cuando ronrones ${ }^{68}$, chinches (las cuales me picaron provocándome una alergia bastante notoria en la piel) y cuijas fueron mi compañía por las noches.

Tenía muy presente la idea de Marc Augé citado por Soto ${ }^{69}$ quien habla de los "no lugares”, los cuales se caracterizan por la circulación acelerada de personas y bienes, donde las transacciones e interacciones se producen entre individuos anónimos, ahora bien, considerando las nuevas reconceptualizaciones que desde la perspectiva de género se han venido desarrollando en torno al tema del espacio, esos "no lugares" pueden ser escenarios para repensar en la alteridad y reposicionarse, tomando en cuenta la multiplicidad de las identidades interactuantes. Esa habitación dentro del albergue, se convertiría en una parte importante de mi trabajo, tendría algo de "no lugar” pero a su vez representaría ese escenario estratégico que de alguna manera me situaría ante la población transmigrante.

\footnotetext{
${ }^{68}$ Los ronrones son una especie de escarabajos.

${ }^{69}$ Soto Villagrán, "Espacio, lugar e identidad," 294.
} 


\subsection{Tejiendo tramas en compañía}

“Necesitamos emancipaciones plurales a violencias plurales" (Lorena Cabnal, 2015)

Hay muchas cosas que se quedan fuera en el intento de contar ideas y emociones lingüísticamente, sin embargo, este es un esfuerzo por plasmar narraciones de personas nómades, siguiendo una de las aportaciones de Rosi Braidotti y la lectura que yo hago de la misma a partir de una conferencia impartida en Bolonia en mayo del 2014, en donde se nombra como acción nómade a la subversión de convenciones establecidas, a la conciencia crítica que se resiste a establecerse en identidades fijas, en modos de vida instaurados por la sociedad; esto no precisamente mediante el acto de viajar, aunque si bien en este texto el moverse de sitio da fuerza a dicha acción nómade.

\subsubsection{Historia de Armando}

Armando, es un joven hondureño, serio, constantemente con un temblor en las manos, se presentaba como mayor de edad, usando siempre suéteres y gorra a pesar del fuerte calor. Fue él quien solicitó hablar conmigo, me dijo que al llegar al albergue tenía mucho miedo porque era la primera vez que entraba en un lugar así y no sabía que esperar, si era un espacio seguro o no, si podía confiar en la gente o no, además nunca había salido de su país por lo cual estar en México representaba un reto. Agregó que varias personas en el albergue le comentaron que yo soy psicóloga, que estaba trabajando en una tesis en la cual hablaría bien de las y los migrantes, así que me observó varias horas, dándose cuenta de que podía confiar en mí para contar su historia, en parte para desahogarse y en parte para que de alguna manera se transmitiera a los jóvenes en Honduras. Me transmitió mucha nostalgia y para mí, su mirada podía decir más que mil palabras, lo cual no se puede reflejar aquí, pero este es un intento por contar parte de su historia:

'Tuve que escapar de Honduras porque formaba parte de la MS18 ${ }^{70}$ (al decir esto se descubrió el brazo mostrándome un tatuaje con el símbolo de dicha organización), tienes

\footnotetext{
${ }^{70}$ Mara Salvatrucha, abreviada como MS, Mara 18 y MS-13 son organizaciones internacionales de pandillas criminales asociadas, que se originaron en los años 80’ y 90’ en las calles de Los Ángeles, California. Se han expandido a otras regiones de Estados Unidos, Canadá, México, Guatemala, El Salvador, Honduras y España. La mayoría de las pandillas están integradas por personas centroamericanas y se encuentran activas en zonas
} 
que huir sino no te dejan irte así nomás, una vez que entras es difícil o imposible salir, pero yo ya no podía más por eso escapé, huyendo como animal. La verdad ya lo venía pensando desde hace tiempo pero tenía muchísimo miedo de las represalias en contra de mi familia, pues más por mi mamá... ésos saben darte donde más te duele y pues madre solo hay una ¿verdad?, quería traérmela pero no podía, más bien ella no quiso, porque allá tiene su casa, está mi abuela, así que viajo con mis hermanos, dos son menores de edad y uno mayor. Fue después de una riña entre maras que supe que ya no podía más... A los chicos no sabía si traérmelos, pero eso si me pidió mi mamá, me dijo "hïjo yo no creo que a mí me hagan algo o a tu abuela, ya somos mayores, pero a tus hermanos si llévatelos, a esos sí que pueden meterlos en sus asuntos, como a ti y eso sí que no quiero" y pues yo debo cumplirle’.

Los errores se pagan caro, yo me metí porque quería conquistar a una muchacha, la impresionas si tienes poder, si la gente te tiene miedo, o si te ven con un pistolón, sino ni te voltean a ver, al menos en mi pueblo de Honduras es así, además que puedas tener acceso a las drogas te hace ver bien también, aunque no las consumas, pero se sabe que la mara pues maneja mucha droga, se piensa que siempre se les regala a todos los del grupo pero no es así, en fiestas de los jefes sí, todos podemos probar un poco gratis, pero no siempre nos invitan a todas las fiestas, ya sabes hay rangos ahí también como en el ejército jaja. Pero pues ahora ni tengo quien me quiera, porque si conquisté a la chava que quería pero me duró poco el gusto, la condenada mejor se fue con otro y aquí me tienes, temblando por el miedo de que sepan dónde estamos, que le hagan daño a mi jefecita ${ }^{71}$, nos agarre la migra o nos pase algo....De verdad que creo que estoy pagando caro, desde que entré sentía que no era para mí, que no duraría mucho, sabía que sufriría más de lo que podía disfrutar...pero quería sentirme parte de, como un chavo bien valiente que no le teme a nada.....'

urbanas y suburbanas de dichos países. Las y los integrantes de estos grupos pueden ser reconocidos por su lenguaje oral y de señales, así como por una gran cantidad de tatuajes, aunque actualmente esta característica está siendo modificada para ser menos reconocibles. Han cobrado protagonismo en el trayecto migratorio puesto que se dedican a actividades ilícitas tales como el narcotráfico, secuestros, extorsiones y trata de personas, para las cuales las personas transmigrantes representan una fuente importante de víctimas.

Para mayor información consultar: Samantha Howland, "Migra y Maras" (tesis fin de máster, Universidad de Georgertown, 2014), https://repository.library.georgetown.edu/handle/10822/709745.

${ }^{71}$ Jefecita es la manera coloquial de nombrar a la madre en el contexto mexicano y centroamericano. 
Durante todo el relato hubo pausas de silencio muy grandes, las cuales favorecieron la escucha.

'Mira si participé en cosas malas pero nunca maté a nadie, yo me encargaba de organizar las cosas que llegaban, desde drogas, armas, hasta los que secuestraban, pero nunca les hice nada, cuando a alguno de ésos no le pagaban el rescate los mataban y yo llevaba las bolsas negras con sus huesos a tirarlos al río o a esparcirlos por el puente, para que no se reconocieran sus restos, pero por Diosito que yo no los mataba, ni les veía la cara siquiera.... Osea que sé que fui un delincuente pero no un asesino, yo cumplía las órdenes que me daban porque había funciones para todos, pero desde el inicio sabía que no me tocaría pegarle un tiro a nadie, ni tampoco acercarme mucho a la gente, más bien, me encargaba de cosas sencillas, como en otros trabajos y muy de vez en cuando iba a sus fiestas, porque también sino vas pues te castigan... Ahí tampoco violé a ninguna chica, en esas fiestas hacen de todo y no solo con las mujeres, pero yo de verdad que no quería hacerle daño a la gente'.

Esta conversación hizo eco en mi mente al término acuñado por Hanna Arendt la 'banalidad del mal' ${ }^{72}$.

Posteriormente me comentó que no había sido completamente honesto conmigo, al decirme su edad había mentido porque 'el cambiarte de edad sirve, más si eres menor, sino es que te pueden detener porque dicen aquí que no deberías viajar solo sino tienes 18 años, pero ese es solo un número, no significa que no puedas ser responsable de ti mismo, pero bueno, para que en dado caso de que la migra me agarre diré que tengo 19 y por si piden testigos, a todos les digo que tengo 19'.

'Mi intención es quedarme en México un tiempo, hasta que se calmen las cosas y pueda regresar a mi país con mis hermanos, no al pueblo, a otro lugar donde podamos empezar de nuevo con mi jefecita y mi abuela. Pero ahora lo mejor es estar lejos y ya me dijeron que puedo pedir refugio aquí a la COMAR, ya empecé hacer el trámite, de verdad que necesito el apoyo porque huir de la mara no es cualquier cosa. Pienso que si me dan ese refugio

\footnotetext{
${ }^{72}$ Arendt acuñó la expresión «banalidad del mal» a partir del análisis en el proceso de Adolf Eichmann por su participación en el régimen nazi. Lo usa para expresar que algunas personas actúan dentro de las reglas del sistema al que pertenecen sin reflexionar sobre sus actos; no se preocupan por las consecuencias de sus acciones sino por el cumplimiento de las órdenes, es entendido como un fenómeno de falta de juicio. Hanna Arendt, Eichmann en Jerusalén, Trad. Carlos Ribalta (Barcelona: Lumen, 1999).
} 
también puedo traerlas, mis hermanos y yo podemos trabajar aquí y rentar una casita, tal vez ahorrar y comprarse algo allá en Honduras en un tiempo...a lo mejor en unos años ya se detiene a la mara y ya no habrá tanto peligro, o a lo mejor se hayan ellas aquí y ya no se van a querer ir, acá está rebonito y trabajo hay'.

'Estos días me he enterado de lo difícil que es llegar al norte, pa' que, ni hablo inglés y estaría más lejos de mi familia, hay que atravesar muchos retenes, la migra está por todos lados, mi hermano chiquito sí que se quiere ir, pero yo le digo que no, que ya bastante hemos logrado con estar aquí, para que arriesgarse más...como me dijeron que hasta para ir a la COMAR tienes que tener cuidado de que no te agarren, imagínate si nos vamos más lejos, yo creo que hasta la mara me podría encontrar si me voy por esos caminos, ya se sabe que andan agarrando a la gente, imagínate si me reconocieran, porque esa gente tiene sus contactos...por eso incluso aquí no dejo que se vean mis tatuajes y mi cara pues poco, estoy seguro que maras deben pasar por aquí también, por eso no dejo que mis hermanos hablen mucho....mira cuando viajas con más personas, hay que planear bien lo que se va a decir, deben tener una historia más o menos verídica pero no contarlo todo, no sabes con que gente te relacionarás y la información que cuentes puede ser usada en tu contra; ya sea si te detiene la migra, si te cruzas con gente mexicana, mira, jcomo contigo!', si estás en el albergue o en el hospital. Tu meta siempre debes tenerla clara individual y grupalmente. Para alcanzarla hay que fingir a veces, aunque a veces te gustaría mostrarte tal cual, pero huir cruzando lugares desconocidos no es fácil’.

Por eso digo que estoy pagando caro, metiendo a mi gente de por medio, aunque bueno, mis hermanos pequeños ni se preocupan tanto, están como niños con juguete nuevo, como si estuvieran de paseo, yo vengo con tantas cosas en mi cabeza, con tanto miedo y ellos, bajando fruta de los árboles, riéndose de como habla la gente aquí.. me enojaba al inicio, porque no se estaban quietos y no se daban cuenta de lo peligroso que era este "paseo", mi hermano mayor también estaba muy asustado, pero por eso es mejor que ellos estén relajados, así no llaman la atención, si la migra los ve se darían cuenta luego luego que son menores de edad y no quiero que nos separen, eso sería el peor golpe, ahora son mi completa responsabilidad, es como si yo fuera acá la mamá’. 
'Pienso mucho en el dicho "en la mara entra si quieres, sal si puedes", en Tegucigalpa quien manda ahora es una mujer de 63 años, es la veterana a quien más respetan, es la que entrena a las pequeñas y se sabe que tiene varios contactos en las fronteras, para juntar gente, más mujeres que pasen la droga al otro lado, por eso es que me da miedo que me encuentren aquí, todavía estoy por la frontera y la verdad hasta caminar por la calle me da miedo que algún marero me reconozca’.

'Comparto todo esto, para que si alguna vez alguien lee esto o se enteran de estas historias en Honduras, sea como una advertencia, para que no se involucren en la mara o grupos delictivos, puede parecer divertido, desafiante pero al final es un círculo vicioso que no te deja en paz, que te puede matar, te deja marcado, y si quieres salir tendrás que enfrentarte con muchas cosas y con un grupo que te ve como parte de, pero no como persona....yo espero que algún día pueda dormir tranquilamente, pueda ir por la calle sin tener miedo, pueda tener una vida normal como la de los demás'. 


\subsubsection{Trama de Daylin}

Daylin es hondureña, transexual, de veintitantos años como le gusta decir, actualmente está bajo tratamiento hormonal con resultados visibles, lo cual la tiene muy contenta; ya cuenta con la visa humanitaria, lleva 8 meses en territorio mexicano, específicamente en Tapachula y su destino es llegar a la Ciudad de México.

Con ella la convivencia fue muy constante de manera individual y grupal. Los relatos aquí resumidos, estuvieron acompañados de lágrimas, risas, del consumo de frutas muy variadas, de experimentos de las técnicas de belleza que había aprendido apenas y que ponía a prueba conmigo, de sus cuidados con relación a la alergia que se me desarrolló, de regalos y de abrazos.

'Yo era prostituta en Honduras, me vestía de mujer para sentirme como realmente soy, éramos varias y nos acompañábamos, nos protegíamos, algunas trans y otras no; nos vigilaba la mara y se dieron cuenta de que yo era una líder dentro del gremio, por eso me reclutaron'.

'Antes de eso, por las mañanas me vestía muy machito, trabajaba en una maquila y me drogaba mucho, porque era mi escape...cuando comencé en la prostitución era como tener otra vida, así libre, deje las drogas y estaba tranquila la verdad. Cuando entré en la mara me dieron una paliza durante 13 segundos en los que te patean todos los miembros del grupo presentes, es parte del ritual para entrar, es la prueba, como aguanté me pasaron como "burra”, en total éramos seis burras, osea que éramos las que teníamos que ir a los puntos estratégicos para vender la droga, habían otras encargadas de los clientes, los seducían y los llevaban contigo, después tenías que ir a "la casa" para entregar todo el dinero de las ventas, sino paliza segura. Varias veces me pasó, me dieron palizas de las buenas porque en las mismas fiestas que organizan los jefes te vuelven adicta, te obligan a consumir para "estar en la fiesta” y claro, después esa mierda se convierte en tu adicción, la tienes a la mano... te sientes bien, más cuando estás en un grupo donde no te rechazan por ser como eres, es más, eres útil así.

'Cuando mi familia me veía, lloraban, me preguntaban si tenía SIDA, me daba tanto miedo decirles que eran drogas, eso me preocupaba más que hablar del SIDA... después mi hermanita de 22 años murió por esa maldita enfermedad y yo me puse muy mal, ;hasta le 
robé dinero a la mara para pagar mis drogas!, eso te convierte en una "peseta” osea da luz verde para que si otros miembros de la mara te atrapan, te maten si tratas de huir y te tiren en cualquier parte por traición. Esa vez no me hicieron nada, porque yo estaba muy mal, es más me convirtieron en madrota, así que yo tenía que convencer a gente del gremio para entrar, no solo gais o trans eh, a todos parejo. Pero yo me cansé de la situación y decidí dejarlo, me cansé de todo, por todos lados te sale el peligro, con los clientes, con las otras pandillas, con la policía, con tus jefes, uf... te obligan a meterte con ellos en las fiestas, hacerles todo lo que te piden en el plano sexual, aunque se digan que son muy machitos, te piden cosas que hacen dudar de su virilidad, a veces te forzan con golpes, sobre todo cuando estás muy drogada, pues ya no sabes bien como actúas, eres más lenta en todo, yo solo quería dormir.. pero recibí la última golpiza que me hizo reaccionar. Así una noche travestida y todo, con 400 dólares de la venta de droga agarré para Guatemala y de ahí me vine para acá. Para escaparte hay que salir en la madrugada, yo salí de Honduras a la 1:00 am, porque se queda como pueblo fantasma y es cuando puedes despistar más. Además así no tienes la tentación de ir a despedirte de tu familia o amistades, arriesgando tu proyecto de huida, porque si te despides mmm, sufres más?.

'Una vez que llegué a Guatemala tomé la combi para venir acá, todo iba bien, pasamos por dos retenes, hasta que en uno, una vieja de la migra me observó y me pidió que me bajara, ushh fue por su culpa que me agarraron, los otros oficiales me habían visto sin decir nada, pero esa mujer fue la culpable, me veía como con asco, yo creo que es una racista. Cuando me agarraron, me castigaron un mes porque mentí con mi nacionalidad y también di un nombre falso, por eso si te agarran es mejor decir los datos reales. Me trataron muy mal en la oficina de INM, me decían de cosas, me miraban feo, yo no dije nada porque cuando viajas, sobre todo la primera vez, no conoces tus derechos como migrante, pero los tienes y saberlos te hace estar empoderada.... Fíjate primero me trasladaron con los hombres pero me iban a hacer trizas, desde que entré lo supe; no sabían dónde meterme, así que decidieron llevarme al sector de familia, donde me apodaron la "señora de la casa”, porque para no aburrirme, después de días ahí pues me puse a hacer cosas de limpieza, también para no caer en depresión. Tu comportamiento importa, la humildad y respeto las debes mostrar en cualquier lado....al inicio no quería comer, salir de mi habitación, levantarme, bañarme, nada, solo pensaba en mi abuelita y en cómo le haría ahora para tener dinero, porque yo era 
quien le mandaba más pisto ${ }^{73}$, ella ya está muy viejita, no puede trabajar y de mis tíos pues algunos ayudan, otros no, pero para mí es como mi madre, por eso sabía que tenía que ayudarle. Cuando me metí a la mara casi no la visitaba para no ponerla en peligro, aunque vivía lejos de donde estaba el grupo y de dónde yo vivía, pues siempre fui cautelosa con eso... no me hubiera perdonado nunca si algo le hubieran hecho, ay no, de verdad que no quiero ni pensarlo, sabiendo de lo capaces que son, de las atrocidades que hacen, más si están muy drogados, es que no se tientan el corazón, si es que lo tienen... las últimas veces estando allá cuando le llamaba me pedía que por favor le enviara dinero, que ella sentía que no andaba en buenos pasos, que por favor me cuidara, que no la olvidara, porque yo soy su mayor sostén...'

'El estar activa, ayudar a la gente, limpiando o haciendo lo que sea, son las cosas que puedo decirte que me han ayudado en este proceso'.

'Decidí hacer el trámite para solicitar el refugio aquí, así que bueno estuve en el $\mathrm{DIF}^{74}$, en este albergue unos días, luego en el Buen Pastor buen tiempo la verdad y ayudaba a vender pan, ahí me la pase muy bien. Fui a la COMAR para meter mis papeles, tienes que decirlo todo, nombres, señas, fechas, símbolos, describir tatuajes, todo para que crean tu historia, para que te ayuden con el visado...yo tenía mucho miedo al inicio de decir detalles, porque es información muy valiosa que podía ponerme en peligro, esa gente tiene buenos contactos por todos lados, así que si los capturaban podían pensar que era por la información que yo di...pero también quería la visa y la protección, así que dijje todo, sin pelos en la lengua. Ahí en la COMAR me hablaron de ACNUR, fui y ellos me apoyaron mucho, me dieron dinero para alquilar un cuarto temporal, un papel con el que pude buscar un trabajo de medio tiempo, me pagaron un curso de estética, te ofrecen varios, yo me decidí por ése... Mira, te enseño mis diplomas y aunque no tengo todas mis herramientas aquí puedo pintarte las uñas, hacerte algún peinado, así mientras platicamos tú avanzas con tu tesis y yo practico’.

\footnotetext{
${ }^{73}$ Pisto, es como se le llama al dinero coloquialmente en Honduras.

${ }^{74}$ Sistema para el Desarrollo Integral de la Familia, es una institución pública mexicana de asistencia social.
} 
'Después de siete meses me dieron la visa. Luego me enteré de otras siete transexuales que huyeron también y están en el $\mathrm{DF}^{75}$ y Puebla haciendo el mismo trámite, por eso es que me quiero ir para allá, para estar con ellas. Acá en México la gente es más abierta y ser homosexual no es visto como castigo, pero como me cuentan en el DF se ven todavía más, ¡hasta te puedes casar! así que me parece más interesante... Fíjate que la mara tomó represalias contra un grupo de defensoras de las trans en Honduras, después de que tantas nos escapamos, y como saben que estamos en México, pues creo que eso es lo que podría poner en riesgo mi vida, la verdad ahora, es lo único que me parece más complicado porque teniendo ya la visa pues no pueden correrme del país como a otros, puedo trabajar y andar en la calle sin problemas, desde que entré aquí me siento más protegida, es tan diferente a Honduras y El Salvador, ¡de verdad!, mucha gente piensa que la solución para que la violencia se vaya es matar a toda la mara, es cruel decirlo, pero así de crueles son ellos, mira que yo estuve ahí, bien adentro, hay gente que no es mala, como yo... participaba con ellos pero casi por obligación y te lo digo así, mandarlos al otro mundo sería la solución... Bueno, cambiemos de tema, le he llamado a mi abuelita y le mande dinero dos veces, está contenta de que acá la gente sea más tolerante; ahora me preocupa un poco que no le he mandado más dinero, pero es que como pensé que si me iban a dar el traslado pronto y en el DF comenzaría a trabajar, dejé mi trabajo aquí y por eso me vine otra vez al albergue, porque me dijeron que en un par de días me llevarían del ACNUR, mira llevo ya cuanto aquí y nada'.

'De las estrategias como las dices tú, para este trayecto yo te diría que hay que aprender las palabras mexicanas, las expresiones que se usan aquí y hasta el modito de hablar. Hay tanta gente variada en su aspecto aquí en tu país que puedes decir que eres de otro estado y te lo creerán, siempre y cuando modifiques tu hablado, ni la migra se dará cuenta si hablas como mexicana. Otra cosa importante es estar bien alerta, debes fijarte bien cómo se desarrollan las cosas en los lugares a los que vas, el albergue por ejemplo, identificar que gente podría apoyarte, a cuales es mejor evitar, desde los que vienen a ofrecer "trabajo". Por ejemplo el chico nicaragüense se va cada mañana en la camioneta blanca y regresa al poco rato, es porque el hombre le paga por sexo 200 pesos cada tirada, yo lo he observado y sé que no es gay, pero por dinero se hacen muchas cosas, me contó que al inicio lo hacían con condón, pero después el tipo le ofreció pagarle 200 pesos más cada vez que lo hicieran sin condón; ya

\footnotetext{
${ }^{75}$ Distrito Federal, capital y sede de los poderes federales de México.
} 
le dije, pues así sacas tu dinerito pero también SIDA papito... ayer un hombre en su coche se paró a hablarme, me estaba invitando a dar la vuelta, por un helado, un café, para enseñarme la ciudad, yo le dije que no... al poco rato apareció otra vez y me llamó, esta vez ya me preguntó directamente cuanto le cobraba por mis servicios sexuales, jme ofrecía 500 pesos! la verdad dudé si aceptar o no, porque necesito dinero, pero luego pensé que irme en su coche a quien sabe dónde y por cuánto tiempo, ay no, que tal me botaba quien sabe dónde, golpeada o muerta, o que tal me deportaba... Por eso hay que tener cuidado incluso aquí en el albergue, la gente local como sabe que estás generalmente sin dinero, ni trabajo, sin papeles, pues se aprovecha y te puede ofrecer muchas cosas, igual te va bien pero también te puede ir mal; saben que tú estás necesitada/o y ellos no, tú estás en su territorio. Por eso "aguas" con las ofertas que te lleguen y aceptes. A mí no me parece que este viaje sea más peligroso si viajas siendo mujer u hombre, o como yo, creo que si se presenta peligro es para todos y violaciones sexuales por ejemplo la pueden sufrir hombres y mujeres, los golpes, los asaltos, extorsiones van igual para todos... por eso si eres hombre no debes confiarte tanto, si eres mujer no debes temer tanto. Bueno, esto me quedó como poesía’.

'En general te puedo decir que la gente mexicana que he conocido, a excepción de la gente de la migra, ha sido muy buena, muy respetuosa, siento que hay un trato diverso, no solo porque soy así, trans, bueno soy más mujer que muchas en realidad jaja, pero creo que la gente aquí si se preocupa por lo que te pasa, de verdad te escuchan cuando les cuentas cosas, no solo por el morbo de saber cómo es ser prostituta o tener sexo con un cuerpo como el mío, de verdad se interesan en tu persona....la gente que viene de otros lugares si me ve con esa mirada morbosa, no todos claro, pero de verdad siento que aunque seas del mismo país y estés en un lugar así, lejos del tuyo, no te van a ayudar sino les das algo a cambio o te van a ignorar porque eres gay, lesbiana o trans...en Centroamérica hay mucho racismo todavía desafortunadamente, porque es un país bonito, más por los paisajes que tiene cerca del mar, hay mucho turismo por lo mismo. De verdad la mara lo está destruyendo, no era tan peligroso, no era tan violento antes...veo las fotos de mi abuelita y se ve como un lugar pacífico, tal vez pobre o sin las casotas como en las novelas mexicanas, pero muy bonito...espero regresar algún día, pero al menos en dos o tres años no puede ser'. 
'Como ACNUR no da señales de vida con lo del traslado, me quedaré aquí un tiempo, hemos decidido buscar un cuarto y quedarnos los cuatro ahí (junto a Kimberly, Juan y Julio, transmigrantes que conoció en el albergue), una amiga nos va a contratar porque tiene un restaurante, no esperaba que encontráramos algo así tan rápido porque si pensaba irme pronto en realidad, pero bueno vamos a ver como se dan las cosas'. 


\subsubsection{Historia de Karla}

Karla, la enfermera catracha ${ }^{76}$, tal como le gusta que la identifiquen en espacio mexicano, es una mujer de 32 años, viaja sola y este es el segundo intento que hace para cruzar fronteras.

"Gertrudis cerraba los ojos cada vez que daba un sorbo a la taza de chocolate, pensaba que la vida sería mucho más agradable si uno pudiera llevarse a donde quiera que fuera los sabores de su casa materna" ${ }^{97}$.

Con esta frase fue como me presenté con Karla, ya que ella estaba leyendo el libro de Esquivel, el cual es uno de mis favoritos y por eso recordaba la frase casi de memoria. Esto de alguna manera rompió el hielo y por eso ella aceptó colaborar en este trabajo.

'Bueno yo me llamo Karla, soy orgullosamente catracha, esta vez vengo decidida a quedarme en tu país. Justo el año pasado intenté este viaje y llegué hasta el desierto ya para entrar a los EU, pero por una estaca que se me clavó en el pie me agarraron y ahí voy de regreso. Pero en ese viaje conocí a mexicanos, muy buenas personas y nos cambiamos datos, ahora me ofrecieron trabajo en una clínica en Veracruz y además cuidar de un pariente muy anciano. Tengo tres hijas y cada vez necesitan más y más, una también claro, si quieres ser alguien en la vida tienes que prepararte, pero todo cuesta, yo tengo la licenciatura en enfermería y algunos cursos más que me he sacado poco a poco, pero acá en México tienen cosas muy buenas, más en el DF y a veces más barato que en Honduras. Yo la verdad dije que iba a venir y si lograba pasar pues quedarme varios meses en Veracruz, ahorrar y regresarme, pero si se da algo en el DF también intentaría quedarme un tiempo, sobre todo sabes para que, para tomar cursos, en internet he visto varios que se ven geniales, se ve que la $U N A M^{78}$ es una súper escuela y además hay becas; no sabes cómo me gustaría ganarme una de ésas, ya sea para tomar cursos o para hacer una pasantía en algún hospital o laboratorio, o ser ayudante de investigación. Eso lo tengo muy claro, si en este viaje no puedo acceder a alguno de esos cursos u oportunidades académicas, lo seguiré intentando muchas veces hasta que lo

\footnotetext{
${ }^{76}$ Catracha/o, es el gentilicio de la gente de Honduras.

${ }^{77}$ Laura Esquivel, Como agua para chocolate (México: Editorial Planeta, 1989), 178.

${ }^{78}$ Universidad Nacional Autónoma de México.
} 
logre, no sé si te ha pasado pero cuando se te mete una idea en la cabeza, que además es una idea con diversas posibilidades, no se te va de la mente hasta que la cumples.

En este momento le compartí mi lucha por obtener la beca que gozo ahora, puesto que su sentir coincidía completamente con lo que yo había experimentado.

'Yo tengo un novio español que me estaba dice y dice de irme para allá, que seguro encontraré trabajo y que él me pagaría el viaje y todos los gastos; es una historia larga que comenzó hace muchos años, solo nos conocemos por internet pero sé que es un buen hombre, claro que tengo ganas de ir a verlo, conocer España e intentar trabajar allá pero ya tenía esta oferta desde antes, tengo ganas de vivir en México un tiempo y si de verdad puedo ganar un buen dinero, podría dejar algo en la casa y yo irme a España un tiempo. Ahora que si no puedo pasar, me deportan o algo malo sucede, pues me regreso a Honduras para armar bien el plan b, irme a España. Vengo con varias ideas en la mente, pero mi intuición no falla, ¿tú crees en la tuya?, deberías si no, porque te guía, yo esta vez siento que si lograré mi cometido y tendré una vida mejor, no sé cómo explicarte esta sensación de seguridad, espero que todo marche bien, confío en que así serâ.

'La vez pasada yo estaba muy nerviosa, era la primera vez que salía de mi país, todo era muy nuevo, no tenía una idea muy clara de cómo sería el camino, en fin, la intuición me hacía dudar y mira, no falló. El viaje anterior lo preparé sola, investigué y contraté un coyote desde Honduras, pero nunca lo vi porque todo era como muy secreto, le pagué una parte del viaje antes y el trato era que el pago final se lo daría una vez estando en $\mathrm{EU}$; esa vez mi intención era aprender inglés y trabajar, ahorrar, mandar dinero a mi mamá porque es quien cuida a mis hijas y pues porque es mi mamá, bueno conocer la cultura americana que es tan sonada por todos lados y por la cual mucha gente lo deja todo en sus países’.

'Viajé primero en bus hasta aquí, luego tomé otro bus para Arriaga y ahí agarré el tren, la famosa "Bestia". El riesgo en el tren es grande porque da frenazos inesperados, tienes que ser muy hábil para saltar, agarrarlo, correr, en un cabeceo puedes caerte, no ver una rama de árbol que te puede tirar y así perder una parte del cuerpo. Hay puestos de migración en el camino, por eso el saltar es una constante. Pero como va mucha gente conviene más, puedes decir algo o gritar para evitar que te agarren arriba y te quieran hacer algo. Muchos dicen que no es para mujeres, pero yo te digo, sé que puedo correr como cualquier otro, pude saltar 
del tren y volver a subirme cuando está en marcha... tenía miedo, claro que sí, mucho, pero cuando teníamos que correr vi a una mujer bien gordita que corría duro, ahí fue cuando dije, bueno si ella puede porque yo no. Hace rato escuché que te decían que las mujeres no deberían hacer un viaje como éste, pero no estoy de acuerdo, todos tenemos derecho'.

'Te voy a contar la historia anterior para que te des una idea del trayecto que hice. Mira el coyote que contraté como te dije no lo conocía, todo lo manejamos vía telefónica, la entrega de dinero era mediante envío, así no era necesario tener el contacto personal, yo confiaba porque me lo recomendó una persona de verdad de fiar y sabía que los tratos que hace son serios. El coyote solo me dijo un número que tenía que memorizar y que en el camino me contactaría una persona aquí en México, él ya sabía que yo planeaba viajar en el tren. Bueno pues cuando me trepé a "La Bestia” encontré curiosamente a dos compañeros de la primaria, nos reconocimos luego luego, aunque habían pasado tantos años sin vernos, entonces pues me junté con ellos, viajamos juntos casi todo el tiempo, solo una vez nos perdimos de vista, en una de las redadas de la migra, todos saltamos despavoridos y yo corrí y corrí, sola, después de un rato una señora me dio de comer y me dijo donde seguían las vías del tren para agarrarlo otra vez... Horas después ellos también se volvieron a subir, ahí me quedó claro que aunque podíamos acompañarnos en el viaje, en realidad migraba sola, cada uno tenía su propia meta y así lo veo esta vez también; puedes viajar acompañada pero en realidad es un viaje individual. Bueno después de días sin bañarse, sin casi comer, ni dormir, de repente un grupo detuvo el tren y pidió que bajáramos todos, empezaron a gritarme "colocha, colocha", yo no sabía que así le dicen aquí a la gente con el pelo rizado, entonces no hacía caso, hasta que uno dïjo "hondureña, morena” volteé a ver y efectivamente me hablaban a mí y me pidieron la clave, yo no entendía nada y uno me dijo, dinos el número que te dio el coyote, se los dije y me llevaron, luego supe que estaba con los del cartel del golfo ${ }^{z 9}$. Mira yo era la única mujer entre todos esos maleantes, entre todos los migrantes que nos llevaron, éramos ocho y no me hicieron nada, caminé con ellos, corrí con ellos, me escondí con ellos, lo único que no, era irme a los burdeles aunque me invitaron claro, pero les inventé que estaba embarazada y como que así no les servía mucho, entonces

\footnotetext{
${ }^{79}$ Es el grupo criminal relacionado a la droga más antiguo de México. Su red y alcance transnacional ha llevado al cártel del Golfo a tener conexiones en Europa, África, Centro América, Sudamérica y los Estados Unidos. Wikipedia, s.v. "cartel del golfo," consultada el 10 de agosto de 2015, https://es.wikipedia.org/wiki/C\%C3\%A1rtel_del_Golfo.
} 
no me invitaban nada... Iba con ellos a hacer compras de ropa y zapatos, porque íbamos a atravesar monte y desierto, entonces debíamos estar bien preparados, entendía ahora porque el pago al coyote jera tan caro! Pero la verdad nunca me trataron mal y por lo que vi tampoco a los otros, lástima que cuando llegamos al desierto se me ensartó esa cochina estaca y no podía caminar, apareció la migra y todos se echaron a correr, yo de plano ni me moví. Sé de uno de ellos que está en EU, ahora le va muy bien y me dice que lo intente otra vez con ese mismo grupo porque de verdad cumplen. Bueno por eso cuando te digan que una mujer no puede hacer este viaje, acuérdate de mí y diles que si se puede, además cuando te toca, te toca, seas lo que seas y estés donde estés?.

'Esta vez vengo más preparada psicológica y tecnológicamente. Traigo dinero para pagar un hotel, me puse a orar y me dije mejor me voy a la casa del migrante, porque encontraré algo, mi intuición y mi corazón me dijeron que viniera, al llegar a Tapachula tomé un taxi para venir al albergue, pero como a veces son ellos mismos, los taxistas que te llevan a deportar hay que ser más lista, por eso cuando el taxista me preguntó si era migrante, le dije inmediatamente que no, que venía a hacer una investigación para la universidad, unas entrevistas ;Ah, tomé tu papel!'

'Traigo estos zapatos para ir por el monte, el grupo que se fue tempranito me ofreció irme con ellos, se veían buenas personas pero uno nunca sabe y mi intuición me dijo que no me fuera y ves ya los atraparon. Ahora encontré a este hombre (se refería a un hombre salvadoreño, quien contaba con un permiso para transitar por territorio mexicano porque su visa está en trámite) y me va a ayudar, arriesgándose también, el plan es que vamos a decir que yo soy su esposa, voy a escanear su papel y debo poner mi nombre de alguna manera, así viajaremos en los autobuses de $A D O$ que parece que vigilan menos, porque como son más caros, pues menos gente los toma, así le vamos a hacer hasta que lleguemos a Veracruz, él sigue para arriba, así molestan menos también. De verdad que él me da buena espina’.

'Mira mi bolsa, es como la que usan ustedes aquí jverdad!... Yo me fijaba en las telenovelas, hasta mis hijas lo hacían, para ver la manera en que se visten las mexicanas, como se arreglan, como tienen el pelo, que zapatos usan, como se mueven, para viajar así, como ellas, como ustedes; también investigué en internet cosas del país y como tengo amigos mexicanos, les preguntaba frases que podía usar, ellos me dijeron que podía inventar que soy de Veracruz, 
porque allá la gente es más morena, así como yo, tienen un hablado diferente, entonces sería más creíble que soy costeña. Sabes que, el sentirte por ratos como que eres de otro país y que la gente te crea, es bien divertido...te hace hasta olvidarte a veces de las tristezas. Al inventarte, al hacerte pasar por alguien del lugar al que vas, crearte una historia, ya es un escape que te entretiene'.

'Otra cosa que te da fuerza es tener el contacto con tu familia, en mi caso nos hablamos todos los días con el WhatsApp y Skype, así nos escuchamos, nos vemos, eso para mí es muy importante, como que me tranquiliza. No es porque esté preocupada por mi familia, mis hijas viven con mi mamá y su papá también se hace cargo de ellas, no solo económicamente, de verdad está pendiente de sus hijas, más ahora que estoy lejos, pues va a verlas todos los días. Cuando venía planeando el viaje, les contaba todo a ellas y a mi ex marido, por eso se pusieron a ver las telenovelas, siempre me apoyaron, a veces yo quería que me dijeran "No te vayas Karla, quédate”, sobre todo lo esperaba de mi mamá, pero al contrario, ella me decía "Si quieres una vida mejor, tienes que irte un tiempo, si quieres estudiar todo eso que dices, tienes que buscarlo en otra parte, si quieres que tus hijas aprendan a valerse por sí mismas, debes enseñarles que se puede, será solo un tiempo y mientras estemos en contacto ambas partes estaremos tranquilas; ya que juntes tu dinerito entonces te regresas, o si encuentras algo bueno allá, entonces que tus hijas se vayan contigo, hasta yo". No es una típica mamá de las novelas mexicanas jajaja’.

Sabes que la vez pasada también me entrevistaron, justo cuando estaba montada en el tren, un director de cine Ultreras o algo así se apellida, estaba haciendo reportajes y yo salí en uno de esos, me decía "catracha, bájate del tren, vente conmigo, viaja con nosotros como si fueras parte del staff, será más seguro”, yo solo me reía y no me bajé, pero ahora creo que debería contactarlo, solo que no tengo sus datos. Uf me acuerdo que esa ocasión pensé, estos gringos no se dan cuenta de que la gente va a seguir cruzando, aunque los hayan deportado, aunque lo hagan con una pierna o sin un brazo'.

Curiosamente yo tengo el correo de Pedro Ultreras, precisamente porque ha hecho documentales acerca de la transmigración en México traté de contactarlo.

'Espero que tengas suerte con esta tesis, tanta picadura debe valer la pena, y mi mejor consejo para las mujeres que viajen, sería que sigan su intuición'. 


\subsubsection{Historia de Timothy}

Timothy $^{80}$, es un joven de Ghana, futbolista profesional, de 27 años (pero en su país dice tener 24 porque dentro del fútbol la edad importa mucho, más que la condición física), debido a ello pero sobre todo a conflictos religiosos se vio obligado a salir de su país, obteniendo una visa para jugar en un equipo de Colombia. No habla español por lo que en el albergue se me solicitó apoyo como traductora, razón por la cual conviví mucho tiempo con él y al acompañarlo a hacer varios trámites pude acercarme a otros espacios importantes en Tapachula para entender mejor el fenómeno migratorio.

'Bueno, no es nada fácil hablar de esto, el hablar duele pero el callar también. Yo vengo de una familia cristiana, soy el único varón, tengo tres hermanas, soy el menor, mi padre falleció, pero por el hecho de ser hombre tengo que hacerme cargo de toda la familia aun cuando soy el menor. He jugado fútbol desde que tengo memoria y me apasiona, gracias a Dios esa pasión me ha llevado lejos y jugando podía ganar buen dinero que en mi país no es tan fácil.... Solo que había un grupo de ancianos que querían convertirme al islam, más aún por la fama que yo estaba adquiriendo en el fútbol, pero yo no quería, si de algo estoy convencido es de mi religión; ellos insistieron mucho, hasta que quemaron una parte de mi casa, para demostrar su enojo por mi decisión. No sabes cómo sufrimos por eso, mi mamá me pidió que me alejara por nuestro bien, que me fuera a vivir a otro lugar en lo que se calmaban las cosas... no sabes lo duro que es que tu madre te pida que te vayas, espero que nunca lo experimentes; yo la entiendo y no quiero pensar en lo difícil que seguro está siendo para ella el que ahora estemos tan lejos el uno del otro. En el equipo me ayudaron mucho, tanto que me mandaron para un equipo de Colombia, uno de mis colegas me pagó el vuelo porque como te digo, mi salario se iba completo para la casa.

Siendo la primera vez que salgo de Ghana, la verdad es que siento desconfianza de la gente, de todo, venía con muchas ganas para jugar en el equipo colombiano, conocer América, wow es tan lejos de África, es tan diferente, ni siquiera podía imaginarme como era la gente, las casas, las costumbres, eso sí, vi varios vídeos de los estadios, de los equipos, para aprender cómo juegan aquí, en qué tipo de césped, etc. cosas técnicas del deporte, pero todo se dio

\footnotetext{
${ }^{80}$ He decidido dejar la traducción al español del relato de Timothy para hacer más ligera la lectura.
} 
tan rápido que no tuve tiempo de investigar mucho del país, por eso no estaba enterado de lo peligroso que es. Después de un viaje tan largo, tan agotador, llegué de madrugada, sin saber una palabra de español no sabía ni como saludar al taxista. Él se dio cuenta de lo nervioso que estaba, mientras me llevaba al hotel, me veía mucho, me bajó una calle antes y de repente dos hombres se acercaron y me pidieron que les diera todo lo que llevaba, Dios, juro que nunca había sentido tanta impotencia, porque llevaban pistolas y yo no, les di mi equipaje y me quedé con una pequeña bolsa, la que traigo, con algunas cosas de higiene, pero se llevaron mi cartera, jhasta mi pasaporte!, no sabía qué hacer, no tenía dinero, como identificarme en el hotel, nada, el taxista huyó, me quedé en medio de la nada sin saber qué hacer, por fortuna unos chicos se acercaron a mí y me preguntaron que me había sucedido, podía ver que eran africanos, eran migrantes de Somalia y Burundi y ellos me apoyaron mucho, me dieron algo de comer, algo de dinero y me dijeron que si iba a la policía solo perdería mi tiempo, porque al final no harían mucho por mí, ellos planeaban ir a Estados Unidos, así que me invitaron a ir con ellos, yo no quería estar más en Colombia, así que acepté, me sentí tranquilo con ellos, era como estar en mi patria. Por medio de buses distintos, pequeñas lanchas y a pie es como hemos hecho el viaje hasta acá, pero ellos no querían detenerse mucho tiempo aquí, yo ya estaba muy agotado y en Tecún Umán me hablaron de este albergue, por eso estoy aquí.

'Me dijeron que en México se vive bien, tengo muchas ganas de aprender el español y de practicar fútbol aquí, hay tanta gente que intenta venir o ir a los Estados Unidos, me impresionó mucho. Jóvenes, ancianos, mujeres, niños, familias enteras, jamás vi algo así. Me daba un poco de pena ver como algunas mujeres viajaban con sus bebés en brazos, es un camino duro... O ver personas que se notaban de verdad enfermas o viejas, no entendía porque lo hacían, porque arriesgarse tanto. Hablé con muy poca gente, es una gran limitante no hablar el idioma de jtodo un continente!, pero con los pocos que me entendían en inglés me sentí bien, me parece que la gente es cariñosa, pero también puede ser muy violenta.... Vi un par de veces que a las mujeres las tocaban, los mismos migrantes, yo no sabía qué hacer, si decir algo aunque fuera en inglés o no, una ocasión quise detener a un hombre que “acariciaba” a una chica, evidentemente ella no estaba a gusto, cuando me acerqué el hombre se puso furioso y quería pegarme, ella me hizo una señal en silencio para que no hiciera 
nada; vi que los demás veían lo que estaba pasando pero no hacían nada, era como si viajáramos ciegos/as, sordos/as y mudos/as, rarísimo'.

'No sabes qué alivio sentí al verme en la puerta del albergue. Aún con mis dudas de cómo sería el lugar, cómo me comunicaría y explicaría todo lo que me estaba pasando, sentía que este lugar era más seguro que muchos otros. Aquí me siento más tranquilo, pero hasta tener algún papel que me identifique, no quiero arriesgarme a salir del albergue’.

Fuimos a COMAR y ACNUR juntos, lo cual me dio una idea de cómo se solicita el refugio en México, notando varias diferencias en cuanto a las aprobaciones de acuerdo a la nacionalidad. En su caso, ACNUR le brindó dinero en efectivo, el acceso a las clases de español gratis y el pago del alquiler por tres meses, todo ello después de dos exhaustivas entrevistas. En COMAR nos comentaron que en casos así, de personas que vienen de países tan lejanos, el apoyo es otorgado de manera mucho más rápida. No es así con la gente solicitante de refugio de Centroamérica.

'He llamado a casa últimamente para contarles que estoy acá, de los cambios de planes con respecto a Colombia y para saber cómo van las cosas allá, todavía hay mucha tensión en el ambiente, será bueno no regresar en mucho tiempo’.

'Ahora que tengo un cuarto, comenzaré mis clases de español y practicaré fútbol con el equipo local, me siento en paz, gracias por todo. Dios es el mejor aliado en momentos difíciles, si hay algo que quiero que diga tu tesis es que la gente debe confiar en Dios, en cualquier viaje, proyecto, momento, él no te abandonará, ese es el mejor consejo que le daría a toda la gente en su búsqueda al "sueño americano o mexicano", no perder la fe y andar con cuidado. Mis amigos me cuentan sus historias, sabes cuántas veces Fredi ha cruzado o intentado hacerlo hacia Estados Unidos, 47 veces jte imaginas! muchas de ellas si lo ha logrado, viajando así, de manera ilegal, yo lo admiro mucho, en todos estos intentos lo han asaltado solo tres veces pero sin hacerle daño, esa es la muestra de su fe, jves como Dios acompaña a la gente migrante!'. 


\subsubsection{Trama de Kenia}

Kenia, es una de las personas de quien aprendí muchísimo, es toda una líder, el tiempo que convivimos me percaté de que mucha gente se acercaba a ella, fue gracias a esto que se dieron varias de las conversaciones grupales. Es una joven hondureña, de 19 años, viaja con su novio y pocos días antes de conocernos se enteró de que está embarazada, razón por la cual modificó algunos de sus planes.

'Yo considero primordial viajar y conocer otras cosas con tus propios ojos, disfrutar de la comida que tanto muestran en la tele, en las novelas, yo no conocía el mar, así que ahorré para hacerlo, pero quería que fuera en un viaje especial, siendo joven y sana puedes aprovechar para hacer las cosas que quieres, para eso tienes que prepararte y ahorrar, por eso yo trabajé mucho en un casino, al salir de clases allá hacía mis tareas, como pasaba tantas horas en el casino me daba tiempo, me apuraba a limpiar todo y mi jefe como era muy comprensivo me dịo que también podía tomarme tiempo para mí, mientras todo estuviera listo; tenía un catre y ahí dormía un ratito, es que me iba siempre de madrugada a las 2 o 3 de la mañana dependiendo de los clientes y mis clases empezaban a las 8, así que dormía bien poquito, pero bueno en el casino me organizaba bien y cuando empezaban a llegar los clientes, pues a trabajar. Me contrataron primero solo para hacer la limpieza, pero luego me pusieron de cajera y hasta ayudaba en cosas administrativas, el jefe vio que soy de confiar y buena con los números, así que me daba más responsabilidades y me subió el salario, por eso pude ahorrar más rápido. Luego se necesitaba un vigilante, entonces recomendé a René (su novio), era mejor para mí porque así pasábamos más tiempo juntos, aunque el jefe primero dijo que no quería nada de noviecitos, entonces le mentimos, le dije que era mi vecino, luego ya se dio cuenta, pero como hacíamos bien nuestro trabajo pues nos dejó quedarnos a los dos, por eso él también se puso a ahorrar'.

'Mi tío pagaba la escuela, no tuvo hijos y si dinero porque es gerente de un banco. Me ofreció sacar la visa para venir a México y para ir a los Estados pero es un trámite complicado y largo, piden muchos papeles, que compruebes muchas cosas y eso tarda, así que decidí venir por mi cuenta, pensé, total si me deportan no tengo nada que perder y al menos algo habría visto. Mi idea era pasar un tiempo en Guatemala, recorriendo todo lo que se pudiera, pasamos un mes ahí, viajando con calma, paseando, ¡Qué bonito país! y luego 
venir a México, porque mi deseo más grande era ver la basílica de Guadalupe y Puebla, porque me dijeron que era muy bonita la ciudad y que hay una iglesia de oro, ¿Es verdad?’

Le comenté que si existe una capilla chapada de oro, llamada "Capilla del Rosario" y le mostré algunas fotos.

'Luego pensé, bueno a lo mejor podemos ir hasta los Estados ya que estábamos acá, René también tenía ganas de conocer allá, solo que en el viaje me enteré de que estoy embarazada, así que bueno no puedo arriesgarme tanto ahora, por eso decidimos volver a Honduras. Pero bueno en el camino, ya veníamos con otra chica salvadoreña y con Kevin (joven salvadoreño de 16 años), unos policías nos robaron pero cómo identificamos unas placas, pues metimos la denuncia y por eso tenemos que estar en Tapachula, para esperar a que se resuelva el caso; además como René se dio cuenta que se puede trabajar y se gana mejor acá, pues decidimos quedarnos un tiempo, trabajar y llevar algo de dinero para cuando nazca el bebé. Mi trabajo lo tengo seguro en mí país, dejé a alguien en mi lugar como interina, pero pues ya sabes cuando ya tienes un bebé pues los gastos son mayores, por eso si podemos aprovechar y ahorrar algo, bienvenido sea'.

'San Pedro, es un pueblo bien bonito, hay muchos árboles frutales, la comida es rica, la gente es muy amable, bueno aunque hay de todo, pero en general la gente es muy hospitalaria, no es tan grande como Tegucigalpa y no hay todo lo que en la capital, pero se está más tranquilo, hay escuelas, bares, discotecas, casinos, parques; a mí la verdad me gusta mucho y aunque ahora he visto lugares bien preciosos, pues no me imagino viviendo en otro lugar que no sea mi pueblo. Allá está mi familia, tenemos una casa, trabajo, amigas, la escuela, ahí es donde quiero que crezca mi bebé... la verdad no planeábamos embarazarnos ahora, pero tampoco reniego de que haya pasado, nos cuidamos siempre pero bueno a veces falla, mi mamá dice que esas cosas no se pueden planear, cuando te va a llegar pues te llega. René está muy contento y es un hombre responsable, así que sé que será un buen padre, ya llevamos mucho tiempo juntos, nos hicimos novios cuando tenía 12 años y él 13, es mucho

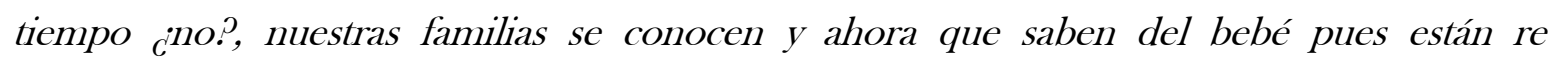
contentas,

'Yo quería seguir estudiando, una maestría o algo así, pero en otra escuela no con las monjas, en Honduras hay escuelas públicas y privadas, pero las públicas no son buenas la verdad, 
todo mundo lo sabe. Yo desde chiquita estudié con las monjas y pues después de tanto tiempo te cansas, son más estrictas pero te enseñan inglés, computación y cosas que en otros lugares no o solo así de pasadita. Pero bueno estudiar es importante, sea donde sea que lo hagas, por eso le digo a Kevin que estudié, que sirve en la vida, que está joven y puede aprovechar, no sé cómo sea en El Salvador, pero ir a la escuela a mí me parece muy importante. Por cierto, ¿ Y'Y te contó Kevin cómo nos conocimos. ${ }^{\text {' }}$

Mi respuesta fue negativa, así que ella me contó la historia. 'Conocí a Kevin porque su hermana me contactó en Facebook, a ella tampoco la conozco pero es una amiga de una amiga que sabía de mis planes para venir a México, entonces su hermana me preguntó si era posible que Kevin, su hermanito, viajará con nosotros, ella vive en los Estados y su intención es que se encuentren allá, platicamos mucho y me cayó muy bien, así que nos dimos algunos datos y acordamos un punto para encontrarnos con Kevin y viajar juntos un tiempo y luego él seguiría su paso hasta el norte; en el camino nos encontramos a otro catracho, a una salvadoreña, quien después del asalto mejor se regresó a su país, y a un costarricense. Ahora por mi embarazo yo me regresaré, él seguirá su camino con el otro catracho y el costarricense, ya le dije a su hermana que se ven de fiar, espero que así sea’.

'En este camino te puedes encontrar de todo, por eso hay que buscar gente buena de verdad, antes de venir estuve hablando mucho con gente que había ido a los Estados o que tienen familiares allá, un montón de hondureños están ahí o aquí en México; bueno mucha gente me dio varias ideas para preparar el viaje, René también investigó cosas y así nos preparamos. Entre ellas nos enteramos de que en Guatemala no hay problema para andar sin papeles y la verdad nunca nos sentimos inseguros. Pero entrar a México, ahí está la cosa, debes pagar al lanchero que te va a cruzar por el río, lo que te pida, muchas veces si ve que eres migrante te cobra el doble, pero si regateas, te peleas o no le pagas, llama a la migra. Supimos que hay varios albergues en el camino donde puedes quedarte, te dan ropa y te apoyan en casos de sufrir extorsión o algo así, justo por eso estamos aquí, ya nos han dejado quedarnos más del tiempo establecido que son tres días, pero porque estamos en este caso de denuncia, la verdad junto con Derechos Humanos nos han apoyado bastante. También 
está el grupo Beta ${ }^{81}$ que ayuda, nos explicaron que aunque estés como ilegal tienes derechos en México, otra cosa importante que nos dijeron es que lo más peligroso en este viaje es hacerlo en el tren, a ése si yo no me trepo, conozco a un señor que se cayó y perdió una pierna, su hijo se quedó sin un brazo, ¡Te imaginas, qué horror! A René lo estaban convenciendo para contratar un coyote, pero a los dos nos dio desconfianza, sobretodo porque no venimos en el mismo plan que mucha gente, venimos por ver algo nuevo pero no por necesidad, eso cambia mucho las cosas; puedo entender que la gente haga cosas desesperadas por huir o para sacar más dinero en otro país, pero no es nuestro caso, así que decidimos no arriesgarnos con un coyote. Mejor buscamos por internet como es la ruta, a donde hay que ir, que debes llevar, esas cosas’.

'Pues leímos que debíamos traer medicina para el dolor, porque se camina mucho bajo el sol, también que hay que andar con una mochila ligera, sin mucha ropa y zapatos cómodos, gorras para el sol y el dinero repartido en varias partes de tu ropa y tu cuerpo. Ya en el primer albergue al que llegamos en Tecún Umán, un viejito me aconsejó vestirme como hombre, me dijo "niña para que no te expongas vístete como hombre, ustedes las mujeres sufren más, simplemente por tener el cuerpo que tienen, he intentado el viaje muchas veces y es el mejor consejo que te puedo dar". Así que le hice caso, ahora uso gorra, pantalones flojos, playeras flojas, las de René y como no tengo tanto pecho se disimula bien, me amarro bien el pelo para que no se me vea y no hablo para nada; esto lo hago cuando debemos rodear el monte, y como lo hemos hecho de noche pues se nota menos mi cara. Aunque también puede servir en todos lados no solo en el monte, en los albergues también porque ahí también te vigilan, más si viajas sola, he escuchado decir "pues si viajan solas es porque buscan el peligro, y si van de vestido es porque están dispuestas a todo”. En el albergue de Arriaga sí que me dio miedo la verdad, el ambiente era muy feo, parecía como que estábamos rodeados de delincuentes, no sé cómo explicarlo, allá la puerta está siempre cerrada, no como aquí que puede entrar y salir cualquier gente, que también eso es peligroso, pero allá la atmosfera era muy rara. No hablé con nadie, incluso con René muy poco para que no escucharan mi voz, no fui exactamente como hombre, porque pues cuando te asignan habitación, tenía que ir con las mujeres, pero si estuve como cubriéndome

\footnotetext{
${ }^{81}$ El Grupo Beta es un organismo del Instituto Nacional de Migración, creado hace más de dos décadas para proteger y defender los derechos de las personas transmigrantes en México, con independencia de su nacionalidad o situación migratoria; su presencia es más constante en las vías férreas.
} 
la cara, cuidándome mucho ahí, no estaba como estoy vestida ahorita, ni hablaba con la gente como aquí, este lugar si me hace sentir bien. Ya René me dijo que aquí estoy hablando mucho, pero me fijo bien con quien, pero él es muy desconfiado?

Cosa que pude comprobar puesto que al hablar con Kenia y escribir, él me observó con cautela y me confesó que planeaba quitarme el diario de campo porque temía que la información que escribía fuera usada en su contra; posteriormente Kenia y yo le explicamos el objetivo de la convivencia y se unió a muchas de las conversaciones, al inicio, eso sí, me pedía leer lo escrito cada cinco minutos y al final de su estancia, leyó tanto sus aportaciones como las de Kenia y Kevin con muchísimo detenimiento.

'Ahora te puedo contar lo que he observado y según yo puede ayudar a pasar México sin tantos problemas:

$\checkmark \quad$ Una cosa que sirve es crear redes en Facebook, así conoces a gente que ha hecho el viaje y te dan consejos.

$\checkmark$ Si te para la migra y te hacen preguntas como “ "estás nerviosa?" debes mirarle a los ojos y decirle que no directamente, aunque lo estés debes mostrar como que su pregunta es ilógica.

$\checkmark \quad$ Si viajas sola, la migra no se mete mucho contigo; en este caso aunque viajaba con mi novio le dije que siempre debíamos sentarnos separados y no hablar mucho en el trayecto. Sobre todo cuando te bajan a hacer las revisiones, es mejor acercarte a un mexicano/a que se vea muy del lugar.

$\checkmark \quad$ Nunca te sientes atrás en el autobús, siéntate adelante o en medio, se sabe que atrás se van migrantes que no quieren ser descubiertos'.

$\checkmark \quad$ Si eres mujer suéltate el pelo (así lo usan ustedes) y maquíllate, no lleves mochila, lleva bolsa.

$\checkmark$ Llévate una revista o un libro, no te duermas, más bien ve leyendo o que te vean leyendo, así no te paran bola (no te hacen caso).

$\checkmark$ Como se sabe que acá la gente es devota de la virgen de Guadalupe, pues yo me la traje en una cadena de oro, que llevo junto al dinero, siento que me ha protegido, por eso no nos pasó nada grave, además es algo que si pasas por la migra o la poli y te la ven puesta pues sospechan menos de que no eres de aquí. 
$\checkmark$ Es bueno ir a iglesias cuando no tienes a donde dormir, si no te dan nada, al menos te dejan quedarte adentro y pues ya duermes en un lugar seguro. Tu religión es algo que puedes o no mostrar, habrá gente a la que no le importe pero habrá gente que si, por eso, a donde fueres haz lo que vieres.

$\checkmark$ Otra sugerencia que daría a la gente es que si te vas a arriesgar a hacer este viaje, no debes quedarte sin nada en casa. Yo digo que es un viaje peligroso y no deberías vender todo porque pueden deportarte y ya no tendrías nada a tu regreso. Lo mejor es intentarlo pero precavidamente, sabiendo que puedes perder mucho en el intento, pero no todo, ya el hecho de saber que tienes algo al volver a tu casa por cualquier motivo te deja en paz. Además habla con tu familia de los posibles riesgos, al menos se prepararían un poco si algo te pasa.

$\checkmark$ Trabajar mientras viajas, si es que puedes asentarte un tiempo, así ganas dinero, aprendes algo nuevo y te ocupas. Pero bueno creo que es más fácil para los hombres, los agarran rápido para trabajar en la construcción pero a una no, yo me la he pasado caminando días, solicitando trabajo, „Parece que a las mexicanas no les gusta trabajar! Porque he visto varios anuncios en el centro de la ciudad, a mí no me aceptan porque me piden papeles o por lo menos dos cartas de recomendación de mexicanos y no conozco a nadie, pero los anuncios siguen y siguen ahí, en San Pedro ya hubieran volado esos trabajos...la gente allá es muy trabajadora’.

'En general me parece que la gente mexicana es muy simpática y religiosa, ya se veía en las novelas, que siempre se casan por la iglesia para que puedan vivir juntos, o en cualquier final siempre sale una iglesia. En Honduras no es tan así, no sé si me verían aquí como una "fácil" como dicen las villanas, porque viajo con René, tendremos un bebé y no planeamos casarnos jajaja. En cuanto a religión, allá hay como más variedad, yo soy católica pero toda mi familia, excepto mi mamá, son testigos de Jehová, entonces casi no nos visitan en la casa porque no quieren ver al cristo o las santas que tenemos como decoración. Pero aquí sí me parece que casi toda la gente es católica, por eso hablar de la fe ayuda, a ti como persona y para que los demás te apoyen si lo necesitas, es como si les tocarás en lo profundo’.

Kenia me tocó en lo más profundo. 


\subsection{Salida del terreno}

Salí unos días antes de lo previsto del albergue puesto que Flor María me dijo 'contigo estamos haciendo muchas excepciones, ni siquiera sé cuándo planeas irte, ya estás haciendo nido aquí, esto me sorprendió mucho puesto que con antelación hablamos del calendario de actividades. Unos días antes había sido el cumpleaños de Mónica, me invitaron al festejo en un espacio del albergue en el que nuca había estado y me sentí como parte del cuadro, en cambio, ese día me sentí como una desconocida. Le comenté a Carlos y me dijo que no debía sorprenderme, Flor María últimamente se olvida de muchas cosas y seguramente mi calendario, así como mi solicitud previa se le escapaba de la mente. Recordé las palabras de la profesora Ana Alcázar, en relación a las sorpresas o cambio de planes que hasta estar en terreno puedes descubrir.

Comenzar a decir a la gente que me iba me provocó un poco de tristeza.

Fui a la casa de Laura, Miguel Ángel y Guardaespaldas, transmigrantes con quienes conviví mucho y vivían ahora cerca del albergue. Conversamos y nos reímos mucho de las chinches, me confesaron que cuando terminaba su tiempo en el albergue y no les renovaban, algunos decían para darse ánimo que era mejor, así no tendrían que compartir animales.

En la fonda de Hilda recibí muchos abrazos de toda la familia. Timothy llegó a despedirse de mí, diciéndome 'Tú fuiste mi madre aquí, sé que es una gran responsabilidad pero eso sentí, hasta ahora tú eres para mí como mi madre mexicana'. Esto me hizo sentir extraña, porque como madre no me había visualizado.

Me despedí del personal de los albergues, así como de algunas personas de las instancias visitadas, en persona y vía telefónica.

Con una sensación de paz, profundo agradecimiento y el corazón contento me despedí de esta parte del viaje. 


\section{Capítulo 4. Contemplando lo vivido}

Feminist pedagogies of antiglobalization can tell alternate stories of difference, culture, power and agency. (Chandra Mohanty) ${ }^{82}$

En este capítulo me propongo hacer un análisis de como considero que el género atraviesa esta realidad transmigratoria desde lo compartido y plasmado en estas breves historias de vida, las cuales son muy iluminadoras.

Comenzando por las motivaciones. Schutz citado por Palmerín ${ }^{83}$ denomina los "motivos para” los cuales están vinculados por el propósito proyectado a futuro de la migración, en la necesidad económica y el deseo de acceder a una vida mejor y los "motivos porque" estrechamente vinculados con los antecedentes de la acción y los procesos subjetivos de significación; ambos están estrechamente relacionados. Es por ello que la perspectiva transnacional me parece muy útil para abordar esta categoría de análisis, ya que el explorar situaciones de vida desde el lugar de origen, cómo se perciben durante el tránsito y la imagen de la posible vida en el destino dan cuenta con mayor claridad de los significados que tienen estas motivaciones para emprender este proyecto migratorio; sobre todo en una época en la cual la movilidad y la fluidez es una característica de la modernidad que influye a toda la población, es decir, a aquellas personas que deciden moverse de lugar, a aquellas que se quedan y tienen que reestructurar sus dinámicas sociales y de quienes sin participar directamente en este proyecto, se ven influidas por estas prácticas.

Es evidente que la violencia estructural y la falta de acceso a oportunidades en los países centroamericanos están cobrando mucha fuerza y la poca respuesta por parte de las instancias que deberían actuar en favor de la sociedad es muy notoria. Por ello no es sorprendente que estas circunstancias estén llevando a la movilización de la población a otros espacios geográficos donde su mayor protección es su propia agencia. Pero también el conocer otras razones que motivan a esta acción nómade es muy importante, puesto que

\footnotetext{
82 'Las pedagogías feministas de antiglobalización pueden alternar historias de diferencia, cultura, poder y agencia. Mohanty, "Under Western Eyes," 524 [traducción mía].

${ }^{83}$ Alfred Schutz, "El problema de la realidad social: escritos I" (Argentina, Amorrortu Editores, 2003), citado por Diana Palmerín Velasco, "Un acercamiento fenomenológico a la experiencia de las mujeres migrantes," en Género y Migración I, Coords. Esperanza Tuñón Pablos y Martha Luz Rojas Wiesner (Chiapas: Colegio de la Frontera Sur, 2012), 676.
} 
justamente el considerar la diversidad en este proyecto enriquece la percepción del fenómeno migratorio contribuyendo con ello a romper estereotipos y a crear propuestas.

En el caso de Armando y Daylin el huir de la Mara Salvatrucha podría ser parte de los "motivos porque”, ya que parece una decisión basada en acciones que ponían en riesgo sus vidas, pero a su vez ese escape significa la búsqueda de una vida diferente, mejor.

La violencia extrema de dicho grupo criminal, el acceso y uso del poder por su parte en contra de diversas personas, pero sobre todo en contra de las mujeres, demuestra la grave situación que enfrentan los países centroamericanos y México.

El poder transfronterizo de este grupo, así como el de otros cárteles mexicanos se refleja en el hecho de que los secuestros a transmigrantes se dan con relevante frecuencia en las fronteras, con el objetivo de facilitar el tráfico de drogas, la trata de personas, entre otros actos delictivos; esto no es una novedad pero no por ello debe dejar de alarmar a la población, no por ello deben "normalizarse" estos acontecimientos o culpabilizar a las personas por hacer este viaje. Esta criminalización disimula el hecho de que el caldo de cultivo de las organizaciones de delincuentes que lucran con la migración está constituido por las legislaciones represivas del fenómeno migratorio, que hacen muy difícil llevar a cabo la migración documentada dando como resultado la falta o evasión en la discusión centrada en los cambios de políticas en las sociedades de acogida.

La percepción plasmada por parte de Armando en relación al hecho de que el pertenecer a la MS otorga cierto prestigio para "conquistar o enamorar" a las chicas, fue compartida por más personas, lo cual es un ejemplo del cómo se sigue perpetuando la imagen de la virilidad relacionada a la violencia, al acceso a las drogas y a las armas.

Daylin también lo plasma cuando menciona el rito de entrada a dicho grupo, así como la razón por la cual decidió escapar, al recibir la última paliza. Aunque también pone en tela de juicio dicha virilidad cuando menciona los actos sexuales a los que era sometida; además, el hecho de que el ser transexual sea discriminatorio en su país, pero ella se sintiera realmente aceptada y valorada en ese grupo demuestra la ambigüedad en los actos de la Mara, la ambigüedad en la sociedad; ya que tal como lo manifestó personal de OIM, COMAR y ACNUR, los motivos por escapar de la intolerancia a la homosexualidad y transexualismo en 
Honduras y El Salvador están incrementando las solicitudes de visas humanitarias en México.

El hecho de encontrar en la prostitución una escapatoria, libertad como plantea Daylin rompe también con el estigma de victimización o delito en esta actividad, en línea con las aportaciones de Dolores Juliano, considero que el ampliar la visión en torno al tema tiene un alcance político que debe propiciarse.

Por otro lado, huir por conflictos religiosos es una razón para migrar que se visibiliza con mayor frecuencia en los últimos tiempos, el caso de Timothy muestra también como ciertas discriminaciones, por no cumplir con la edad "ideal” para ciertas actividades, seguir una religión o no hablar un idioma puede llevar a casos de violencia y desesperación.

La religión como estructura de poder puede generar dominación, el hecho de que Timothy se resistiera a ella y no accediera a ser su modelo aprovechando su fama dentro de un deporte, como el fútbol, que tiene un gran protagonismo dentro de muchas sociedades, es una contestación, una subversión a normas que tratan de ser impuestas por ciertos grupos de poder. Esto a pesar de todos los cambios que involucra esta decisión, tanto en su vida como en la de su familia, que tendrá que establecer nuevas formas de convivencia al prescindir de cierta manera del "hombre de la casa", que tal como él comenta, representa entre otras cosas, el papel de proveedor.

Por otra parte, las nuevas motivaciones manifestadas por Timothy, relacionadas al aprender español y practicar fútbol en México podrían ser nombradas como "motivos para”, los cuales me parecen también como una estrategia, ya que el cambio de planes debido a un acto violento lo ha llevado a establecerse en territorio mexicano sin planearlo, pero ha encontrado en este cambio nuevos propósitos para habitar su nuevo viaje.

Ahora bien, las migraciones femeninas representan un desafío para el orden de género, porque rompen con el esquema tradicional de movilidad femenina limitada y en particular cuando éstas viajan solas, desestabilizando la imagen de mujeres dependientes, arrastradas por sus parejas o familiares y con pleno desconocimiento a la nueva vida o trayecto a enfrentar. 
Tanto Karla como Kenia representan ese desafío con claridad, podrían ser nombradas como "mujeres estructuralmente viajeras" en contraposición con la imagen de la "mujer accidentalmente viajera" ${ }^{\$ 4}$.

El acceso a una mejor vida por medio de oportunidades laborales y el acceso a mayor capacitación son los motivos que han llevado a Karla a este proyecto migratorio. Su historia y el hecho de que su madre haya sido la persona que la motivara a emprender este viaje, refleja lo que Morokvasic ${ }^{85}$ plantea cuando menciona que las mujeres pueden ser las promotoras de movimientos o, si ellas no se mueven, pueden llegar a influenciar los movimientos de los demás y también pueden verse afectadas de diferentes formas por dicha movilidad. Rompiendo con ello el estereotipo de "madres sobreprotectoras" promovido por medios de comunicación, particularmente las telenovelas mexicanas.

En cuanto a Kenia, la curiosidad la movió junto a su novio a ser transmigrante tal como ella lo dice, por el deseo de conocer nuevas cosas y no por necesidad, lo cual evidencia que no compartía las motivaciones “por qué” de muchas personas para salir de su país de origen. Su grande motivación por experimentar nuevas vivencias la llevaron además de cumplir con algunos de sus sueños, a aprender nuevas cosas y compartirlas en un contexto que pone a prueba muchos de los estereotipos de género.

La otra categoría de análisis es el riesgo, primero señalaré lo que en este trabajo es entendido como tal, de acuerdo a la propuesta de Mary Douglas señalada por García, quien menciona que 'no se puede tener definición única de riesgo, puesto que al ser el riesgo un producto conjunto de conocimiento y aceptación, depende de la percepción que de él se tenga. La percepción del riesgo es entonces un proceso social y en sí mismo una construcción cultural $^{86}$. Entonces para entender cómo las personas determinan qué es un riesgo es

\footnotetext{
${ }^{84}$ Se refiere a la ruptura de la percepción de la migración femenina como dependiente de la masculina, la cual se apoya del estereotipo muy consolidado del hombre mayoritariamente más móvil geográficamente y la mujer caracterizada por permanecer en el lugar de origen. Recordando que al pertenecer a sociedades patrilocales, el modelo tradicional de mujer es el de la mujer que abandona su hogar de origen para ir a vivir al lugar de su marido. Juliano, "Mujeres estructuralmente viajeras," 382.

${ }^{85}$ Mirjana Morokvasic, "Migración, género y empoderamiento." Puntos De Vista 9, (2007): 33.

${ }^{86}$ Virginia García Acosta, "El riesgo como construcción social y la construcción social de riesgos," Desacatos no. 19 (septiembre-diciembre 2005):15-16.
} 
importante acercarse a las sanciones, símbolos, normas y castigos como elementos simbólicos de dicha construcción, la cual puede funcionar de diferente manera en cada sociedad.

Armando constantemente hacía mención de que la situación a la que se enfrentaba ahora junto a su familia era la sanción por sus actos, era el pago, aunque excesivo, por haberse involucrado con la Mara Salvatrucha.

Fueron varios los riesgos nombrados por su parte, en los cuales el miedo era una constante compañía; entre los riesgos mencionados, el más importante sería el ser separado de sus hermanos, atribuyéndose el papel materno en este recorrido, contrastando con la imagen que anteriormente quería demostrar, dicho en sus palabras, la de un joven valiente que no le temía a nada. Además el miedo a ser descubierto por miembros de la MS18 o por personal de migración, hacía que durante el trayecto permaneciera cubierto, no solo físicamente; dejando ver como su actitud y puedo imaginar que sus gestos corporales también, habían sido modificados junto a sus prioridades, ya que antes su objetivo era conquistar a una chica, ahora su madre y su familia se presentaban como sus pensamientos más recurrentes. Pasar de ser el chico de poder, con acceso a las armas y drogas, al joven que tenía que cuidarse hasta de hablar, da cuenta de la maleabilidad de la identidad, de cómo privilegios anteriores se convertían en opresiones ahora.

Daylin por su parte, nos comenta que el racismo, el mal trato por parte del personal del INM o de sus propias paisanas/os por ser parte del colectivo LGBTQ $^{87}$, así como los engaños y/o abusos por parte de la gente que ofrece trabajo a transmigrantes en territorio mexicano, de taxistas como lo comenta Karla, de lancheros que pasan a la gente por el río Suchiate, o robos por parte de la policía como lo comparte Kenia, es lo que se puede considerar como riesgoso, lo cual puedo relacionar con la idea de Besserer ${ }^{88}$, quien menciona que resulta difícil distinguir entre víctimas y victimarios, entre quienes guardan el orden y quienes lo trastocan, quienes pueden ayudarles a protegerse y quienes podrían

\footnotetext{
${ }^{87}$ Lesbianas, Gais, Bisexuales, Transgénero y Queer.

${ }^{88}$ Besserer Alatorre, "Regímenes de sentimientos y la subversión del orden sentimental,” 71.
} 
abusar de ellas/os en este recorrido. Mostrando el uso de poder en beneficio de unos cuantos.

Aunado a esto, Daylin comparte que le parece que los riesgos se presentan para todas las personas, no solo al colectivo de mujeres o LGBTQ, por lo que los postulados de McIntosh $^{89}$ y Fineman ${ }^{90}$, en relación a que no tenemos una sola identidad, sino múltiples en donde el género, edad, raza, grupo étnico, entre otros, pueden beneficiarnos de algunos privilegios y llevarnos a opresiones en otros, iluminan esta idea.

Ya el nombre de "La Bestia" o "Tren de la Muerte" da una idea de los peligros que al viajar en ella se puede presentar. Karla firmemente mencionó que a pesar de ello, todas las personas tienen el derecho a ocuparlo, contestando a una representación hegemónica que presenta a la corporalidad masculina como la única que puede enfrentar dicho riesgo. Plasmando más bien que pequeños elementos, como una estaca, puede representar la frustración a dicho viaje.

Por su parte, Timothy muestra con mucha claridad lo que muchas mujeres enfrentan en este viaje y la falta de acción de la gente alrededor. El viajar como "ciegas/os, sordas/os y mudas/os” entiendo que puede ser una estrategia de protección para evitar abusos y represalias, pero a su vez ese silencio, esa “ceguera” perpetua actos de violencia.

Las vivencias en este trayecto son muy poco denunciadas por el miedo a la deportación; éstas ya han sido documentadas en algunas investigaciones como las que han llevado a cabo Chávez y Landa, llegando a la conclusión de que en el caso de las mujeres la revictimización que sufren es mayor porque se asume que saben que se están enfrentando a múltiples violencias y por ende las aceptan, esto se refleja también en lo compartido por Kenia en relación a los comentarios que se hacen del viaje de mujeres solas y que usan vestidos, dando por sentado que en estas decisiones hay algún grado de aprobación de las agresiones, sobretodo del tipo sexual.

\footnotetext{
${ }^{89}$ McIntosh, "Unpacking the knapsack of white privilege," 31-36.

${ }^{90}$ Martha Fineman, “The vulnerable subject,” Yale Journal of Law \& Feminism 20, no. 1 (2008): 8-40.
} 
Dichos autores lo mencionan así 'La fuerza del patriarcado utiliza a las mujeres como objeto y rehén en esta guerra por la ganancia a toda costa, sin embargo, las mujeres migrantes son capaces de hacer frente a las circunstancias más desfavorables con valentía y creatividad’91.

Kenia y Daylin hacen constar que los peligros se viven en diferentes espacios, en los "no lugares”, incluso en aquellos en los que la seguridad debería ser compartida, como es el caso de los albergues.

El tener una pizarra en la entrada del albergue "Belén" con fotos de enganchadores, hombres todos, me pareció muy revelador; en conversaciones con el personal de dicho albergue se hacía mención a que las mujeres también podían ser peligrosas pero de manera muy velada, por obligación haciendo uso de sus "atributos femeninos", lo cual también fue manifestado por más personas en relación a los motivos que llevaban a Benji a cometer las estafas; o bien, los escasos estudios en relación a las mujeres que participan en grupos delictivos como la Mara Salvatrucha, como en el ejemplo que Armando nombró al contarnos acerca de la "veterana”, la líder de ciertas actividades delictivas; todo ello hace eco con el planteamiento de Juliano ${ }^{92}$, en el cual menciona que la idea de delito está pensada para aplicarla solo a los hombres, vistos como autónomos y por consiguiente responsables de sus actos, mientras que las faltas cometidas por las mujeres tienden a verse siempre como inducidas por otros y son testimonio claro de su debilidad.

Por otro lado, tomando en cuenta la tercera y última categoría de análisis, es decir, las estrategias, quiero señalar la frase captada en la exposición fotográfica ambulante "Somos Migrantes" que me pareció brillante para este tema.

“Los pensamientos creativos llegan fácilmente a las mentes desesperadas que luchan por obtener una nueva vida"

\footnotetext{
91 Ana Chávez Galindo y Antonio Landa Guevara, "Migrantes en su paso por México," Centro Regional de Investigaciones Multidisciplinarias de la UNAM, (2011): 16.

92 Dolores Juliano, “Delito y pecado. La transgresión en femenino,” Política y Sociedad 46, no.1 y 2 (Enero 2009): 80.
} 
Las personas en movilidad en su afán por alcanzar diversas metas, crean, aprenden, comparten, prueban estrategias que les permita enfrentar los posibles riesgos del viaje; se reinventan, hacen suyos mecanismos necesarios para transitar por espacios desconocidos o por el hecho de ser conocidos, tienen que ser reapropiados.

Las personas nómades con quiénes conviví movilizaron recursos sociales y económicos, crearon redes sociales que les ayudarían a cumplir su meta, algunas pidieron ayuda, buscaron acompañantes, coyotes, otras decidieron viajar solas. Algunas de sus estrategias se muestran en este documento, revelando su gran capacidad de acción, creatividad y solidaridad. El compartirlas nos parece una respuesta a la falta de información, retomando la idea de Tuana $^{93}$ a la ignorancia no pasiva.

El tener una meta clara ya sea de manera individual o colectiva, como lo menciona Armando, además diaria; o bien, prepararse psicológicamente a modo personal y a la familia o gente involucrada, hablando de las posibles vivencias en este trayecto, riesgos y oportunidades, tal como lo cuentan Kenia y Karla resulta muy útil, así como seguir la intuición como bien recalca con firmeza esta última. Estas acciones representan una estrategia psicoe-mocional poderosa que brinda o mantiene la fuerza de la acción nómade, propiciando su resiliencia, entendida como la capacidad de una persona o grupo para adaptarse y/o hacer frente de una mejor manera a lo desconocido o a circunstancias traumáticas.

Por otro lado, el respaldo familiar y el contar con una red social que atraviese fronteras ha sido nombrado como algo muy importante antes y durante el viaje por parte de todas estas voces transmigrantes, para lo cual el uso de las tecnologías de información y comunicación (TIC's), como Facebook, Whatsapp o Skype representa una forma de creación y mantenimiento de dichos apoyos de manera transnacional, donde mecanismos como el género, clase, raza, edad y funcionalidad juegan un papel importante. Gouma, et. al, ${ }^{94}$ lo plasman en su investigación, vislumbrando como la experiencia migratoria influencia la manera en que las personas, específicamente las mujeres latinoamericanas están

\footnotetext{
${ }^{93}$ Tuana, "The Speculum of Ignorance," 3.

${ }^{94}$ Assimina Gouma, et.al. "Self-defence IT: Migrant Women and ICTs Strategies," European Society for Socially Embedded Technologies 29 (2014): 1-19.
} 
interactuando con estas tecnologías, siendo cada vez más frecuente ya que se convierten en una herramienta tanto para quienes están fuera como para quienes se quedan, transformándose en una plataforma potente que entrelaza redes.

La religión católica tiene un gran peso en la sociedad mexicana, el vincularla con el activismo social está representando uno de los grandes pilares de apoyo para las personas transmigrantes y para quienes colaboran con ellas.

Los preceptos de fe son sumamente poderosos en esta experiencia transmigratoria. Algunos rituales religiosos pueden ser vistos como parte de un sistema de opresión en contra de mujeres, homosexuales u otros grupos que no quepan dentro del imaginario "deseable" de dicha estructura de poder. Sin embargo, en este espacio tal como lo mencionan Aquino y Tamez $^{95}$ pueden servir sobre todo a las mujeres para tratar de disuadir a un agresor de cometer algún ataque ante los ojos de Dios y recibir un castigo divino o bien, como Kenia y Timothy demuestran, algunos ritos y símbolos de dicha religión están siendo resignificados para vivenciar este proyecto de manera tal, que favorezca su paso por territorio mexicano, como herramientas psicoe-mocionales, de seguridad y protección, que a su vez pueden potenciar la solidaridad entre la comunidad viajera y la receptora.

Como ya se ha dicho anteriormente, los objetos juegan un papel muy importante en el viaje transmigratorio, una literatura creciente sobre la cultura material desde la arqueología y antropología feminista ha demostrado la relevancia en el estudio de los mismos, los cuales han sido significativos en la formación y expresión de los saberes culturales, de las condiciones espaciales y de sus diversas manifestaciones en determinadas prácticas, siendo una buena manera de romper con ciertos estereotipos.

Boruchoff plantea que 'es importante tomar en cuenta que el mismo objeto puede tener distintos significados para individuos diferentes o para el mismo individuo en ocasiones diferentes $^{96}$, en este contexto las herramientas materiales, tales como medicina, calzado, ropa, artículos de higiene, documentos, entre otros (algunos al margen de la ley), fueron nombrados con la firme convicción de que podrían facilitar el trayecto para todas las

\footnotetext{
${ }^{95}$ María Aquino y Elsa Tamez, Teología feminista latinoamericana (Quito: AbyaYala, 1998).

${ }^{96}$ Boruchoff, "Equipaje cultural," 4.
} 
personas y por ello debían ser dadas a conocer, diferenciando solo pocos elementos en el uso que hombres o mujeres debían darles, por ejemplo al uso de mochilas y bolsas; con un claro reconocimiento en el hecho de que los objetos también pueden señalar el objetivo migratorio.

El tema de la infancia migrante ha sido una de las claves que abrió con fuerza la discusión en torno a la migración indocumentada en Estados Unidos. Es contemplado como una estrategia puesto que ha visibilizado el fenómeno migratorio fomentando solidaridad, pero también puede tener un efecto represor. Lo manifestado por Armando da cuenta de ello, al compartir la utilidad en el hecho de cambiarse de edad, tal como él lo dice, porque un número no representa la responsabilidad de una persona pero puede también separar a un grupo. El determinar hasta donde disponer de derechos y responsabilidades de la infancia y dar paso a otras obligaciones es un gran debate que sin duda debe considerar otros elementos contextualizados en un trayecto como éste; no ahondaré en ello puesto que es un tema en el cual no me he involucrado pero me parece importante nombrarlo.

En este recorrido algunas de las personas participantes, como Armando, Daylin, Karla y Kenia plantean que el hecho de inventarse, fingir, hacerse pasar por alguien del lugar al que van, son herramientas importantes a ocupar, tanto para enfrentarse o esconderse de “otras/os" que puedan suponer un peligro para el cumplimiento de su proyecto, para no ser consideradas como personas diferentes, invasoras/es, "ilegales" y, de esta forma hacer frente y manejar las fronteras de pertenencia y exclusión. Donde la heteronormatividad y patriarcado penaliza y excluye a identidades de género que se salen de la norma, considerándolas extrañas o extranjeras y que por lo tanto pueden ser rechazadas a través de mecanismos legales y/o simbólicos, o bien, asignadas a las periferias, es decir, lugares donde pueden favorecer a cierta sociedad pero sin recibir nada a cambio, donde pueden ser reconocidas pero marcando una distancia, en línea con aportes de Fanon ${ }^{97}$ donde los mismos grupos "periféricos" o "condenados de la tierra" pueden imitar y apropiarse de códigos de los grupos expulsores o colonizadores, porque depende de la relación entre cómo estás situada/o físicamente y como piensas, es decir puedes ocupar una posición subalterna y pensar como opresor, para sentirte como "afortunado/a de la tierra”.

\footnotetext{
${ }^{97}$ Frantz Fanon, Los condenados de la tierra, (México: Fondo de cultura económica, 1963).
} 
En palabras de Karla el reinventarte es además un escape gratificante, para el cual estudiar a la población a imitar se convierte en una tarea divertida, colectiva y temporal. Lo cual me parece que demuestra como esas relaciones asimétricas y dominantes pueden ser transformadas y resistidas, como el enfrentarse a la Otredad puede resignificarse. Esto sin dejar de problematizar la necesidad de inventarse máscaras de supervivencia, retomando a Bauman $^{98}$, para poder “pertenecer o integrarse” a cierta sociedad, cada vez más global, fluida y maleable.

El feminismo decolonial vislumbra dichos argumentos; desde la propuesta de Spivak ${ }^{99}$ retomo la alusión que hace acerca del poder y resistencia vistos como múltiples, a la importancia de destruir el lugar del subalterno pero también del opresor, porque el ocupar el lugar de bienestar para unos cuantos se da gracias a que una gran cantidad de personas se mantienen dentro de la subalternidad. En este recorrido me parece que ambos lugares son intercambiables, puesto que en ocasiones el poder puede ser ejercido por la sociedad mexicana frente a las y los transmigrantes pero también viceversa, siendo los grupos delictivos quienes mantienen el control buena parte del tiempo en una gran cantidad de espacios.

De las propuestas de Mohanty $^{100}$ tomo en consideración la importancia de fomentar una solidaridad feminista, en este caso transnacional, formulando acciones basadas en la autonomía, geografía, historia y contexto. Al acercarnos a las estrategias que ocupan las mujeres transmigrantes y los grupos subalternos en sus nuevas situaciones, dando cuenta de lo que resulta más gratificante, peligroso, etc. para comprender esta realidad social y dar luz a respuestas por medio de los feminismos, de pensamientos producidos desde los márgenes en diálogo con los conocimientos generados por intelectuales, activistas y personas comprometidas con desmantelar mecanismos de opresión múltiple. Por ejemplo, otra voz

\footnotetext{
${ }^{98}$ Zygmunt Bauman, Modernidad Líquida (México: Fondo de cultura económica, 2002).

${ }^{99}$ Gayatri Spivak, "¿Puede hablar el sujeto subalterno?” Trad. José Amícola." Orbis Tertius, 3, no. 6. (1998): 175-235. Consultado 18 de julio 2015. http://www.fuentesmemoria.fahce.unlp.edu.ar/art_revistas/pr.2732/p r.2732.pdf.

${ }^{100}$ Mohanty, "Under Western Eyes,” 499-535.
} 
migrante no mencionada en este texto, mencionó el uso de pastillas anticonceptivas para evitar embarazos en casos de violaciones sexuales como una buena estrategia, que si bien, demuestra que el cuerpo no es el límite, también da cuenta de cómo solo un grupo, las mujeres, tienen que desarrollar pensamientos creativos para evadir opresiones múltiples.

Otras estrategias o percepciones nombradas, siguen el orden de género tradicional pero para sus propios fines. Por ejemplo, Karla lo plasma en el hecho de que inventar un embarazo puede desviar ciertas miradas y con ello, riesgos o, el unirse a un hombre y viajar como “esposa” evita ser molestada. Las que Kenia comenta en relación al hecho de que oficiales de migración no se “meten” mucho con las mujeres, o bien, que el travestirse como hombre y no hablar, sea un estrategia para evitar más riesgos, puesto que la corporalidad femenina puede ser más atacada de acuerdo a la percepción del hombre que le dio estos consejos; este performance, este desdibujar características físicas en función del contexto, demuestra como para habitar el viaje se puede habitar un nuevo cuerpo, se puede construir socialmente, vislumbrando su agencia. Sin embargo, no es de menor relevancia que se tenga que evitar mostrar un cuerpo femenino, para no ser percibido por algunas personas como "territorio de conquista”.

Todo esto me lleva a considerar la propuesta de Segura y Zavella, citadas por Palmerín ${ }^{101}$, en relación a las "subjetividades transnacionales" que "remiten a las formas en que las mujeres (yo diría que no solamente a ellas) se adaptan a las transformaciones estructurales para refutar y/o crear representaciones de sus identidades a la luz de su marginalidad, y con esto dar voz a su capacidad de agencia. A la vez que reflejan la experiencia de sentirse en 'casa' que es más que una ubicación geográfica, donde la construcción identitaria es desterritorializada como parte de la cambiante mezcla en las fronteras; además es reterrritorializada según Palmerín ya que es una apropiación de un nuevo espacio (física o simbólicamente) dando otro significado a la experiencia migratoria, tanto para quienes la vivencian de manera directa como para quienes lo hacen de manera indirecta.

\footnotetext{
${ }^{101}$ Palmerín Velasco, "Entre el aquí y el allá," 3.
} 
Para concluir, considero que la apuesta de Espinosa Miñoso $^{102}$ por recuperar el espacio pequeño de la comunidad (en su sentido múltiple), en poner la mirada en los procesos locales que influyen a comunidades enteras, transfronterizas, ayudará a visibilizar lo que ha sido invisibilizado, a expresar la vulnerabilidad y resistencia mediante acciones interpelantes a las normas hegemónicas, a mostrar la agencia de las personas transmigrantes, de las y los nómades, de las mujeres.

${ }^{102}$ Yuderkis Espinosa Miñoso, "Una crítica descolonial a la epistemología feminista crítica," Revista El Cotidiano, (2014): 7-12. 


\section{Capítulo 5. Creando una nueva ruta}

"Una cosa es cierta, una parte de nosotros muere para reinventarse, porque las y los forasteros no hemos pagado nuestro boleto en vano" (Somos Migrantes)

La migración es un proceso vivo, histórico y actual, que se va adaptando según las estructuras de la sociedad de los países emisores, de tránsito y los receptores, es un proceso que va entrelazando vidas, historias, sueños; es también un fenómeno mediático a la orden del día. Se va transformando y es persistente por más barreras y muros que se intenten establecer, porque frente a estos se anteponen las mentes creativas de quienes van en busca de algo diferente en esta vida.

El trayecto transmigratorio me parece un andar a través de un camino conformado por diversas texturas, formas, colores, olores y un caleidoscopio de e-mociones que se van tejiendo, brindando tanto a las y los actores como a las y los espectadores paisajes en constante movimiento. Quien camina sobre ese tejido, desarrolla capacidades y fortalezas tal vez desconocidas, tal vez no, que se convierten en las compañeras de viaje, algunas veces junto a la incertidumbre y sorpresas latentes; sin duda el equipaje que no puede dejarse en casa es el deseo inmenso de alcanzar metas y transformar realidades.

Un Estado, un país, un colectivo o una persona no deberían enfrentar a solas violencias y desigualdades en diversas modalidades, las cuales se manifiestan con especial tonalidad en un trayecto como el abordado en este trabajo. Se necesitan muchos esfuerzos individuales y colectivos para dar respuesta a quienes están en busca de lo que otras sociedades ya tienen, de privilegios que ya gozan, que en su búsqueda de oportunidades encuentran en el movilizarse hacia los sueños mexicanos, americanos y europeos una posible vía de obtención.

Las fronteras se abren cada vez más para la circulación de objetos y tecnologías, muchas de los cuales han facilitado la vida, muchos de los cuales están al margen de la legalidad. Sin embargo, cuando se trata de personas (mientras no sea para su uso y abuso) es cada vez más notorio como las fronteras se intentan cerrar con firmeza, mediante muros físicos y simbólicos; muchas personas se convierten en un problema, en un peligro, en vecinas/os 
indeseables, pero a su vez en una fuente de ingresos (no solo en el sentido económico), en parte del sostén de las sociedades.

Por ello, la justicia debería ser ejercida para las personas en movilidad (aunque no solo para ellas), parece una tarea compleja por lo cual el encontrar, descubrir, redescubrir, manifestar y potenciar la propia resistencia y agencia se convierte en una respuesta de acción, en el apoyo a dicha tarea y, el feminismo en una gran oportunidad.

La academia feminista no se limita a la producción de conocimientos teóricos sino que también se involucra directamente en prácticas políticas y activistas en función de ideologías y luchas que favorezcan a la humanidad. Fomentando la capacidad de pensar, manifestarse y decidir, desvelando y resignificando el uso del poder, desde actos cotidianos, desde las palabras, desde discursos, representaciones, en fin, desde muchas formas que permitan el disfrute de una vida digna para todas las personas.

Me parece importante nombrar a las mujeres transmigrantes como protagonistas de este viaje, si bien, la colaboración no fue únicamente por parte de ellas y por eso he tratado de plasmar las voces de más personas con quienes me siento muy agradecida. Sin embargo, el reconocer los esfuerzos de quienes por mucho tiempo han sido invisibilizadas, silenciadas y discriminadas, hacerlo desde su propia voz, me parece una vía para mostrar su gran potencial, su gran fortaleza, sus múltiples capacidades, sus deseos y su confianza en un mundo mejor. Lo cual también es un llamado a la sociedad y a las estructuras de poder que tienen la función de protegerlas, como a otros grupos "minoritarios o periféricos" pero sin victimizarlas, haciendo notar parte de las dificultades por las que atraviesan o deben evitar, enfrentándose a acciones intolerables.

Este trabajo además de tener la intención de evidenciar lo que está sucediendo en dicha frontera, de dar a conocer de manera parcial la diversidad transmigratoria centroamericana en un trayecto, desde un intento por hacerlo bajo una mirada feminista, también propone brindar algunas propuestas para crear una nueva ruta de acción ante este fenómeno, algunas utópicas tal vez, para desarrollarse a largo plazo y otras más concretas. 
Cuando le pregunté a Flor María que podía hacer como retribución por el apoyo brindado en el albergue Belén me dijo 'Escribe lo que te cuentan, haz oración por nosotros y habla'. Esta es una de las formas en la que hablo.

La idea, la propuesta, la ilusión que se presentó recurrentemente en muchas voces transmigrantes, voces de quienes de diversas maneras acompañan este fenómeno y desde mi propia voz es, voltear la mirada a los países que están expulsando a más personas, los que están sufriendo violencias extremas, falta de oportunidades, injusticias en su máxima expresión, para enfocar esfuerzos y economías para reducir esas desigualdades latentes y propiciar mejoras. Pero también atender a las poblaciones que están consumiendo más drogas, más tráfico de personas, de mujeres, de esclavitud en sus diversas manifestaciones; muchas ocasiones divagamos al tratar de responder a ¿Por qué está siendo tan necesario y/o deseado ese consumismo?, ¿Qué es lo que está faltando o sobrando a las sociedades que pueden pagar por este tipo de actos?, ¿Por qué algunas personas, transmigrantes en este caso, son consideradas como objetos desechables?, ¿Por qué los cuerpos de las mujeres son vistos como territorios que pueden ser apropiados?, ¿Es necesario y posible alcanzar la felicidad para algunas personas por medio de estas prácticas?. No desciframos las respuestas, dejo planteadas estas interrogantes para continuar en la búsqueda de revelaciones.

Coincidiendo con Flor María, Laura, Ximena, Sofía, Paty, Psicólogo y Henri voces transmigrantes de Honduras y Salvador, que manifestaron como la mejor solución para que este viaje no sea vivenciado con tal crudeza, el hecho de hacer más fácil y menos costoso el trámite para la obtención de visas o permisos que permitan migrar de manera documentada, con períodos bien establecidos y nuevas reformas que beneficien tanto a la población receptora como a la de movilidad, tomando en cuenta los derechos de ambas partes como estandarte. Al viajar dentro de la legalidad no serían "presas" tan fáciles de capturar, los países destino tendrían un mayor control de quien accede a su territorio y los actos criminales podrían ser mayormente denunciados.

El insistir como lo están haciendo movimientos sociales en América Latina, académicas feministas y estudiantes, en la promoción de mejoras dentro de la política y la legislación mexicana en favor de la defensa de los derechos de las personas transmigrantes, es otra propuesta. 
Así como también, el capturar historias por medio de la narrativa, las buenas prácticas periodísticas, la fotografía y el cine, son proyectos muy potenciales que ya se llevan a cabo para dar a conocer, representar y reflejar en los ojos de las demás personas, vivencias, luchas, dificultades y reivindicaciones, claro está mientras no reproduzcan la cultura patriarcal. Karla, Chapín y Fredi transmigrantes de Honduras, Guatemala y Nicaragua quienes participaron en el rodaje de algunos documentales o de la película "La jaula de oro" nombraron estas prácticas como 'una cosa interesante porque así la gente se entera de lo que pasamos, es un poco duro verlo, pero es así... luego verte en la tele te hace sentir como alguien de bien calidad.

Sin duda, otra de las acciones que benefician y beneficiarían este trayecto, es fomentar la capacitación y sensibilización para todas las personas que interactúan en este fenómeno. Esto fue especialmente nombrado por Jaqueline Villafana de OIM, quien considera que al no recibir capacitación, desde el personal que recibe en las instancias migratorias a las y los transmigrantes, quienes hacen investigaciones judiciales y brindan veredictos de refugio, hasta de quienes generan las políticas públicas, no adecuándose a las nuevas tendencias migratorias, está generando discriminaciones, especialmente hacia la población LGBTQ. Además menciona que la falta de coordinación de esfuerzos por parte de las instancias, al menos en Tapachula, está generando una repetición de acciones. Por ello propone la creación de un programa regional para el fortalecimiento de redes que abordan el tema desde diversas ópticas. Esta propuesta me parece muy interesante, la cual podría ampliarse a otros niveles, a otros lugares, ya que al ser un fenómeno transnacional se requiere de un conjunto muy amplio de esfuerzos.

Considero también importante el hacer conciencia a la población acerca de la gran labor que los albergues están realizando, fomentando el apoyo a los mismos desde el acompañamiento psicológico al personal (el cual no reciben) hasta la generación de recursos, pero sin restarles autonomía.

Uno de mis compromisos como lo mencioné previamente, es dar a conocer las estrategias compartidas con las personas que emprendan el viaje, de manera tal que sirva como una herramienta más para el mismo; es por ello que crearé un folleto fácil de llevar con esta 
información. Dicha propuesta ya ha sido aceptada por los albergues visitados para su distribución, aun siendo considerada de alguna manera transgresora.

Me parecía que en este texto quedaría fuera mucho de todo lo vivenciado, por fortuna, casualidad o causalidad una de mis amigas, Sonia, quien es escritora y viajera, me propuso hacer el intento de escribir una especie de recopilatorio de historias transmigrantes para dar a conocer en otras esferas esta experiencia, lo cual puede ser una forma más de hablar y seguiré en busca de otras.

Por último, quiero resaltar que es posible que una mujer lleve a cabo investigaciones en espacios de violencia, se ha hecho desde hace mucho tiempo. Enfatizo este punto como respuesta a un comentario por parte de un académico experto en la frontera sur, quien puso en tela de juicio mi decisión de realizar este trabajo en dicha frontera por el hecho de ser mujer, joven e inexperta, porque al formar parte de la "burbuja feminista" estaba exenta de objetividad, lo cual daría como resultado un trabajo poco académico, sin novedad y sin aceptación dentro del gremio investigador. Pues bien, mi falta de experiencia, tiempo en campo y miedos fueron algunas de las limitaciones en este trabajo, que sin duda tendré que mejorar para futuras investigaciones, pero a pesar de ello me siento contenta con los resultados.

También tengo claro que este tipo de documento tal vez no será bien recibido en algunas esferas académicas pero mi apuesta es continuar en esta línea, en la "burbuja feminista”, la cual considero como uno de los espacios más poderosos y transformadores para una vida más justa y, desde aquí, seguir reinventándome como las y los forasteros en su proyecto migratorio, continuando en otros viajes en pos del derrumbe de muros y creación de puentes. 


\section{Guías de viaje (Bibliografía)}

\section{Libros y artículos}

Abu-Lughod, Lila. "Locating Ethnography." SAGE Publications 1, no. 2 (2000): 261-267.

— "Honor and the Sentiments of Loss in a Bedouin Society." American Ethnologist 12, no. 2 (May 1985): 245-261.

Acevedo, Mariela Hemilse. "Aportes de la teoría social de Alfred Schutz para pensar la política y la acción colectiva." Trabajo y Sociedad no. 17 (2011): 83-94.

Acosta García, Virginia. "El riesgo como construcción social y la construcción social de riesgos." Desacatos. Revista De Antropología Social no. 19 (2014): 11-24.

Agazzi, Elena y Vita Fortunati. Memoria e Saperi. Percorsi transdisciplinari. Roma: Meltemi editore, 2007.

Alberston Fineman, Martha. "The Vulnerable Subject: Anchoring Equality in the Human Condition." Yale Journal of Law \& Feminism 20, no. 1 (2008): 8-40.

Amnesty International. Víctimas invisibles: Migrantes en movimiento en México. Amnistía Internacional, 2010.

Angelyn Mitchell. Within the Circle: An Anthology of African American Literary Criticism from the Harlem Renaissance to the Present. USA: Duke University Press, 1994.

Anzaldua, Gloria. Bordelands/La Frontera. San Francisco: Aunt Lute, 1987.

Aquino, María Pilar y Elsa Tamez. Teología feminista latinoamericana. Quito: Abya Yala, 1998.

Arendt, Hannah. Eichmann en Jerusalén. Barcelona: Lumen, 2013.

Arendt, Hannah y Manuel Cruz. La condición humana. Barcelona: Paidós, 1993.

Atencia Escalante, Javier. "Antropología y emociones: Geertz y Taylor." Thémata: Revista de Filosofía, no. 35 (2005): 451-456.

Aviña Zavala, Camila. "Desarrollo humano y migración. Dos caminos que se encuentran." Bien Común 13, no. 154 (2007): 35-37.

Bankoff, Greg, Georg Frerks, y Dorothea Hilhorst. Mapping Vulnerability: Disasters, Development, and People. London y NY: Routledge, 2004.

Bastia, Tanja. "La feminización de la migración transnacional y su potencial emancipatorio." Papeles de relaciones ecosociales y cambio global. no.104 (2009): 67-77.

Bauman, Zygmunt. Modernidad Líquida. México: Fondo de cultura económica, 2002. 
—. Vidas desperdiciadas. La modernidad y sus parias. Buenos Aires: Ediciones Paidós, 2006.

Behar, Ruth. Translated Woman: Crossing the Border with Esperanza's Story. Boston: Beacon Press, 1993.

. The Vulnerable Observer: Anthropology that Breaks Your Heart. Boston: Beacon Press, 1997.

Behar, Ruth y Deborah A. Gordon. Women Writing Culture. Berkeley: UC Press, 1995.

Besserer Alatorre, Federico. "Estudios transnacionales y ciudadanía transnacional." Fronteras fragmentadas (1999): 215-238.

."Regímenes de sentimientos y la subversión del orden sentimental. Hacia una economía política de los afectos." Nueva Antropología 27, no. 81 (2014): 55-76.

Boruchoff, Judith. "Equipaje cultural: Objetos, identidad y transnacionalismo en Guerrero y Chicago." Fronteras fragmentadas (1999): 499-518.

Boyce-Davies, Carole. Black Women, Writing and Identity: Migrations of the Subject. London y NY: Routledge, 2002.

Braidotti, Rosi, Amalia Fischer Pfeiffer, Gabriela Ventureira, y Maria Luisa Femenias. Feminismo, Diferencia Sexual y Subjetividad Nómade. Barcelona: Gedisa, 2004.

Briones Gamboa, Fernando. "La complejidad del riesgo: breve análisis transversal." Revista de la universidad Cristóbal Colón. no. 20: 1-12. Consultado 15 marzo de 2015. www.eumed.net/rev/rucc/20/.

Butler, Judith. Violencia de Estado, guerra, resistencia. Por una nueva política de la izquierda. Traducido por Patrícia Soley-Beltran. Madrid: Katz Editores, 2011.

- Bodies that Matter: On the Discursive Limits of Sex. UK: Taylor \& Francis, 2011.

Caamaño Morúa, Carmen. "Entre 'Arriba' y 'Abajo'. La experiencia transnacional de la migración de Costarricenses hacia Estados Unidos." San José: Editorial UCR, 2010.

Castillas, Raúl. "Las rutas de los centroamericanos por México, un ejercicio de caracterización, actores principales y complejidades." Migración y Desarrollo, no. 10 (2008): 157-174.

Castro Soto, Oscar. Mujeres Transmigrantes. México: Centro de Estudios Sociales y Culturales, Antonio Montesinos, A. C., 2010.

Chávez Galindo, Ana María y Antonio Landa Guevara. "Migrantes en su paso por México: Nuevas problemáticas, rutas, estrategias y redes." 3er. Coloquio de migración internacional. Las migraciones regionales y extra-regionales en, hacia y desde Latinoamérica y el Caribe. Entre el mito y la realidad, pronunciado en Chiapas, 2011. 
Claramunt, María Cecilia. Mujeres Maltratadas: Guía de trabajo para la intervención en crisis. OPS, 1999.

Cruz Salazar, Tania. "Racismo cultural y representaciones de inmigrantes centroamericanas en Chiapas." Migraciones Internacionales 6, no. 2 (2011): 133-157.

Decreto de la Frontera Sur. DOF: 08/07/2014. Consultado por última vez: 04/07/2015. http://observatoriocolef.org/_admin/documentos/DRECRETO\%20FROTERA\%20SUR.pdf.

De León, Jason. "Better to be Hot than Caught: Excavating the Conflicting Roles of Migrant Material Culture." American Anthropologist 114, no. 3 (2012): 477-495.

Del Olmo, Margarita. Dilemas éticos en antropología: Las entretelas del trabajo de campo etnogŕafico. Madrid: Trotta, 2010.

Del Valle Murga, Teresa. "Un ensayo metodológico sobre la mirada en la antropología social." Gazeta de Antropología 28, no. 3 (2012).

Domínguez Villanueva, María Isabel. "Género y Migración: Estrategias de mujeres migrantes centroamericanas en tránsito por México." En Género y Migración I, coordinado por Esperanza Tuñon Pablos y Martha Rojas Wiesner, 93-116. México: El Colegio de la Frontera Sur, 2012.

Douglas, Mary. La aceptabilidad del riesgo según las ciencias sociales. Barcelona: Paidós, 1996.

Draga Alexandru, Maria Sabina, Madalina Nicolaescu y Helen Smith. Between History and Personal Narrative. Viena: LIT Verlag Münster, 2013.

Echeburúa, Enrique y P. Corral. "Intervención en crisis en víctimas de sucesos traumáticos: ¿Cuándo, Cómo y Para Qué?” Psicología Conductual 15, no. 3 (2007): 373-387.

Egenhoff, Tjark y Eduardo Stein. Seguridad y crimen organizado transnacional: Una propuesta de acción para Centroamérica. Guatemala: Fundación Konrad Adenauer Stiftung, 2011.

Espinosa Miñoso, Yuderkys. "Una crítica descolonial a la epistemología feminista crítica." Revista El Cotidiano (2014): 7-12.

"A una década de la performatividad: De presunciones erróneas y malos entendidos." Otras Miradas (2003): 27-44.

- "Etnocentrismo y colonialidad en los feminismos latinoamericanos: Complicidades y consolidación de las hegemonías feministas en el espacio transnacional." Revista venezolana de estudios de la mujer 14, no. 33 (2009): 37-54.

Esquivel, Laura. Como agua para chocolate. México: Grijalbo, 1989.

. El libro de las emociones: Son de la razón sin corazón. México: Plaza \& Janés, 2000. 
Esteban, Mari Luz. "Antropología encarnada. Antropología desde una misma." Papeles del CEIC. International Journal on Collective Identity Research, no. 12 (2004): 1-21.

_. "El estudio de la salud y el género: Las ventajas de un enfoque antropológico y feminista." Salud Colectiva 2, no. 1 (2006): 9-20.

Fanon Frantz. Los condenados de la tierra. México: Fondo de cultura económica, 1963.

Fernández Montes, Matilde. "Sujetos como objeto de estudio" En dilemas éticos en antropología: Las entretelas del trabajo de campo etnográfico, Editado por Margarita del Olmo, 303-314. Madrid: Trotta, 2010.

Foucault, Michael. Vigilar y Castigar. Argentina: siglo veintiuno, 2002.

Fricker, Miranda. "On Miranda Fricker's Epistemic Injustice: Power and the Ethics of Knowing." Revista de teoría, historia y fundamentos de la ciencia 23, no. 1 (2008): 69-71.

Galeano, Eduardo. Mujeres. México: siglo veintiuno editores, 2015

García, María del Rosario. Mujeres afectadas por el fenómeno migratorio en México. Una aproximación desde la perspectiva de género. México: INMUJERES, 2007.

Gregorio Gil, Carmen. "Contribuciones feministas a problemas epistemológicos de la disciplina antropológica: Representación y relaciones de poder." AIBR: Revista de antropología Iberoamericana 1, no. 1 (2006): 22-39.

- "La categoría género a la luz del parentesco en el análisis de las migraciones transnacionales." Anuario Americanista Europeo 11 (2013): 11-29.

. .Mujeres inmigrantes: Colonizando sus cuerpos mediante fronteras procreativas, étnicoculturales, sexuales y reproductivas." Viento Sur: Por una izquierda alternativa 18, no. 104 (2009): 42-54.

—_. "Tensiones conceptuales en la relación entre género y migraciones. Reflexiones desde la etnografía y la crítica feminista." Papers 97, no.3 (2012): 569-590.

- "Traspasando las fronteras dentro-fuera: Reflexiones desde una etnografía feminista," AIBR, Revista de antropología Iberoamericana 9, no. 3 (2014): 297-321.

Gregorio Gil, Carmen y Martha Patricia Castañeda Salgado. Mujeres y Hombres en el mundo global. Antropología feminista en América Latina y España. México: Siglo XXI Editores, 2012.

Gregorio Gil, Carmen y Ana Alcázar Campos. "Trabajo de campo en contextos racializados y sexualizados. Cuando la decolonialidad se inscribe en nuestros cuerpos." Gazeta de antropología 30, no. 3 (2014): 1-16.

Gouma, Assimina, Waltraud Ernst, Kim Carrington y Luzenir Caixeta. "Self-Defence IT: Migrant Women and ICT's Strategies." European Society for Socially Embedded Technologies, (2014): $1-9$. 
Haraway, Donna. "Situated Knowledges: The Science Question in Feminism and the Privilege of Partial Perspective”. Feminist Studies 14, no. 3. (Autumn, 1988): 575-599.

Harding, Sandra. "Is There a Feminist Method?” En Feminism and Science, editado por Nancy Tuana (Bloomington/Indianapolis: Indiana University Press, 1987), 18-32.

Howland, Samantha Elizabeth. "Migra y Maras: The Relationship between the Proliferation of Central American Street Gangs and Migratory Patterns in the Northern Triangle, Mexico, and the United States." Tesis fin de máster. Universidad de Georgertown, 2014. https://repository.library.georgetown.edu/handle/10822/709745.

Hernández García, Jone. "La autoetnografía como habitáculo. Espacios para vivir y compartir". Seminario organizado en el marco del proyecto "Etnografiando prácticas de Resistencia. Escenarios, eventos y narrativas en la construcción de la ciudadanía," en el 2012.

Hernández, Franklin Gil. "Racismo, homofobia y sexismo. Reflexiones teóricas y políticas sobre interseccionalidad." En Raza, etnicidad y sexualidades. Ciudadanía y multiculturalismo en América Latina, editado por Peter Wade, Fernando Urrea Giraldo y Mara Viveros Vigoya, 485-512. Bogotá: CES, 2008.

Hochschild, Arlie Russell. "The Nanny Chain." American Prospect 11, no. 4 (2000): 32-36.

Hooks, Bell, Avtar Brah, Chela Sandoval, Gloria Anzaldúa, Aurora Levins Morales, Kum-Kum Bhavnani, Margaret Coulson, M. Jacqui Alexander y Chandra Talpade Mohanty. Otras Inapropiables: Feminismos desde las fronteras. Madrid: Traficantes de sueños, 2004.

Jolly, Susie. Gender and Cultural Change. Bridge: Institute of Development Studies, 2002.

Joysmith, Claira. "Ya se me quitó la vergüenza y la cobardía. Una plática con Gloria Anzaldúa," en Fronteras y cruces: Cartografía de escenarios culturales latinoamericanos, coordinado por María Belausteguigoitia y Martha Leñero, 215. México: Universidad Nacional Autónoma de México, 2006.

Juliano, Dolores. "Delito y pecado. La transgresión en femenino." Política y Sociedad 46, no. 1 (2009): 79-95.

-."El cuerpo fluido. Una visión desde la antropología." Quaderns de Psicologia. International Journal of Psychology 12, no. 2 (2010): 149-160.

."Género y trayectorias migratorias en época de crisis." Papers 97, no.3 (2012): 523-540.

"Mujeres estructuralmente viajeras: Estereotipos y estrategias (Entrevista)." Papers 60 (2000): 381-389.

Larraitz Lexartza, Artza, Ana Carcedo Cabañas y María José Chaves Groh. Mujeres Centroamericanas en las migraciones. México: PCS/CEFEMINA, 2012.

Lázaro Castellanos, Rosa y Olga Jubany- Baucells. "Mujeres de origen inmigrante: Cuerpos y subjetividades en movimiento." Ra Ximhai 8, no. 1 (2012): 169-180. 
Maisterra Sierra, Olivia Alejandra. "Experiencias transmigratorias de mujeres centroamericanas: Viajeras invisibles, un caleidoscopio de emociones." Escritores en formación, (2012): 77-97.

Marrujo Ruiz, Olivia. "Los riesgos de cruzar. La migración centroamericana en la frontera MéxicoGuatemala." Frontera Norte 13, no. 25 (2001): 1-22.

Martínez Pizarro, Jorge. El mapa migratorio de América Latina y el Caribe, las mujeres y el género. CEPAL- Serie Población y Desarrollo, 2003.

McIntosh, Peggy. "Unpacking the Knapsack of White Privilege." Independent School 49, no. 2 (1990): 31-36.

Mohanty, Chandra Talpade. "Bajo los ojos de occidente. Academia feminista y discurso colonial." En Descolonizando el feminismo: Teorías y prácticas desde los márgenes, editado por Liliana Suárez Navaz y Aída Hernández, 112-161. Madrid: Cátedra, 2008.

."Under Western Eyes. Revisited: Feminist Solidarity through Anticapitalist Struggles." Signs 28, no. 2 (2003): 499-535.

Molina Bastante, Elisabet. "Género y resiliencia en la gestión integral del riesgo de desastres." Tesis fin de grado. Universidad de Castilla- La Mancha, 2014. https://ruidera.uclm.es/xmlui/bitstream/handle/10578/3916/TFG_\%20Molina\%20Bastante.pdf ?sequence $=3$.

Montiel Torres, Oscar. Trata de personas: Padrotes, iniciación y modus operandi. México: INMUJERES, 2009.

Monzón, Ana Silvia. Las viajeras invisibles: Mujeres migrantes en la región Centroamericana y el sur de México. Guatemala: PCS-CAMEX, 2006.

Moraga, Cherríe y Gloria Anzaldúa. This Bridge Called My Back: Writings by Radical Women of Color. NY: Kitchen Table, Women of Color Press, 1983

Moraga, Cherríe y Ana Castillo. Esta Puente, Mi Espalda: Voces de mujeres tercermundistas en los Estados Unidos. San Franciso: Ism Press, Inc. 1988.

Morett Sánchez, Jorge. "Migrantes centroamericanas en tránsito por México: Un caso extremo de violencia de género." Conferencia pronunciada en el seminario internacional Fazendo Genero, Florianópolis, 2013.

Morokvasic, Mirjana. "Birds of Passage are also Women." International Migration Review (1984): 886-907.

"Migración, género y empoderamiento." Puntos De Vista 9, (2007): 33-49. 
Negro, Virginia. "Comunicar el viaje. La representación de la experiencia transmigratoria de las mujeres en la prensa escrita mexicana." Tesis fin de máster. Universidad de Lodz/Granada, 2014.

http://digibug.ugr.es/bitstream/10481/33996/6/TFM.\%20Comunicar\%20el\%20viaje.\%20Mast er\%20GEMMA.\%20Virginia\%20Negro.\%20Final.pdf.

Palacios Zarco, David. "Sobre el uso y el abuso de la migración femenina centroamericana. Estado de la cuestión." Cuadernos Geográficos 41, (2007): 263-281.

Palmerín Velasco, Diana. "Cruce de fronteras y género: Subordinación, transgresión y liberación en el circuito migratorio de Axochiapan a Minneapolis." Anuario Americanista Europeo 11, (2013): 109-126.

—. "Entre el aquí y el allá: subjetividades transnacionales de género en el circuito migratorio Axochiapan-Minneapolis". Tesis doctoral. FLACSO México, 2011. http://repositorio.flacsoandes.edu.ec/bitstream/10469/3338/1/TFLACSO-2011DGPV.pdf.

."Reconstruyendo y renegociando la identidad en el exilio: El caso de refugiados latinoamericanos en Londres, Inglaterra." (2014): 1-19.

Pérez Orozco, Amaia y Denise Paiewonsky. Cruzando Fronteras. Migración y desarrollo desde una perspectiva de género. República Dominicana: UN-INSTRAW, 2008.

Phoenix, Ann y Pamela Pattynama. "Intersectionality." European Journal of Women's Studies 13, no. 3 (2006): 187-192.

Red de Documentación de las Organizaciones Defensoras de Migrantes. "Narrativas de la transmigración centroamericana en su paso por México. Informe sobre las violaciones a derechos humanos y delitos cometidos a transmigrantes centroamericanos." México: SJM, 2013.

Rich, Adrienne. "Notes Toward a Politics of Location." En Feminist Postcolonial Theory: A Reader, editado por Reina Lewis y Sara Mills, 29-42. NY: Edinburgh University Press, 2003.

Rigoni, Flor María. El norte se vuelve sur. México: A.M.A.C, 2010.

Rivera Heredia, María Elena, Nydia Obregón Velasco y Ericka Ivonne Cervantes Pacheco. "Recursos psicológicos y salud: Consideraciones para la intervención con los migrantes y sus familias." Aportaciones de la Psicología a la Salud (2009): 225-254.

Roca i Girona, Jordi, Yolanda Bodoque Puerta y Montserrrat Soronellas Masdeu. "Migraciones por amor: Diversidad y complejidad de las migraciones de mujeres." Dialnet 3, no. 97 (2012): 685-707.

Rojas Wiesner, Martha Luz. "Mujeres y migración en la frontera sur de México," Amérique Latine Histoire et Mémoire. Les Cahiers ALHIM 14 (agosto, 2008), consultado 8 de febrero de 2015. https://alhim.revues.org/2252?lang=fr

Rossini, Carlos e Isabel Vericat Núñez. Bajo el Tacaná: La otra frontera: México/Guatemala. México: Sin Nombre, 2007. 
Rostagnol, Susana. "Trabajo de campo en entornos diversos. Reflexiones sobre las estrategias de conocimiento." Gazeta de Antropología 27, no. 1 (2011): 1-12.

Santiago Cruz, María de Jesús. "Migración y transmigración en la frontera sur de México. Reflexiones sobre su relación e impacto en el desarrollo local." Memorias de la XII reunión de economía mundial" Caminos para superar la crisis global, pronunciada en 2010.

Sassen, Saskia. Contrageografías de la globalización. Género y ciudadanía en los circuitos transfronterizos. Madrid: Traficantes de sueños, 2003.

Scheper-Hughes, Nancy. "Ire in Ireland." Ethnography 1, no. 1 (2000): 117-140.

Shiva, Vandana. "Abrazar la vida: Mujer, ecología y desarrollo." Madrid: Horas y Horas, 1995.

Snider, Leslie, Mark Van Ommeren y Alison Schafer. Psychological First Aid: Guide for Field Workers. Geneva: World Health Organization, 2011.

Spivak, Gayatri Chakravorty. "¿Puede hablar el sujeto subalterno?” Traducido por José Amícola." Orbis Tertius, 3, no. 6. (1998): 175-235. Consultado 18 de julio de 2015. http://www.fuentesmemoria.fahce.unlp.edu.ar/art_revistas/pr.2732/p r.2732.pdf.

Stanford Friedman, Susan. "Locational Feminism: Gender, Cultural Geographies, and Geopolitical Literacy" En Feminist Locations: Local and Global, Theory and Practice, editado por Marianne Dekoven, 13-36. USA: Rutgers University Press, 2001.

Tuana, Nancy. "The Speculum of Ignorance: The Women's Health Movement and Epistemologies of Ignorance." Hypatia 21, no. 3 (2006): 1-19.

Tuñón Pablos, Esperanza y Martha Rojas Wiesner. Género y Migración Vol. I, México: El Colegio de la Frontera Sur, 2012.

Velasco Díaz, Andrés. "De la política de lo mental a la experiencia corporal." Lúdica Pedagógica 2, no. 16 (2011): 123-134.

Walker, Alice. "In Search of our Mothers' Gardens." En Within the circle: an Anthology of African American literary criticism from the Harlem Renaissance to the present, editado por Angelyn Mitchell, 401-409. Durham and London: Duke University Press, 1994.

Williams, Justin L. "Gendered Racism and the Moderating Influence of Racial Identity: Implications for African American Women's Well- being." Tesis fin de grado. Georgia State University, 2015. http://scholarworks.gsu.edu/psych_diss/136. 


\section{Materiales audiovisuales}

Alarcón, Daniel. "En El Salvador, las pandillas amenazan hasta los más pequeños actos de expresión personal." Radio ambulante. Artículo posteado el 21 de agosto del 2015. http://radioambulante.org/audio/postal-de-san-salvador.

El tren de la muerte. Reportaje de Stefan Rocker. Televisión alemana SWR y Phoenix, 2012.

La jaula de oro. IMDb. Dirigida por Diego Quemada-Díez. México: Animal de Luz Films, Kinemascope Films y Machete Producciones, 2013.

La vida precoz y breve de Sabina Rivas. IMDb. Dirigida por Luis Mandoki. España y México: Churchill Toledo, CONACULTA y FIDECINE, 2012.

Pérez, Lolany, Jennifer Ávila y Camila Segura. "El coyote.” Radio ambulante. Artículo posteado el 29 de julio del 2015. http://radioambulante.org/audio/el-coyote.

Somos Migrantes. Exposición fotográfica itinerante. Promovida por Entreculturas. España, 2015.

7 Soles. IMDb. Dirigida por Pedro Ultreras. México: Cuadrante films, 2008. 


\section{Anexo I. Guías para la recopilación de información.}

\section{a) Guía para explorar las experiencias de las mujeres:}

\section{Presentación de mi persona y de mi objetivo:}

Hola, buenos días (tardes, noches). Soy Margarita Trejo Velasco, chiapaneca y estudiante de una maestría en estudios de género y de las mujeres. Me acerco a ti porque estoy realizando una tesis que consiste en abordar el tema de la transmigración en esta ciudad, con el objetivo de mostrar la diversidad de vivencias en este trayecto. Me interesa hablar de este tema porque yo he sido migrante también y me parece que es muy importante mostrar que las múltiples experiencias que se viven en este tipo de viaje. Este trabajo será producto de muchas colaboraciones, entre ellas la tuya si te interesa participar; a mí me gustaría aportar otra mirada a su movilidad, dando cuenta de sus capacidades de acción y decisión, sin embargo, el resultado del mismo dependerá de lo que ustedes quieran compartir. En principio este trabajo será leído por quienes forman parte de la academia española que valorará este trabajo, algunas amistades y familiares, pero también podrá ser leída por otras personas en función de lo que al final queramos mostrar y de las personas a quienes decidamos mostrarles este trabajo.

Mi intención es convivir contigo y con otras personas que se encuentren en el albergue y quieran participar en este proyecto. Durante esta convivencia haré varias preguntas en función de una guía que he elaborado, pero es una herramienta abierta, es decir, que podemos agregar, modificar o evadir preguntas. Trataré de plasmar también lo observado y lo que experimento en este proceso y te mostraría lo escrito de tu participación. La idea es que ambas aprendamos, compartamos ideas, momentos, experiencias con respeto y sinceridad, que nos llevemos algo grato de este encuentro y en la medida de lo posible logremos crear algo que haga de este viaje mejor vivible. ¿Qué opinas?

\section{Negociaciones:}

Considero que es importante establecer algunos acuerdos.

Para comenzar, puedes decidir si quieres decirme tu nombre real y si quieres que se plasme así con tu testimonio, o si bien, prefieres crear un nombre ficticio. Esto aplica también para la gente que menciones, en caso de ser así.

Traigo conmigo una grabadora de voz, una cámara fotográfica, una libreta y la guía que te mencione previamente. Puedes decidir si quieres que nuestras conversaciones sean grabadas, en caso de que no, haría uso de mi libreta para hacer anotaciones. También puedes decirme si te gustaría ser fotografiada, ya sea sola, con otras personas o conmigo. Y si quieres que alguna de esas fotos aparezca en el documento.

La idea es mostrarte lo que escriba de tu participación para que me digas si estás de acuerdo o no con mis interpretaciones y juntas plasmemos tu aportación por escrito.

Si quieres leer el trabajo final, podemos acordar la forma de envío, ya sea una copia en papel por correo postal o bien en formato electrónico.

Podemos platicar acá o buscar otro espacio donde ambas nos sintamos cómodas. Si en algún momento ambas queremos parar, hablar de otra cosa, tomar un 'respiro' a solas o no nos sentimos a gusto, podemos decirlo con confianza.

¿Estás de acuerdo con esto?, ¿Hay algún otro acuerdo que te gustaría que tomáramos? 


\section{Guía:}

¿Cuál es tu nombre o cómo quieres que te diga (recordando la negociación previa)?

¿Cuántos años tienes?

¿Cuánto tiempo llevas en el albergue y cuánto más planeas quedarte?

¿Cuál es y cómo es tu país de origen?

¿Cuál es y cómo es la ciudad o lugar de dónde provienes?

¿Qué te gusta de (Nombre del país)?

¿Qué no te gusta de ese lugar?

¿Qué te gusta de tu ciudad o comunidad?

¿Qué no te gusta de ese lugar?

¿Cuáles crees que sean las causas de esas situaciones?

¿Qué crees que debería cambiar para mejorar la situación en dicho lugar?

¿Qué idiomas se hablan ahí?

¿Qué idiomas hablas tú?

¿A qué te dedicabas allá?

¿Qué actividades te gustan hacer?

¿Cuáles hacías allá y con quien(es)?

¿Podrías describirme como era el lugar donde vivías?

¿Con quién o quiénes vivías en dicho lugar?

En función de la respuesta ahondar en:

¿Cómo te llevas con (familiares, pareja o hijos/as)?

¿Cuántos hijos/as tienes?, ¿Qué edad o edades tienen? ¿Cómo son?

¿Se quedará(n) en tu ciudad?

¿Quién se hará cargo de tus actividades o familiares (en caso de ser responsable del cuidado de alguien) mientras no estás?

¿Qué acuerdos se establecieron para ello?

¿Planeas enviar dinero?

¿Cómo? y ¿Quién lo recibiría?

¿Por qué decidiste salir de tu ciudad?

¿Por qué decidiste salir de tu país?

¿Desde cuándo lo decidiste?

¿Cuánto tiempo te llevo tomar esa decisión? 
¿Lo decidiste sola o con familiares/amistades?

¿Cómo les explicaste la decisión tomada?

¿Estuvieron de acuerdo con tu decisión de migrar?

¿Qué crees que opinan de tu decisión en tu comunidad?

¿Conoces a alguien más que se haya ido de tu lugar de origen por las mismas u otras circunstancias?

¿Sabes cómo hicieron el viaje?

¿Mantienes contacto con esa(s) personas? De ser así ¿Cómo?

¿A qué lugar decidiste ir?

¿Por qué?

¿Cómo te imaginas que es ese lugar?

¿Cómo te gustaría que fuera tu vida allá?

¿Por cuánto tiempo te gustaría quedarte?

¿Hay familiares o personas que conozcas en el lugar de destino?

De ser así, ¿Has establecido contacto con ellos/ellas?

¿Te apoyarán de alguna manera?

¿Dónde vivirás?

¿Con quién(es)?

¿Conoces algún lugar en el que podrías trabajar?

¿Sabes cómo se llevan a cabo los contratos laborales o las condiciones en las cuales podrías trabajar?

¿Planeas regresar a (nombre de la ciudad, dependiendo de la información previa)?

¿Es la primera vez que haces este viaje?

En caso de no ser así:

¿Qué ha ocurrido en intentos previos?

¿Por qué decidiste intentarlo nuevamente?

¿Qué cambios has contemplado esta vez para llegar a la meta?

¿Cómo planeaste el viaje?

¿Obtuviste información acerca de los países o lugares por los cuales tienes que atravesar?

De ser así, ¿Cómo?

¿Qué sabes de dichos lugares?

¿Cómo imaginaste que sería este viaje?

¿Está siendo como lo pensabas? 
¿Qué riesgos o retos crees que se puedan presentar?

¿Cómo piensas afrontarlos en caso de que se presenten?

Hasta el momento ¿Se ha presentado alguno de esos riesgos u otros?

De ser así ¿De qué tipo y por parte de quien(es)?

¿Qué has hecho para enfrentarlos?

¿Cómo obtuviste los recursos económicos y materiales para hacer el viaje?

¿Cuál es la ruta que piensas seguir?

¿Cómo la definiste?

¿Qué medios de transporte piensas ocupar?

¿Qué medios has usado hasta ahora?

¿Cuentas con alguien que te apoye o acompañe durante el trayecto?

¿Piensas contratar a un coyote o pollero?, de ser así ¿Cómo piensas contactarlo? O bien, si ya tienes el contacto, ¿Cómo han negociado su apoyo?

¿Qué cosas consideras importante llevar contigo durante el viaje?

¿Por qué?

¿Planeas mantener el contacto con tus familiares o amistades mientras viajas a tu destino, de ser así, cómo?

¿Cómo mantendrán la comunicación una vez que llegues a tu meta?

¿Cómo te preparaste para el viaje física y emocionalmente?

¿Cómo te has sentido desde que tomaste la decisión de viajar?

¿Qué estrategias has ocupado para enfrentar, mantener o intensificar esos sentimientos?

¿Cuáles has creado para afrontar el desapego de tu familia/pareja/amistades/lugar de origen?

¿Qué crees que podría darte fuerza durante el viaje?

¿Qué crees que podría darte tranquilidad en el trayecto?

¿Qué elementos externos crees que podrían ayudar a dicho propósito?

Ahora bien, ¿Cuáles son las cosas que crees que podrían afectar tu tranquilidad o ánimo en el viaje?

¿Cómo crees que podrías afrontarlos?

¿Podrías describirme cómo ha sido el trayecto desde que saliste de tu casa hasta ahora?

¿Qué extrañas de tu lugar de origen?

¿Cuál ha sido el momento más difícil?

¿Cuál ha sido el momento más fácil?

¿Cómo ha sido la convivencia con las otras personas en el camino? 
¿Qué es lo que más te ha gustado de los lugares por los cuales has pasado?

¿Qué es lo que menos te ha gustado?

¿Cómo crees ahora que continuará el viaje?

¿Has pensado en hacer algunos cambios en los planes?, ¿Por qué?

¿Cuáles serían?

¿Cómo te parecen las personas de los países o lugares por los cuales has pasado?

¿Cómo te han tratado?

¿Percibes diferencias entre las mujeres de los distintos países centroamericanos con quienes has viajado?

¿Has notado alguna diferencia en cómo son tratadas?

¿Qué opinas de la gente mexicana?

¿Cómo ha sido el trato que has recibido en Tapachula?

¿Cómo te gustaría ser tratada mientras viajas?

¿Cómo crees que la gente de acá te ve o percibe?

¿Cómo te gustaría que te vieran?

¿Cómo supiste de la existencia de este albergue?

¿Cómo te has sentido aquí?

¿Crees que podría mejorar en algún aspecto? De ser así ¿En cuál y cómo?

Con tu experiencia ¿Qué recomendarías a las mujeres que decidan hacer este trayecto?

¿Hay algo en concreto que te gustaría que esta tesis aporte? 


\section{b) Guía para explorar las experiencias de las personas involucradas en instancias}

Presentación de mi persona, mi objetivo y negociaciones, tal como lo describí antes.

\section{Guía:}

¿Qué servicios les ofrecen en esta institución?

¿Cómo lo hacen?

¿Qué dificultades encuentras en esa labor?

¿Cuáles crees que sean las causas para que se dé la movilización de las personas de su lugar de origen?

$¿$ Crees que hay alguna diferencia en la vivencia del viaje entre diversos grupos como hombres, mujeres o población LGBT?

O bien, por nacionalidad y edad ¿Crees que hay diferencias en cómo se perciben y cómo son tratadas las personas que vienen de diferentes países de Centroamérica de acuerdo a su edad?

De ser así ¿Cuál o cuáles? y ¿Por qué?

¿Sabes cómo llevan a cabo el trayecto las personas?

En caso afirmativo ¿Cómo obtuviste dicha información?

¿Cuál crees que sea el mayor reto en esta frontera para hacer frente a este fenómeno?

¿Cómo crees que se podría dar respuesta?

¿Qué opinión se plasma acerca de la transmigración en esta institución?

Específicamente ¿en relación con las mujeres transmigrantes?

Con tu experiencia ¿Qué recomendarías a las mujeres que decidan hacer este trayecto?

¿Hay algo en concreto que te gustaría que esta tesis aporte? 


\section{Anexo II. Mis propias estrategias para habitar el viaje}

* El vivir en el albergue permitió que la gente sintiera confianza conmigo y yo me sentí segura.

* Explicar la razón de mi estancia y releer sus aportaciones (aunque no siempre fue posible).

* Hablar de política, recetas de cocina, medicinales, festejos nacionales o familiares, leyendas, eventos de nuestras vidas, nuestros miedos, ilusiones, etc. Así como llevar crucigramas, sopa de letras y/o adivinanzas, ya que ayudaba para iniciar la conversación, detenerla por algún motivo o a modo de despedida.

* Aprender palabras que se usan en Centroamérica.

* Asistir a misas.

* Grabar mi propia voz en momentos de prisa o cansancio.

* Múltiples ocasiones recibí propuestas matrimoniales, las cuales evadí diciendo que estaba casada, al inicio me sentí mal por no ser honesta pero resultó lo más apto en esas circunstancias.

* Descifré algunas retribuciones que podía aportar para quienes me apoyaron en este trabajo:

- Donar ropa, zapatos o artículos de higiene.

- Sacar dinero de Western Union que se les enviaba

- Prestar mi teléfono para hacer o recibir llamadas

- Dar dinero para pagar pasajes o medicinas

- Ser testigo para el trámite del visado de Henri, joven hondureño

- Acompañar en diversas instancias migratorias y consulados

- $\quad$ Ofrecer este trabajo para su entrega virtual 


\section{Anexo III. Mapas}

\section{Mapa 1. Chiapas}

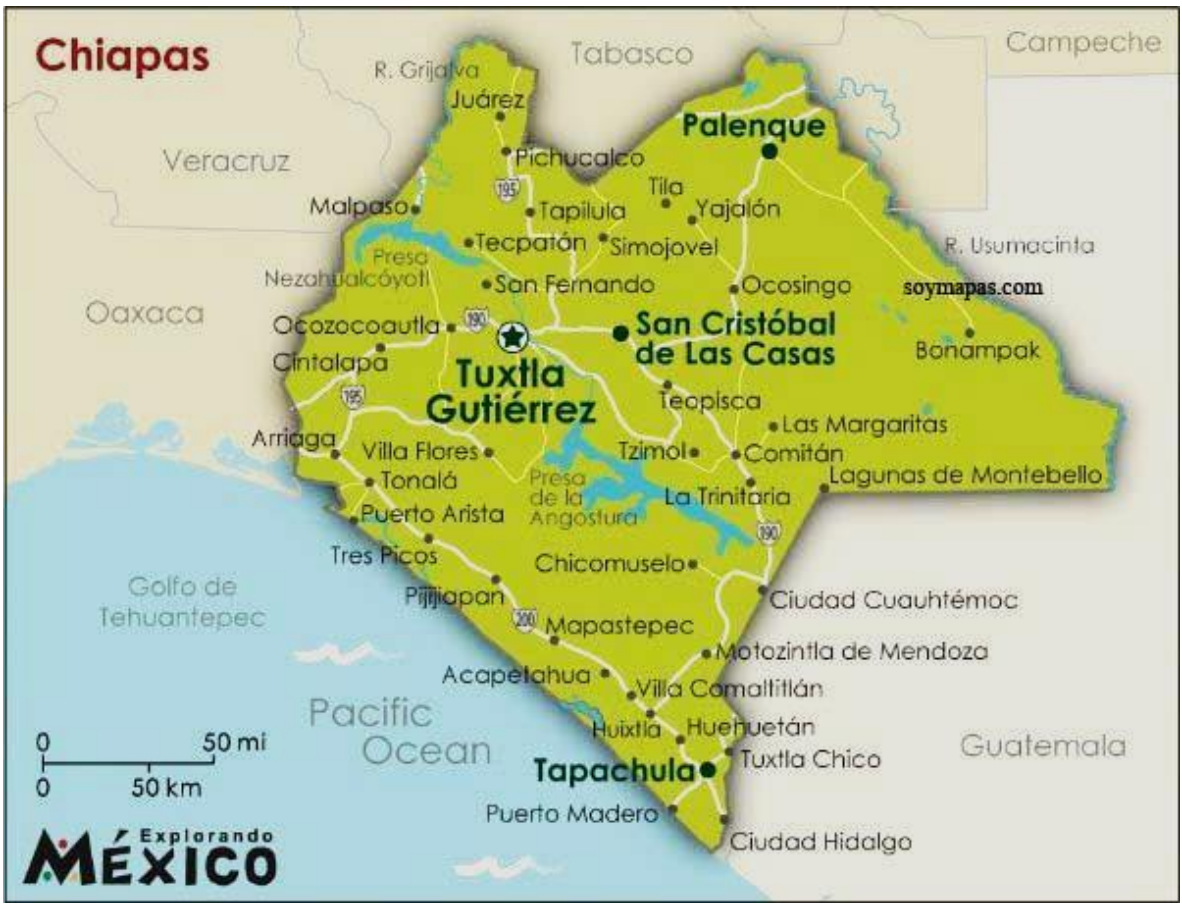

Mapa 2. Centroamérica

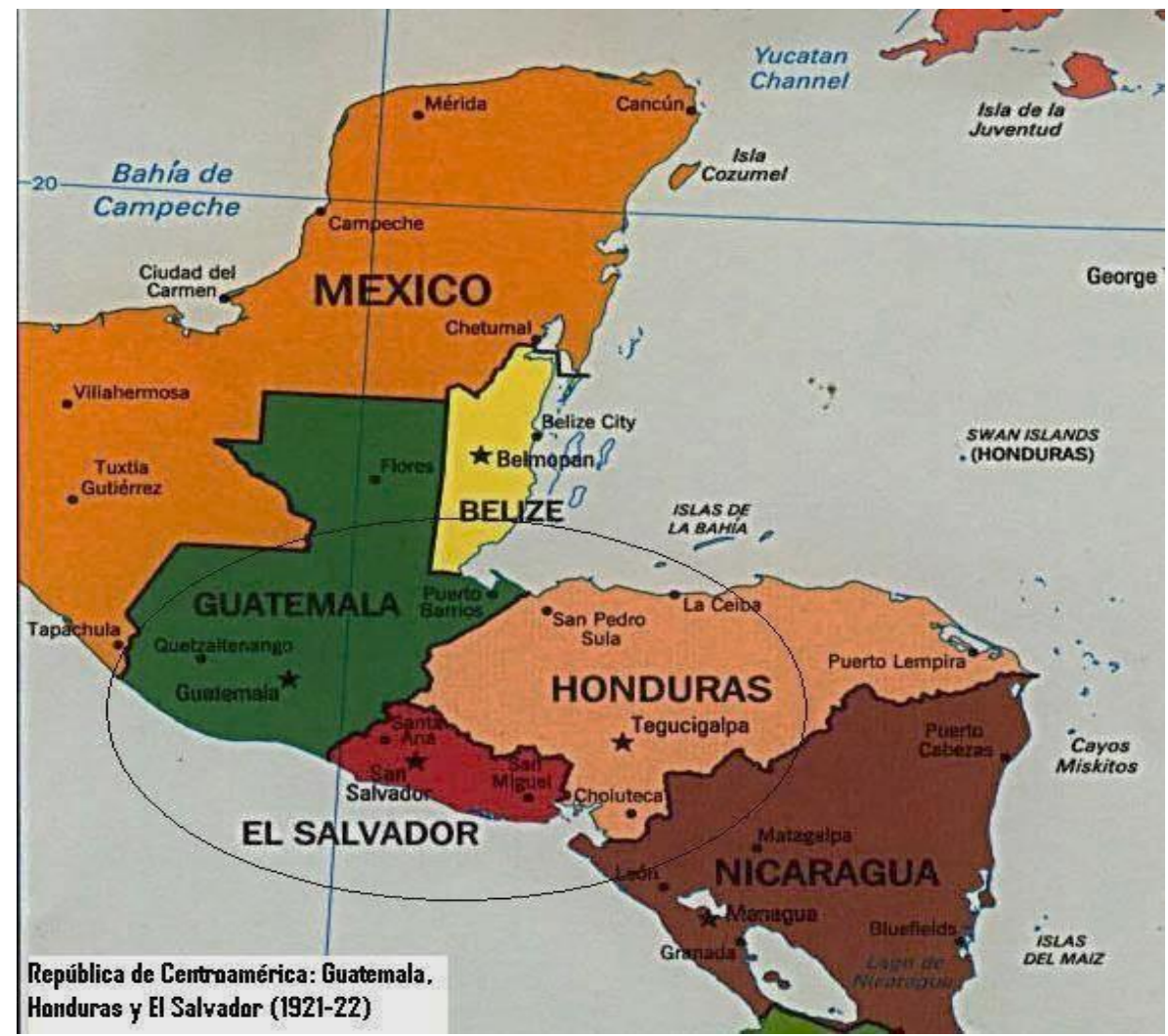




\section{Harriet $^{103}$}

Ocurre a mediados del siglo diecinueve.

Se fuga. Harriet Tubman se lleva de recuerdo las cicatrices en la espalda y una hendidura en el cráneo.

Al marido no se lo lleva. Él prefiere seguir siendo esclavo y padre de esclavos:

-Estás loca- le dice. Podrás escaparte, pero no podrás contarlo.

Ella se escapa, lo cuenta, regresa, se lleva a sus padres, vuelve a regresar y se lleva a sus hermanos. Y hace diecinueve viajes desde las plantaciones del sur hasta las tierras del norte, y atravesando la noche, de noche en noche, libera a más de trescientos negros.

Ninguno de sus fugitivos ha sido capturado. Dicen que Harriet resuelve con un tiro los agotamientos y los arrepentimientos que ocurren a medio camino. Y dicen que ella dice:

- $\quad$ A mí no se me pierde ningún pasajero.

Es la cabeza más cara de su tiempo. Cuarenta mil dólares fuertes se ofrecen en recompensa. Nadie los cobra.

Sus disfraces de teatro la hacen irreconocible y ningún cazador puede competir con su maestría en el arte de despistar pistas y de inventar caminos.

${ }^{103}$ Eduardo Galeano, Mujeres (México: siglo veintiuno editores, 2015), 66. 